\title{
Mycochemicals in wild and cultivated mushrooms: nutrition and health
}

\author{
Francesca Cateni (i) - Maria Letizia Gargano $(1)$ - Giuseppe Procida $(1)$ \\ Giuseppe Venturella (D) - Fortunato Cirlincione (D) - Valeria Ferraro $($ D
}
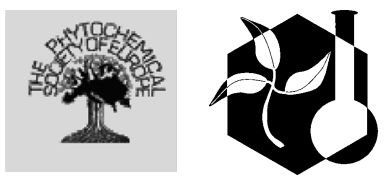

Received: 26 November 2020/Accepted: 18 February 2021 / Published online: 21 March 2021

(C) The Author(s) 2021

\begin{abstract}
The mushrooms have contributed to the development of active ingredients of fundamental importance in the field of pharmaceutical chemistry as well as of important tools in human and animal health, nutrition, and functional food. This review considers studies on the beneficial effects of medicinal mushrooms on the nutrition and health of humans and farm animals. An overview of the chemical structure and composition of mycochemicals is presented in this
\end{abstract}

F. Cateni - G. Procida

Department of Chemical and Pharmaceutical Sciences, University of Trieste, Piazzale Europa, 1, 34127 Trieste, Italy

e-mail: cateni@units.it

G. Procida

e-mail: gprocida@units.it

M. L. Gargano ( $\square)$

Department of Agricultural and Environmental Science, University of Bari Aldo Moro, Via Amendola 165/A,

70126 Bari, Italy

e-mail: marialetizia.gargano@uniba.it

G. Venturella · F. Cirlincione · V. Ferraro

Department of Agricultural, Food and Forest Sciences, University of Palermo, Viale delle Scienze, Bld. 5,

90128 Palermo, Italy

e-mail: giuseppe.venturella@unipa.it

F. Cirlincione

e-mail: fortunato.cirlincione@unipa.it

V. Ferraro

e-mail: valeria.ferraro@unipa.it review with particular reference to phenolic compounds, triterpenoids and sterols, fatty acids and lipids, polysaccharides, proteins, peptides, and lectins. The nutritional value and chemical composition of wild and cultivated mushrooms in Italy is also the subject of this review which also deals with mushrooms as nutraceuticals and the use of mushrooms in functional foods. The nutraceutical benefits of UV irradiation of cultivated species of basidiomycetes to generate high amounts of vitamin D2 is also highlighted and the ability of the muhsrooms to inhibit glycation is analyzed. Finally, attention is paid to studies on bioactivities of some Italian wild and cultivated mushrooms with particular reference to species belonging to the genus Pleurotus. The review highlights the potential of medicinal mushrooms in the production of mycochemicals that represent a source of drugs, nutraceutical, and functional food. 


\section{Graphic abstract}
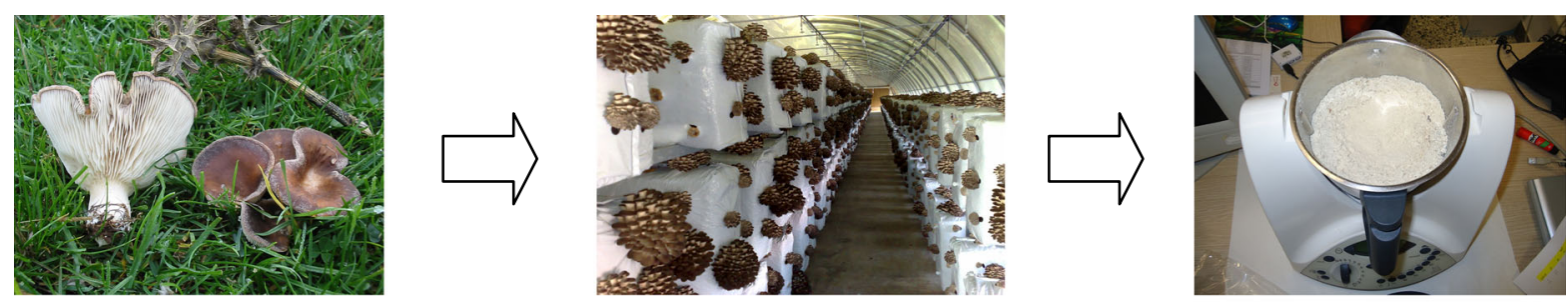

\begin{tabular}{lcccccccc}
\hline Sample & $\begin{array}{c}\text { Molecular Weight } \\
(\mathbf{k D a})\end{array}$ & \multicolumn{6}{c}{ Monosaccharide Composition (\%) } \\
\cline { 3 - 8 } & & Glc & Rham & Gal & Xyl & Ara & Man & Fru \\
\hline PEPS-A & - & 94.8 & - & - & - & - & 5.2 & - \\
PEPS-B & - & 60.8 & - & - & - & - & 3.0 & 36.2 \\
PEPS-A.1 & 68 & 100 & - & - & - & - & - & - \\
PEPS-A.2 & 43 & 100 & - & - & - & - & - & - \\
\hline
\end{tabular}

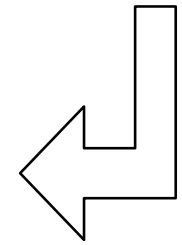

'Individual components were identified by comparison with standard sugars.

'Not detected.

Keywords Fungal diversity - Cultivation .

Mycochemicals $\cdot$ Chemical structures $\cdot$ Nutrition

\section{Abbreviations}

AGLs

BEPF

BRMs

CBAEP

COSY

FAB-MS

FAME

FIP

FT-IR

GC

GLC-MS

GLS

GSH

HBA

HCA

HIV

HMBC

HMG-CoA

HMQC

HPLC-MS
Acidic glycosphingolipids

Boletus edulis Polysaccharides

Biological response modifiers

Cibacron blue affinity-purified protein

Correlation spectroscopy

Fast atom bombardment

Fatty acid methyl esters

Immunomodulatory proteins

Fourier-transformed infrared

spectroscopy

Gas chromatography

Gas-liquid chromatography-mass

spectrometry

Glycosphingolipids

Glutathione peroxidase

Hydroxybenzoic acid

Hydroxycinnamic acid

Human immunodeficiency viruses

Heteronuclear multiple bond coherence

$\beta$-Hydroxy $\beta$-methylglutaryl-CoA

Heteronuclear multiple quantum

coherence

Liquid chromatography-mass

spectrometry
HS-ITEX/ Head Space "In Tube Extraction"

GC-MS Technique and gas chromatography

IEC Ion-exchange chromatography

iNKT Invariant natural killer cell

LCB Long-chain base

LDG-M Lactarius deliciosus Polysaccharides

MHS-SPME Multiple headspace-solid phase microextraction

MIC Minimum inhibitory concentration

MM Medicinal mushrooms

MUFA Monounsatured fatty acid

NMR Nuclear magnetic resonance

NOESY Nuclear overhauser effect

spectroscopy

OMW Olive mill wastewaters

PELPS Pleurotus eryngii var. elaeoselini polysaccharides

PEPE Pleurotus eryngii Purified

polysaccharides

PSK Polysaccharide K

PSP Polysaccharide peptide

PUFA Polyunsaturated fatty acid

ROESY Rotating-frame nuclear overhauser

effect correlation spectroscopy

RVP Russula virescens Polysaccharide

SEC Size-exclusion chromatograpy

SFA Saturated fatty acid

SPG Schizophyllan

TLC Thin layer chromatography

TOCSY Total correlation spectroscopy 
TPC

Total phenolic content

VOC

Volatile organic compounds

\section{Introduction}

Definition of mycochemicals

For millennia, mushrooms were well known as a nutritional and pharmaceutical resource especially in traditional oriental therapies, but after the discovery of Penicillin (Fleming 1929), they became a prominent source of natural antibiotics and other bioactive compounds.

The subject of mycochemistry, has developed as a distinct discipline that is concerned with the enormous variety of chemical substances, named "mycochemicals", elaborated and accumulated by mushrooms. It deals with the isolation and structure elucidation of the chemical structures of these substances, their biosynthesis, metabolism, turnover, their natural distribution, and their biological properties (Dewick 2009).

The mycochemicals play an important role in human and animals health, nutrition, and as functional food (Scheme 1).

Obviously, in all these applications, methods are needed for separation, and identification of the many different mycochemicals present in mushrooms. Thus, advances in our understanding of mycochemistry are directly related to the application of known techniques together with the continuing development of new analytical techniques to solve outstanding problems as they appear (Ruthes et al. 2015).

The characterization of mycochemicals is carried out using one or other, or a combination, of different chromatographic techniques that include thin layer chromatography (TLC), gas and/or liquid chromatography (CC, GC, HPLC). FT-IR, mass spectrometry and NMR experiments $\left[1 \mathrm{D}{ }^{1} \mathrm{H},{ }^{13} \mathrm{C}\right.$ NMR and $2 \mathrm{D}$ NMR (H-H COSY, TOCSY, HMQC, HMBC and NOESY)] are useful in providing information for the mycochemical structural elucidation.

\section{Beneficial effects of mushrooms on human and animals health and their nutrition}

The use of mushrooms in Chinese folk medicine and the Eastern countries has been known for a long time while only in recent decades, especially in Europe, there has been interesting in studies on their effects on human health (Wasser 2014; Gründemann et al. 2020). Moreover, the consumer's attention is increasingly shifting to the role that adding mushrooms to the diet can promote health and prevent the risk of disease, thanks to the effects of bioactive compounds on the human body.

In Asian countries, mushrooms have always been a primary source of food and medicine, due to the benefits they bring to physical well-being in general and the preventive and curative effects on various diseases such as cancer, cardiovascular diseases,

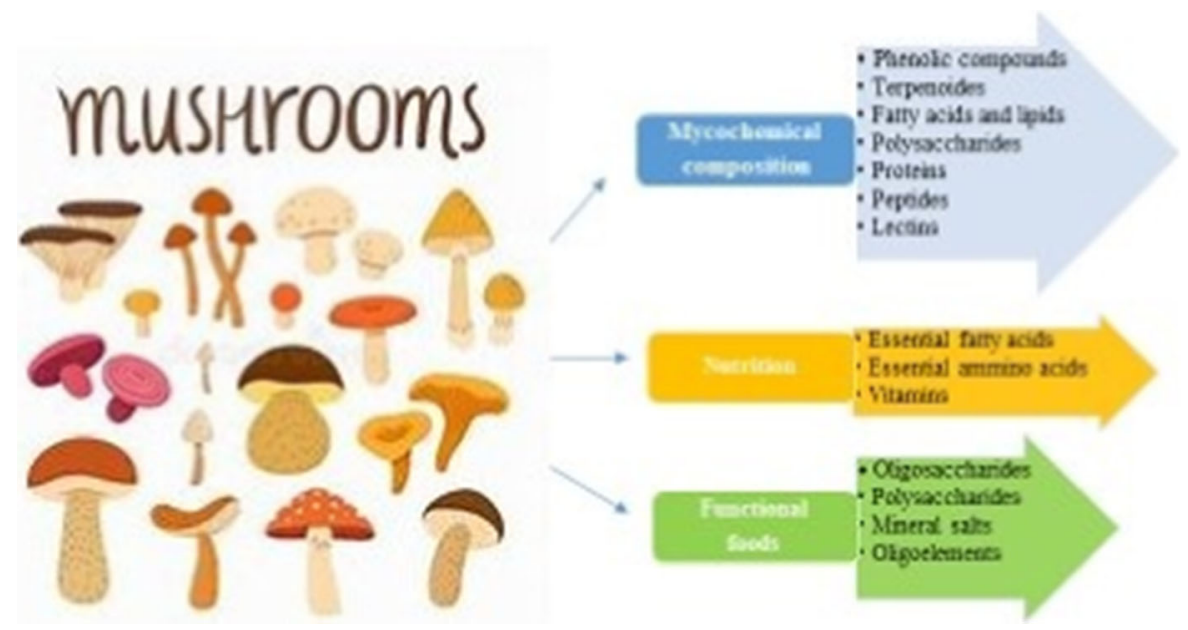

Scheme 1 The role of mycochemicals. Partially modified from www.dreamstime.com 
hypertension, neuropathies, etc. Numerous studies carried out in Asian countries, and more recently also in Europe, have demonstrated the multiple effects that the different chemical components of mushrooms have on the organism, not only humans but also animals. As reported by Fernandes et al. (2015) and Cheung (2013), dietary fiber of mushrooms helps to prevent constipation, hemorrhoids, colon diseases, diabetes, and cardiovascular diseases, improves intestinal tract function and insulin and cholesterol metabolism. It also strengthens the immune system and has anti-tumor activity. But the bioactive compounds in mushrooms are numerous and varied, as well as their possible uses. Wasser (2014) suggested medicinal mushroom drugs (MM drugs) in immunosuppressed patients.

The antitumor MM drugs, called biological response modifiers (BRMs), are used in different types of cancer and patients undergoing chemo- and radiotherapy, improving their quality of life as they reduce side effects and help overcome cancer growth. To date, several MM products have been developed for therapeutic and commercial purposes, especially from species widespread and used in the East. The most important polysaccharides which characterize mushroom extracts are Lentinan, isolated from Lentinula edodes (Berk.) Pegler, Schizopyllan (Sonifilan, Sizofiran, or SPG) from Schizophyllum commune Fr., Ganoderan from Ganoderma lucidum (Curtis) P. Karst., Krestin (PSK), and PSP (polysaccharide peptide) from Trametes versicolor (L.) Lloyd, Grifolan from Grifola frondosa (Dicks.) Gray, Befungin from Inonotus obliquus (Fr.) Pilát, and Imunoglukan $\mathrm{P} 4 \mathrm{H}$ (pleuran) from Pleurotus ostreatus (Jacq.) P. Kumm. (Giavasis 2014; Wasser 2014).

The daily intake of MM as part of a healthy diet also produces beneficial effects. Food supplements such as fruit bodies powders and extracts; biomass or extracts from mycelium harvested from a submerged liquid culture in fermentation tanks or bioreactors; dried and pulverized preparations of the combined substrate, mycelium, and mushroom primordial; spores and their extracts; dried mushrooms in tablets or pills are available on the market (Wasser 2014; Reis et al. 2017).

Mushroom bioactive compounds have an enormous potential for use as performance-enhancing natural additives for livestock animals. A survey, carried out by Bonanno et al. (2019), reveals how the integration in the diet of dairy ewes of mushroom myceliated grains (a mixing of L. edodes, Cordyceps spp., G. lucidum, P. ostreatus) improves production both in terms of quantity, with a higher milk yield, and quality (less intense yellow colour of cheese, lower secondary lipid oxidation, greater oxidative stability and antioxidant content of the cheese). BederskaŁojewska et al. (2017) showed how adding edible Basidiomycetes to feed improves the productive and physiological performance of broiler chickens and laying hen. Considerable benefits are also obtained from by-products of mushroom production, which are also rich in interesting bioactive compounds for the production of beneficial animal feed, fertilizers, cosmetics, and cosmeceuticals. (He et al. 2016; Taofiq et al. 2016; Antunes et al. 2020).

\section{Mycochemicals structures and composition}

Several mycochemicals are present in mushrooms with different chemical structures and composition such as phenolic compounds, terpenoids, lipids, polysaccharides and proteins, which are easily separated from other constituents by their high molecular weights.

Phenolic compounds

The term 'phenolic compounds' includes a wide range of mycochemicals that are characterized by an aromatic ring bearing one or more hydroxyl groups. Phenolic substances are water-soluble since they most frequently occur in combination with sugar as glycosides, but also as esters and polymers. These compounds belong to different classes based on the number of phenol rings and of the functional groups linked to these moieties. Thus, a classification comprises simple phenols, phenolic acids, phenylpropanoids, flavonoids, flavonols, flavones, stilbenes, and lignans.

Phenolic acids are the main phenolic substances found in mushrooms (Ferreira et al. 2009); they are classified into two groups; hydroxybenzoic acid (HBA) and hydroxycinnamic acid (HCA). Hydroxybenzoic acid derivatives are in the bound form and are part of more complex structures as hydrolyzable tannins, lignins, sugars and organic acids. Hydroxycinnamic acid derivatives are also present mainly in 
the bound form, attached to cell-wall structural elements, such as lignin, cellulose, proteins or linked to organic acids, through ester bonds, such as quinic or tartaric acids (Manach et al. 2004). The most widespread are the HCAs, which are useful not only as providing the building blocks of lignin but also concerning disease resistance and growth regulation. Five HCAs are common, in fact almost ubiquitous in mushrooms: ferulic, sinapic, caffeic, and $p$-/o-coumaric acids. HCAs usually are present in mushrooms in combined form as esters; and they are obtained in best yield by mild alkaline hydrolysis, since with hot acid hydrolysis material is lost for the decarboxylation to the corresponding hydroxystirenes.

Caffeic acid occurs in mushrooms regularly as a quinic acid ester (3-o-caffeoylquinic, 4-o-caffeoylquinic, 5-o-caffeoylquinic). Besides, tannic and ellagic acids are observed (Ferreira et al. 2009). In mushrooms, the most prevalent HBAs derivatives are reported to be gallic, protocatechuic, gentisic, homogentisic, p-hydroxybenzoic, 5-sulphosalicylic, syringic, veratric, vanillic (Ferreira et al. 2009) (Table 1).

HBA and HCA compounds are derived biosynthetically from the shikimate pathway. L-phenylalanine and -tyrosine are the crucial amino acids and the building blocks in this pathway.

Flavonoids are another large group of naturally occurring phenolic compounds that are all structurally derived from the parent substance flavone consisting of two benzene rings (A and B) combined with a pyran one (C). Different classes of flavonoids are recognized, such as anthocyanidins, flavonols, flavones, isoflavones, flavanones, and flavonols (Manach et al. 2004). The flavonoids are present in nature as glycosides or aglycones.

It was reported that mushrooms do not synthesize flavonoids, however, the presence of flavonoids was found in various edible mushrooms, e.g. catechin, myricetin, chrysin, hesperetin, naringenin, naringin, formometin, biochanin, resveratrol, quercetin, pyrogallol, rutin, and kaempferol (Gil-Ramirez et al. 2016; Ferreira et al. 2009).

Phenolic acids and flavonoids identification and quantification from some selected mushrooms $[P$. ostreatus, P. eryngii (DC.) Quél., Agaricus bisporus (J.E. Lange) Imbach, Cyclocybe aegerita (V. Brig.) Vizzini, Russula cyanoxantha (Schaeff.) Fr., $R$. virescens (Schaeff.) Fr., Macrolepiota procera
(Scop.) Singer, Boletus edulis Bull., Lactarius deliciosus (L.) Gray, Coprinus comatus (O.F. Müll.) Pers., Tuber melanosporum Vittad.] were done by highperformance liquid chromatography coupled with mass spectrometry (HPLC-MS) (Table 1). The compounds identification derives from their retention times, their UV-Vis absorption spectra and mass spectra data and also by comparison with available data (Fogarasi et al. 2018). 4-Hydroxybenzoic acid and 5-feruloylquinic acid were found to be the major compounds in $P$. ostreatus and A. bisporus with concentrations of $75.042 \mathrm{mg} / 100 \mathrm{~g} \cdot \mathrm{fw}$ and $35.040 \mathrm{mg} / 100 \mathrm{~g} \cdot \mathrm{fw}$ for $P$. ostreatus and $79.50 \mathrm{mg} /$ $100 \mathrm{~g} \cdot \mathrm{fw}$ and $71.01 \mathrm{mg} / 100 \mathrm{~g} \cdot \mathrm{fw}$ for A. bisporus, respectively. B. edulis extract is characterized by high concentrations of cinnamic acid $168.614 \mathrm{mg} / 100 \mathrm{~g} \cdot \mathrm{fw}$ and catechin $145.566 \mathrm{mg} / 100 \mathrm{~g} \cdot \mathrm{fw}$ (Fogarasi et al. 2018). Hasnat et al. (2014) reported content of phenolic compounds for $R$. virescens of 8.74 and $2.21 \mathrm{mg}$ gallic acid/100 g.fw, and flavonoid compounds were 2.83 and $1.02 \mathrm{mg}$ catechin/100 g.fw for the water and ethanol extracts, respectively.

Among phenolic acids, the major amount of protacatechuic acid was found in $M$. procera (5.19 mg/Kg DW) (Nowacka et al. 2014). Kalogeropoulos et al. evaluated the content of individual phenolic compounds for $L$. deliciosus; $p$-OH-benzoic acid $(24.5 \mu \mathrm{g} / 100 \mathrm{~g} \mathrm{fw})$ and $p$-OH-phenylacetic acid $(18.3 \mu \mathrm{g} / 100 \mathrm{~g} \mathrm{fw})$ were the more abundant among the hydroxyl-benzoic acids, $o$-coumaric acid $(30.2 \mu \mathrm{g} /$ $100 \mathrm{~g} \mathrm{fw}$ ) among the hydroxycinnamic acids, and chrysin $(16.5 \mu \mathrm{g} / 100 \mathrm{~g} \mathrm{fw})$ among the flavonoids.

As concerns $C$. comatus, among the phenolic compounds, the highest content was detected for quinic acid $(14.6 \mathrm{mg} / 100 \mathrm{~g} \mathrm{dw})$ and quercetin (3.01 mg/100 g fw), where the lowest amount was detected for the isoflavonoids genistein $(0.023 \mathrm{mg} /$ $100 \mathrm{~g} \mathrm{dw})$ and daidzein $(0.061 \mathrm{mg} / 100 \mathrm{~g} \mathrm{dw})$ (Nowakowski et al. 2020). Besides, Comatin (4, 5-Dihydroxy-2-methoxy-benzaldehyde) isolated and identified from $C$. comatus has shown hypoglycaemic properties on alloxan-induced-diabetic rats (Ding et al. 2010) (Table1).

In the literature, it is common to find the total phenolic content (TPC) found in mushrooms methanolic extract by the Folin-Ciocalteu assay. However, this assay has some limitations since other readily oxidized compounds such as amino acids, ascorbic acid, and 
sugars could interfere overestimating the total pheno-

lic content (Arbaayah and Umi 2013).

Phenolic compounds possess antioxidant properties

to scavenge free radicals, to prevent lipid peroxidation, and to chelate ferrous ions (Kumar and Pandey 2013).

Table 1 Phenolic compounds of some selected mushrooms species

\begin{tabular}{|c|c|c|}
\hline $\begin{array}{l}\text { Mushroom } \\
\text { species }\end{array}$ & Phenolic compounds & References \\
\hline $\begin{array}{l}\text { Pleurotus } \\
\text { ostreatus }\end{array}$ & $\begin{array}{l}\text { 4-HBA, 2,4-dihydroxybenzoic acid, 4-hydroxy phenylacetic } \\
\text { acid, pirocatechuic acid, protocatechuic acid, catechin, } \\
\text { gallocatechin, } o \text {-coumaric acid, cinnamic acid, } \\
\text { 5-feruloylquinic acid, 3,5-dicaffeoylquinic acid, chlorogenic } \\
\text { acid, syringic acid, vanillic acid, caffeic acid, ferulic acid, 2,6- } \\
\text { dimethoxyphenol }\end{array}$ & $\begin{array}{l}\text { Sarma et al. (2018), Fogarasi et al. (2018), } \\
\text { Koutrotsios et al. (2017) and Palacios et al. } \\
\text { (2011) }\end{array}$ \\
\hline $\begin{array}{c}\text { Pleurotus } \\
\text { eryngii }\end{array}$ & $\begin{array}{l}\text { 4-HBA, } p \text {-coumaric acid, cinnamic acid, protocatechuic acid, } \\
\text { gallic acid, phenol }\end{array}$ & Souilem et al. (2017) and Reis et al. (2012) \\
\hline $\begin{array}{l}\text { Pleurotus } \\
\text { cornucopiae }\end{array}$ & $\begin{array}{l}\text { Gallic acid, protocatechuic acid, chlorogenic acid, vanillin, } \\
\text { ferulic acid, naringin, naringenin, hesperitin, formononetin, } \\
\text { biochanin-A }\end{array}$ & Nuhu et al. (2011) \\
\hline $\begin{array}{l}\text { Agaricus } \\
\text { bisporus }\end{array}$ & $\begin{array}{l}\text { 4-HBA, 2,4-dihydroxybenzoic acid, 4-hydroxy phenylacetic } \\
\text { acid, protocatechuic acid, catechin, gallocatechin, } p \text { - } \\
\text { hydroxybenzaldehyde, } p \text {-aminophenol, catechol, coumaric } \\
\text { acid, cinnamic acid, 4- and 5-feruloylquinic acid, 3,5- } \\
\text { dicaffeoylquinic acid }\end{array}$ & $\begin{array}{l}\text { Weijn et al. (2013), Fogarasi et al. (2018), } \\
\text { Palacios et al. (2011) }\end{array}$ \\
\hline $\begin{array}{r}\text { Cyclocybe } \\
\text { aegerita }\end{array}$ & $\begin{array}{l}\text { Protocatechuic acid, 4-HBA, chlorogenic acid, gallic acid, } \\
\text { caffeic acid, vanillic acid, } p \text {-coumaric acid, ferulic acid, } \\
\text { sinapic acid, } t \text {-cinnamic acid, rutin, quercetin, kaempferol }\end{array}$ & Gasecka et al. (2016) \\
\hline $\begin{array}{l}\text { Russula } \\
\quad \text { cyanoxantha }\end{array}$ & Quercetin, quercetin-3-o-rutinoside, catechin, epicatechin & Butkhup et al. (2018) \\
\hline $\begin{array}{l}\text { Russula } \\
\text { virescens }\end{array}$ & $\begin{array}{l}\text { Catechin, ferulic acid, kaempferol, luteolin, vanillic acid, } \\
\text { apigenin }\end{array}$ & Hasnat et al. (2014) \\
\hline $\begin{array}{l}\text { Macrolepiota } \\
\text { procera }\end{array}$ & Protocatechuic acid & Nowacka et al. (2014) \\
\hline Boletus edulis & $\begin{array}{l}\text { 4-HBA, 2,4-dihydroxybenzoic acid, gallic acid, 4-hydroxy } \\
\text { phenylacetic acid, protocatechuic acid, caffeic acid, catechin, } \\
\text { chlorogenic acid, gallocatechin, } p \text {-coumaric acid, sinapic acid, } \\
o \text {-coumaric acid, cinnamic acid, 3,5-dicaffeoylquinic acid, } \\
\text { gentisinic acid, homogentisinic acid, myricetin, protocatechuic } \\
\text { acid }\end{array}$ & Fogarasi et al. (2018) and Palacios et al. (2011) \\
\hline $\begin{array}{l}\text { Lactarius } \\
\text { deliciosus }\end{array}$ & $\begin{array}{l}\text { 4-HBA, 4-hydroxy phenylacetic acid, 3,4-dihydroxy } \\
\text { phenylacetic acid, syringic acid, vanillic acid, caffeic acid, } \\
\text { cinnamic acid, chlorogenic acid, ferulic acid, o-coumaric acid, } \\
\text { p-coumaric acid, tyrosol, vanillin, chrysin, kaempferol, } \\
\text { resveratrol, gallic acid, gentisinic acid, homogentisinic acid, } \\
\text { myricetin, protocatechuic acid, pyrogallol }\end{array}$ & $\begin{array}{l}\text { Kalogeropoulos et al. (2013) and Palacios } \\
\text { et al. (2011) }\end{array}$ \\
\hline $\begin{array}{l}\text { Coprinus } \\
\text { comatus }\end{array}$ & $\begin{array}{l}\text { Flavones, flavonols, flavanones, flavanols, biflavonoids, } \\
\text { isoflavonoids, hydroxybenzoic acids, hydroxycinnamic acids, } \\
\text { coumarins, chlorogenic acids }\end{array}$ & $\begin{array}{l}\text { Nowakowski et al. (2020) and Cayan et al. } \\
\text { (2018) }\end{array}$ \\
\hline & 4,5-Dihydroxy-2-methoxy-benzaldehyde (comatin) & Ding et al. (2010) \\
\hline \multirow{2}{*}{$\begin{array}{l}\text { Tuber } \\
\quad \text { melanosporum }\end{array}$} & Homogentisic acid, 4-HBA, 3,4-dihydroxybenzaldehyde & Villares et al. (2012) \\
\hline & Flavonoids, phenols & Li et al. (2019) \\
\hline
\end{tabular}


Terpenoids

The general term 'terpenoid' includes all such substances with a common biosynthetic origin. Terpenoids arise from the isoprene molecule $\mathrm{CH}_{2}=\mathrm{C}\left(\mathrm{CH}_{3}\right)-\mathrm{CH}=\mathrm{CH}_{2}$ and their carbon skeletons originate from the union of two or more of these C5 units. Their classification is according to whether they contain two $\left(\mathrm{C}_{10}\right)$, three $\left(\mathrm{C}_{15}\right)$, four $\left(\mathrm{C}_{20}\right)$, six $\left(\mathrm{C}_{30}\right)$, or eight $\left(\mathrm{C}_{40}\right)$ such unit. Essential oils, volatile monoand sesquiterpenes $\left(\mathrm{C}_{10}\right.$ and $\left.\mathrm{C}_{15}\right)$, including the less volatile diterpenes $\left(\mathrm{C}_{20}\right)$, the involatile triterpenoids and sterols $\left(\mathrm{C}_{30}\right)$, and the carotenoids pigments $\left(\mathrm{C}_{40}\right)$ are terpenoids. Each of these different classes of terpenoid is of importance in mushroom growth, metabolism, or ecology (Dewick 2009).

Chemically, terpenoids are generally lipid-soluble and are extracted from mushrooms with dichloromethane, light petroleum, or ether and can be separated by flash chromatography on silica gel or alumina using some solvents. Isomerism and the presence of different geometric conformations are common among terpenoids. It depends on the substitution around the cyclohexane ring, twisted in the so-called 'chair' form. The stereochemistry of the cyclic terpenoids is highly involved. During purification procedures, structural re-arrangement and isomerization may occur and lead to artifact formation.

Essential oils.

The mainly terpenoid essential oils include the volatile fraction responsible for the characteristic odor and scent found in many mushrooms. They are commercially important as the basis of skincare in cosmetics and flavorings in the food industry. Fogarasi et al. (2018) reported the presence of $\alpha$-pinene, $\beta$ phellandrene, $\beta$-pinene, $\beta$-myrcene, and D-limonene in $A$. bisporus and B. edulis as main terpenoids. The intube extraction headspace coupled with gas chromatography-mass spectrometry (HS-ITEX/GC-MS) permits to obtain the volatile profile of selected mushrooms. The volatile constituents strongly influence the aroma profile of each mushroom variety.

Triterpenoids and sterols

Triterpenoids are compounds with a carbon skeleton based on six isoprene units. They biosynthetically derived from squalene, an acyclic C10 hydrocarbon.
They have relatively complex cyclic structures, most being either alcohols, aldehydes, or carboxylic acids.

Sterols are triterpenes which are based on the cyclopentane perhydrophenantrene ring system. So, one example is ergosterol, ubiquitous in occurrence in mushrooms. Ergosterol is a component of the fungal cell membrane, which under the influence of UV irradiation is converted to vitamin $\mathrm{D}_{2}$. Besides, ergosterol shows several healthy beneficial properties such as antihyperlipidemic, anti-inflammatory, antioxidant and the effect for inhibiting fungi and bacteria growth (Koutrotsios et al. 2017).

All types of triterpenoids are isolated by very similar procedures, based mainly on column chromatography, GLC and TLC. Identities are confirmed by melting point, rotation, FT-IR, GLC-MS, and NMR experiments.

Table 2 includes the triterpenoids and sterols found in some selected mushroom species.

Different $P$. ostreatus strains were evaluated for their sterol composition. In all mushroom samples analyzed ergosterol dominated, comprising $51.9-87.4 \%$ of sterols, followed by its metabolites ergosta-7-enol (12.7\%), ergosta-5,7-dienol (7.6\%), and ergosta-7,22-dienol (6\%) (Koutrotsios et al. 2017). The ergosterol content in $P$. eryngii was reported as $20 \mathrm{mg} / 100 \mathrm{~g} \mathrm{dw}$, although a higher value was measured in commercial samples (Souilem et al. 2017). Kikuchi et al. (2017, 2018) reported the isolation and structure elucidation of ergostane type sterols and bisabolane-type sesquiterpenes from $P$. eryngii with aromatase and nitric oxide production inhibitory effects, respectively (Table 2 ).

Wang et al. (2013a) reported the identification of novel and rare perhydrobenzannulated 5,5-spiroketal sesquiterpenes, named pleurospiroketals A-E from the edible mushroom $P$. cornucopiae with inhibitory activity against nitric oxide production in lipopolysaccharide-activated macrophages with $\mathrm{IC}_{50}$ values between 6.8-20.8 $\mu \mathrm{M}$.

From $M$. procera were isolated and identified 12 lanostane-type triterpenoids characterized by the presence of a rare '1-en-1,11-epoxy' moiety, namely lepiotaprocerins A-L. Lepiotaprocerins A-F showed significant inhibitions of nitric oxide $(\mathrm{NO})$ production, while lepiotaprocerins G-L, showed cytotoxicity effects against different human cancer cell lines, and lepiotaprocerin I displayed antitubercular activity 
Table 2 Triterpenoids of some selected mushrooms species

\begin{tabular}{|c|c|c|}
\hline Mushrooms species & Triterpenoids & References \\
\hline Pleurotus ostreatus & $\begin{array}{l}\text { Ergosterol, ergosta-5,7-dienol, ergosta-7-enol, } \\
\text { ergosta-7,22-dienol, oleanolic acid, ursolic acid }\end{array}$ & Sarma et al. (2018) and Koutrotsios et al. (2017) \\
\hline \multirow[t]{5}{*}{ Pleurotus eryngii } & Ergosterol & Souilem et al. (2017) \\
\hline & Ergostane-type sterols & Kikuchi et al. (2017) \\
\hline & Strophasterols E and F & Kikuchi et al. (2019) \\
\hline & Bisabolane-type sesquiterpenes & Kikuchi et al. (2018) \\
\hline & Eryngiolide A, pentacyclic triterpenoids & Fu et al. (2016) \\
\hline \multirow[t]{4}{*}{ Pleurotus cornucopiae } & $\begin{array}{l}\text { Ergosterol, Ergosta-5,8,22-trien-3-ol, 5,6- } \\
\text { Dihydro-ergosterol, Ergosta-7-enol, Ergosta- } \\
\text { 7,22-dienol, Ergosta-14,22-dien-3-ol, } \\
\text { Campesterol }\end{array}$ & Parmar and Kumar (2015) \\
\hline & $\begin{array}{l}\text { Pleurospiroketals A-E, Perhydrobenzannulated } \\
\text { 5,5-spiroketal sesquiterpenes }\end{array}$ & Wang et al. (2013a) \\
\hline & Monoterpenoids, sesquiterpenoids & Wang et al. (2013b) \\
\hline & Ergostane-type sterols & Lee et al. (2017) \\
\hline \multirow[t]{2}{*}{ Agaricus bisporus } & Ergosterol & Alshammaaa (2017) \\
\hline & Terpenoid spiro ketals & Grothe et al. (2013) \\
\hline Cyclocybe aegerita & Bovistols A-C, Protoilludane Pasteurestin C & Surup et al. (2019) \\
\hline Russula cyanoxantha & Ergosta-4,6,8(14),22-tetraen-3-one & Zhao et al. (2011) \\
\hline Macrolepiota procera & Lanostane triterpenoids (Lepiotaprocerins A-L) & Chen et al. (2018) \\
\hline Boletus edulis & Botryane sesquiterpenoids (Boledulins A-C) & Feng et al. (2011) \\
\hline \multirow[t]{2}{*}{ Lactarius deliciosus } & $\begin{array}{l}\text { Ergosterol, Ergosta-5,7-dienol, Ergosta-7-enol, } \\
\text { Ergosta-7,22-dienol, Lanosterol, Lanosta-8,24- } \\
\text { dienol, } 4 \alpha \text {-Methylzymosterol }\end{array}$ & Kalogeropoulos et al. (2013) \\
\hline & Azulene-type sesquiterpenoids & Tala et al. (2017) \\
\hline Coprinus comatus & Terpenoids & Dulay et al. (2015) \\
\hline Tuber magnatum & $\begin{array}{l}\text { Ergosterol, Ergosta-7,22-dienol, Ergosta-5,8- } \\
\text { dien-3-ol, Brassicasterol, 5-Dihydroergosterol, } \\
\text { Campe-sterol, 24(28)-Dehydroergosterol, } \\
\text { Barrigenol R1, Fungisterol, Lanosterol, } \\
\text { Dehydroepiandrosterone }\end{array}$ & Tejedor-Calvo et al. (2020) and Yeh et al. (2016) \\
\hline Tuber melanosporum & $\begin{array}{l}\text { Ergosterol, Ergosta-7,22-dienol, Brassicasterol, } \\
\text { 5-Dihydroergosterol, Campesterol, 24(28)- } \\
\text { Dehydroergosterol, Barrigenol R1, Fungisterol, } \\
\text { Lanosterol, } \beta \text {-Sitosterol, } \\
\text { Dehydroepiandrosterone }\end{array}$ & Tejedor-Calvo et al. (2020) and Yeh et al. (2016) \\
\hline Tuber borchii & $\begin{array}{l}\text { Ergosterol, Ergosta-7,22-dienol, Brassicasterol, } \\
\text { Campesterol, 24(28)-Dehydroergosterol, } \\
\text { Dehydroepiandrosterone }\end{array}$ & Tejedor-Calvo et al. (2020) and Yeh et al. (2016) \\
\hline
\end{tabular}

against Mycobacterium tuberculosis H37Ra with a MIC of $50 \mu \mathrm{g} / \mathrm{mL}$ (Chen et al. 2018).

Three non-isoprenoid botryane sesquiterpenoids, named boledulins A-C were isolated from the cultures of $B$. edulis Bull. with moderate inhibitory activity against five human cancer cell lines (Feng et al. 2011), while from the edible mushroom $L$. deliciosus, azulene-type sesquiterpenoids were characterized (Tala et al. 2017).

Many sterols such as campesterol, lanosterol, brassicasterol, $\beta$-sitosterol, ergosterol were analyzed in the fruiting bodies of different Tuber species 
Fig. 1 Chemical structures of mushroom lipids
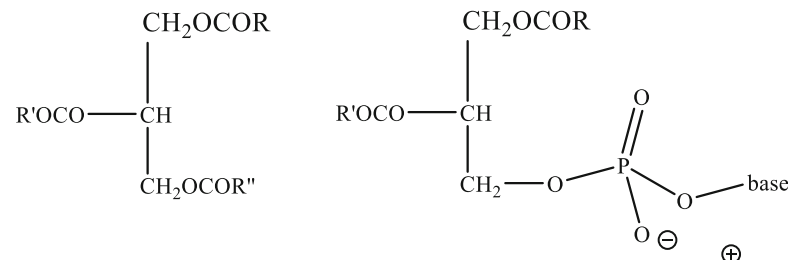

$\begin{aligned} \text { Base }= & \text { choline, }-\mathrm{CH}_{2} \mathrm{CH}_{2} \mathrm{NMe}_{3} \oplus \\ & \text { ethanolamine, }-\mathrm{CH}_{2} \mathrm{CH}_{2} \mathrm{NH}_{3} \\ & \text { serine, }-\mathrm{CH}_{2} \mathrm{CH}\left(\mathrm{NH}_{2}\right) \mathrm{CO}_{2} \mathrm{H}\end{aligned}$

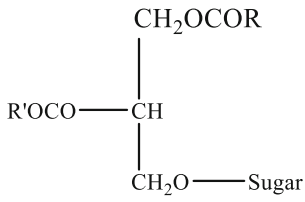

Sugar $=$ glucose galactose

( R, R', R" = Hydrocarbon chains of different fatty acids)

(Table 2). The main sterols found in Tuber magnatum Picco and T. melanosporum fruiting bodies were ergosterol and brassicasterol, which amounted to $63.1-66.7 \%$ and $15.7-21.3 \%$ of the total sterols, respectively. Also the mycelia of $T$. borchii Vittad. are a rich source of ergosterol (90.3\%). The complex composition profile of the truffle sterols might be taken as the fingerprint for the identification of the truffle species (Yeh et al. 2016).

Fatty acids and lipids

Mushrooms are an essential source of fatty acids that occur mainly in bound form, esterified to glycerol, as fats or lipids. They are crucial as membrane constituents in the mitochondria and chloroplasts and provide mushrooms with a storage form of energy. The content of total lipids ranges mostly from 1 to $4 \%$ of the dry weight. Besides, mushroom fats are rich in unsaturated fatty acids (PUFA) and particularly in linoleic acid (Koutrotsios et al. 2017).

Lipids are known by their distinct solubility properties and are extracted with alcohol, ether or dichloromethane from mushrooms.

The general structures for the three main classes of mushrooms lipids are reported in Fig. 1.

Structural variation within each class is due to the different fatty acid residues that may be present. The identification of lipids mainly requires the determination of their fatty acid components. Fatty acids are determined as methyl esters (FAMEs) after hot saponification of the sample, followed by reaction with $\mathrm{BF}_{3} / \mathrm{MeOH}$. The resulting FAMEs are analyzed by GC-MS by comparison with standard FAMEs and confirmed utilizing mass spectra library (Helrich 1990).
In some selected mushrooms species, the fatty acid composition is characterized by a prevalence of

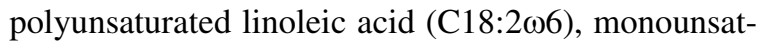
urated oleic acid (C18:1 $\omega 9)$, and saturated palmitic acid (C16:0) (Table 3). The fatty acids are divided into saturated (SFA), monounsaturated (MUFA), and polyunsaturated (PUFA). In particular, the ratio between the single components of PUFA is fundamental in preventing cardiovascular diseases. PUFAs are a family of so-called 'essential' fatty acids that are converted to tissue hormones useful to prevent blood clotting and hypertension (Pietrzak-Fiećko et al. 2016).

Koutrotsios et al. (2017) evaluated the fatty acid profile of different $P$. ostreatus strains, collected in Greece, including saturated fatty acids (SFA), monounsaturated fatty acids (MUFA), polyunsaturated fatty acids (PUFA), $\omega 3$ and $\omega 6$ fatty acids. PUFA was the major fatty acid class detected; linoleic acid

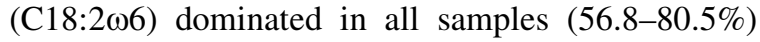

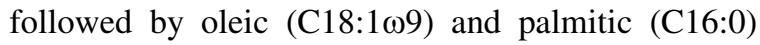
(6.3-19.5 and 7.5-12.1\%, respectively) (Table 3).

Jing et al. (2012) reported a selective method where fatty acids from cultivated mushrooms $P$. eryngii, $C$. aegerita and $C$. comatus were derivatized with BAETS as the labeling reagent and identified by high-performance liquid chromatography with fluorescence detection and online mass spectrometry (HPLC-FLD-MS/MS).

Total fatty acids (TFAs) values for P. eryngii, $C$. aegerita and $C$. comatus (dw) were $42.60,48.95$, and $79.21 \mathrm{mg} 10 \mathrm{~g}^{-1}$, respectively, while UFA:SFA ratio were $3.23,3.29$, and 3.03, respectively. Linoleic $(\mathrm{C} 18: 2 \omega 6)$ and oleic $(\mathrm{C} 18: 1 \omega 9)$ acids were the main FA found and their content was between 27.17-49.34 mg $10 \mathrm{~g}^{-1}$ and 4.08-22.15 mg $10 \mathrm{~g}^{-1}$, respectively. 
Table 3 Fatty acids of some selected mushrooms species

\begin{tabular}{|c|c|c|}
\hline $\begin{array}{l}\text { Mushrooms } \\
\text { species }\end{array}$ & Fatty acids & References \\
\hline $\begin{array}{l}\text { Pleurotus } \\
\text { ostreatus }\end{array}$ & SFA, MUFA, PUFA, $n-6, n-3$ & $\begin{array}{l}\text { Koutrotsios et al. (2017) and } \\
\text { Fogarasi et al. (2018) }\end{array}$ \\
\hline $\begin{array}{l}\text { Pleurotus } \\
\text { eryngii }\end{array}$ & 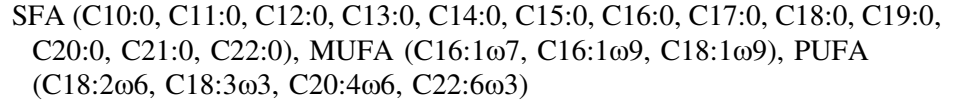 & $\begin{array}{l}\text { Jing et al. (2012) and Rodrigues } \\
\text { et al. (2015) }\end{array}$ \\
\hline $\begin{array}{l}\text { Pleurotus } \\
\text { cornucopiae }\end{array}$ & 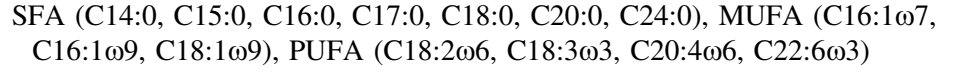 & Rodrigues et al. (2015) \\
\hline $\begin{array}{l}\text { Agaricus } \\
\text { bisporus }\end{array}$ & 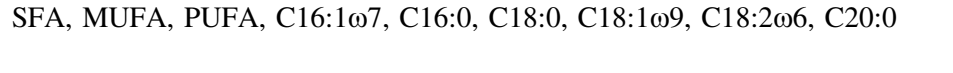 & $\begin{array}{l}\text { Sande et al. (2019) and Fogarasi } \\
\text { et al. (2018) }\end{array}$ \\
\hline $\begin{array}{r}\text { Cyclocybe } \\
\text { aegerita }\end{array}$ & 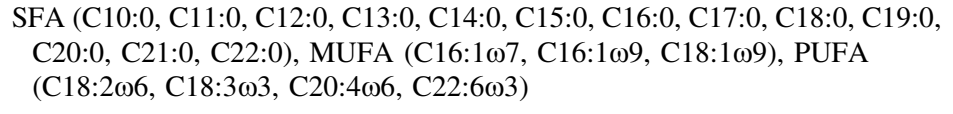 & Jing et al. (2012) \\
\hline $\begin{array}{l}\text { Russula } \\
\text { cyanoxantha }\end{array}$ & 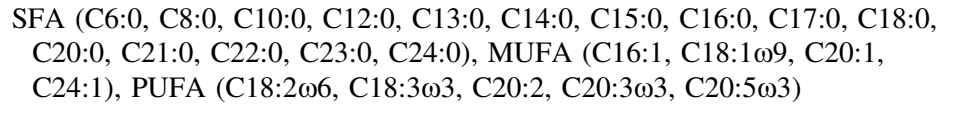 & Grangeia et al. (2011) \\
\hline $\begin{array}{l}\text { Russula } \\
\text { virescens }\end{array}$ & 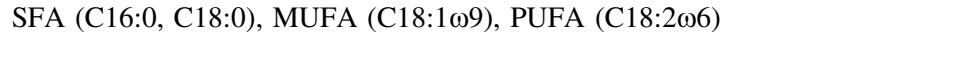 & Leal et al. (2013) \\
\hline $\begin{array}{l}\text { Macrolepiota } \\
\text { procera }\end{array}$ & 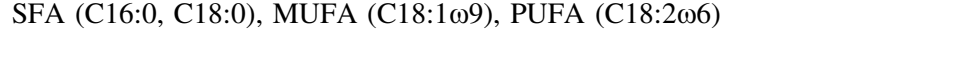 & Yilmaz et al. (2013) \\
\hline Boletus edulis & 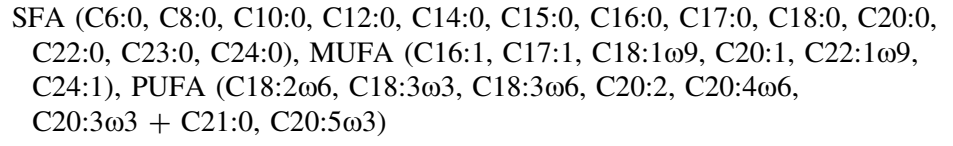 & $\begin{array}{l}\text { Heleno et al. (2011) and } \\
\text { Pietrzak-Fiećko et al. (2016) }\end{array}$ \\
\hline $\begin{array}{l}\text { Lactarius } \\
\text { deliciosus }\end{array}$ & 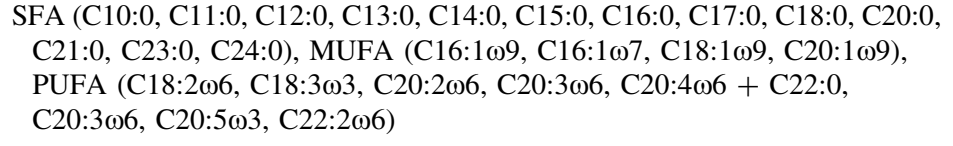 & $\begin{array}{l}\text { Kalogeropoulos et al. (2013) and } \\
\text { Ergönül et al. (2012) }\end{array}$ \\
\hline $\begin{array}{l}\text { Coprinus } \\
\text { comatus }\end{array}$ & 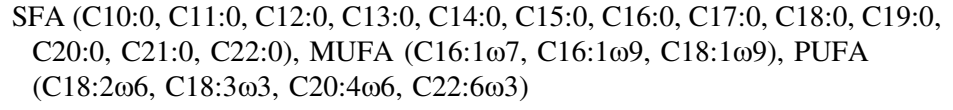 & $\begin{array}{l}\text { Jing et al. (2012) and Ergönül } \\
\text { et al. (2012) }\end{array}$ \\
\hline $\begin{array}{l}\text { Tuber } \\
\text { melanosporum }\end{array}$ & 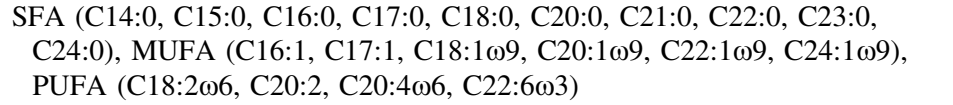 & Jiang et al. (2018) \\
\hline
\end{tabular}

SFA saturated fatty acids, MUFA monounsaturated fatty acids, $P U F A$ polyunsaturated fatty acids

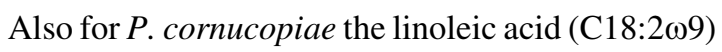
was the main FA, with a composition characterized by a higher content of mono (MUFA) and polyunsaturated FA (PUFA) than of saturated FA (SFA) (Rodrigues et al. 2015).

The lipids analyzed for A. bisporus showed a high content of unsaturated acids with linoleic acid $(\mathrm{C} 18: 2 \omega 6)$ as the main constituent of fruiting bodies $(33.3 \%)$ and stems (39.4\%). The total saturated fatty acid (SFA) content was between 22.1 and $26.5 \%$ of total lipids, palmitic acid (C16:0) was the major SFA at about $14 \%$ followed by stearic acid (C18:0) at about $4 \%$. Oleic acid (C18:1 $\omega 9)$ was the major monounsaturated fatty acid (MUFA) present at about $1.5 \%$ of total lipids (Sande et al. 2019).

As concerns $R$. cyanoxantha the major fatty acid

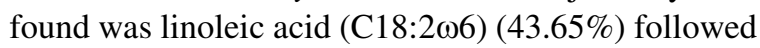
by oleic acid (C18:109) (28.39\%) and palmitic acid (C16:0) (12.95\%) (Grangeia et al. 2011).

The fatty acid composition of different wild Boletus species collected in Portugal was reported by Heleno et al. (2011). (Table 3). The major fatty acid found in 


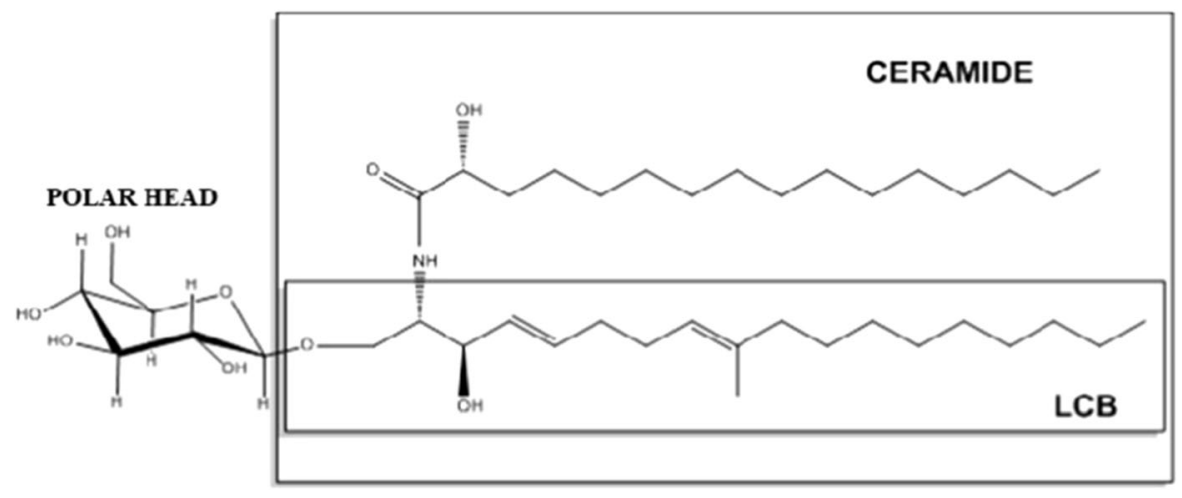

Fig. 2 Chemical structure of mushroom glycosphingolipids

B. edulis was oleic acid (C18:1 $\omega 9)$ (42.5\%) followed

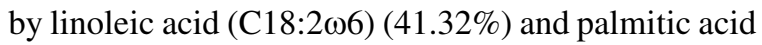
(C16:0) (9.57\%). A very similar profile of fatty acid composition was reported for 33 samples of wild $B$. edulis in the form of caps and stems, collected from selected regions of Poland. The dominant fatty acids in

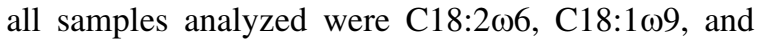
C16:0 (Pietrzak-Fiećko et al. 2016).

Kalogeropoulos et al. (2013) reported the fatty acid composition of wild L. deliciosus from Greece. The prevalent fatty acids were linoleic acid (C18:206) (31.78\%), followed by stearic acid (C18:0) (29.83\%)

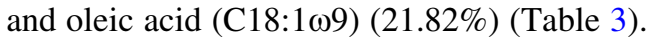

Another class of lipids found in mushrooms is glycosphingolipids (GLSs) and the cerebrosides in particular. A polar head (usually a monosaccharide or a carbohydrate chain) and a fatty acyl group are linked to a long-chain aminoalcohol called a long-chain base (LCB). The fatty acyl chain is amide-linked to the LCB and together they make up the ceramide; the monosaccharide or oligosaccharide group is linked to the primary alcoholic function of the ceramide (Fig. 2).

GLSs are ubiquitous membrane constituents of mushrooms and are believed to possess a wide range of biological activities, including modulation of growth and regulation of differentiation. They are involved in membrane phenomena, such as cell-cell recognition, cell-cell adhesion, antigenic specificity, and other kinds of transmembrane signaling.

$\beta$-Glucosylceramide is by far the most common GLS from mushrooms. A peculiarity of glucosylceramides from mushrooms is the frequent occurrence of a di-unsaturated $\mathrm{C}_{18}$ sphingosine with a methyl branching at C-9. Structure determination was based on carbohydrate analysis, methylation analysis, chemical degradation, and extensive use of FAB-MS (Itonori et al. 2004). Three cerebrosides with different lengths of the fatty acid portion have been isolated and identified from Pleurotus cornucopiae (Paulet) Rolland (Lee et al. 2017). Furthermore, purified acidic glycosphingolipids (AGLs) from $P$. eryngii were reported to induce interleukin-2 (IL-2) release from invariant natural killer $\mathrm{T}$ (iNKT) cells inducing prolonged retention of IL-4 in serum in vitro and in vivo (Fu et al. 2016). So through iNKT cell activation AGLs isolated from $P$. eryngii might be involved in the maintenance of immunohomeostasis.

An important secondary metabolite from mushrooms is lovastatin, a polyketide employed as a cholesterol-lowering drug that inhibits (3S)-hydroxy3-methylglutaryl-coenzyme A (HMG-CoA) reductase. This is a key enzyme in the synthesis of mevalonate, since it is the immediate precursor of cholesterol and lovastatin is the lead compound of all of the drugs classified as statins. Lovastatin was discovered from Aspergillus terreus and Monascus ruber in the 1970s and is a natural product in oyster mushrooms (Chen et al. 2012) (Fig. 3).

Polysaccharides

Mushrooms are a significative source of polysaccharides. The structural complexity of polysaccharides is ascribed to the linkage between two sugar units, through an ether linkage, in several different ways. The reducing end of one sugar $(\mathrm{C} 1)$ can condense with any hydroxyl group of a second sugar (at C2, C3, C4, or C6) so that during polymerization some sugars may be substituted in two positions, leading to branched 


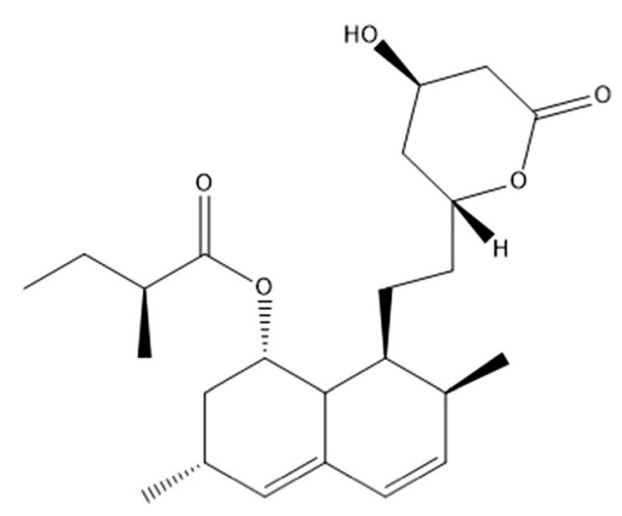

Fig. 3 Chemical structure of lovastatin

chains structures. Besides, the ether linkage can have either a $\alpha$ - or $\beta$-configuration, due to the stereochemistry of simple sugars, and both kinds of linkage can co-exist in some molecule.

Generally, the polysaccharides are present in the mushroom cell wall and include $\alpha$-glucans and $\beta$ glucans. These macromolecules are composed of glucopyranose units linked with glycosidic bonds of the type $(1 \rightarrow 6)-\beta,(1 \rightarrow 3)-\beta$, or $(1 \rightarrow 3)-\alpha$. Mushrooms are characterized by different kinds of polysaccharides that include not only glucans but also heteroglycans and proteoglycan classes. Polysaccharides that include residues of only one type of monosaccharide unit are known as homoglycans, while residues of two or more types of monosaccharide molecules are categorized as heteroglycans (Kozarski et al. 2014).

As concerns, the extraction and purification procedures, usually the polysaccharides are isolated by successive hot-water extractions followed by ethanol precipitation. Chromatographic methods such as sizeexclusion (SEC) and ion-exchange chromatography (IEC) are used as purification procedures of the crude polysaccharides, while chemical reactions of hydrolysis and derivatization together with NMR experiments are useful in providing information for their structural elucidation (Sun et al. 2010a).

Polysaccharides isolated and identified from mushrooms differ in their physical-chemical properties such as in their water solubility, molecular weight, size of the molecule, and structure (Table 4). Recently, polysaccharides isolated from mushrooms have attracted increasing attention for their wide spectrum of biological properties, such as antioxidative, antitumor, immunomodulation (BRMs), and antiinflammatory effects (Selvamani et al. 2018). The major pharmaceutical properties of mushrooms, i.e. antitumor activities and immunity potentiation, are ascribed to $\beta$-glucans. Many fungal $\beta$-glucans stimulate both innate and adaptive immunity. They activate innate immune system components such as natural killer (NK) cells, neutrophils, macrophages, and cytokines. These cytokines, in turn activate adaptive immunity with the stimulation of B-cell for antibodies production and promotion of T-cell differentiation to T-helper cells, which mediate cell and humoral immunities (Oloke and Adebayo 2015).

Pleuran, a water soluble polysaccharide $[\beta-(1,3 /$ 1,6)-D-Glucan], is the best-known $\beta$-glucan isolated from $P$. ostreatus with a molecular weight of $762 \mathrm{KD}$. It is composed of a backbone $(1 \rightarrow 3)$ linked $\beta$-Dglucose with a side chain of a $\beta-(1 \rightarrow 6)$ or $\beta$ $(1 \rightarrow 4)$-D-glucosyl residue of ever fourth glucose unit. The compound exhibit anti-neoplastic properties against different cells, including breast cancer MCF-7, prostate cancer cells PC-3 and colorectal HT-29 cancer cells. It possesses also antiviral and antioxidative properties (Golak-Siwulska et al. 2018).

The purified polysaccharides PEPE-A1 and PEPEA2 from $P$. eryngii are characterized by a $\beta-(1 \rightarrow 3)$ glucan as the backbone accompanied by $\alpha-(1 \rightarrow 6)$-Dglucosyl residues side chains. They showed a strong inhibitory effect on lipid accumulation ( $\mathrm{Fu}$ et al. 2016). Recently, a mannogalactan with the main chain of (1 $\rightarrow 6$ )-linked- $\alpha$-D-galactopyranosyl and 3-Omethyl- $\alpha$-D-galactopyranosyl residues, both partially substituted at $\mathrm{OH}-2$ by $\beta$-D-Manp units was isolated from $P$. eryngii and tested against murine melanoma cells (Biscaia et al. 2017).

Zhang et al. (2014) isolated three subfractions of intracellular zinc polysaccharides (IZPS) from $P$. cornucopiae. All the subfractions have shown antioxidant activities in vitro and in vivo. They were found able to act as upregulatation of the superoxide dismutase, GSH peroxidase and catalase, and significantly decreased the contents of malondialdehyde and lipid peroxidation in vivo. PCPS from $P$. cornucopiae mushroom extract is a $\beta-(1 \rightarrow 6)$-glucan possessing a proinflammatory effect on innate immune cells (Minato et al. 2017).

From A. bisporus a new heteropolysaccharide consisting of ribose, rhamnose, arabinose, xylose, mannose, glucose, and galactose with $1 \rightarrow 2$ and 
Table 4 Polysaccharides of some selected mushrooms species

\begin{tabular}{|c|c|c|}
\hline Mushrooms species & Polysaccharides & References \\
\hline Pleurotus ostreatus & $\begin{array}{l}\text { Pleuran }[\beta-(1,3 / 1,6) \text {-D-Glucan }] \\
\alpha-(1 \rightarrow 3) \text {-glucans } \\
\text { Mycelium polysaccharides } 2 \text { (POMP2), POPS-1 }\end{array}$ & $\begin{array}{l}\text { Selvamani et al. (2018) } \\
\text { Golak-Siwulska et al. (2018) } \\
\text { Sarma et al. (2018) }\end{array}$ \\
\hline Pleurotus eryngii & $\begin{array}{l}\text { PEPE-A1, PEPE-A2 } \\
\text { Partially methylated mannogalactan }\end{array}$ & $\begin{array}{l}\text { Fu et al. (2016) } \\
\text { Biscaia et al. (2017) }\end{array}$ \\
\hline Pleurotus cornucopiae & $\begin{array}{l}\text { Intracellular zinc polysaccharides (IZPS) } \\
\beta \text {-glucan (PCPS) }[\beta-(1 \rightarrow 6) \text {-Glucan] }\end{array}$ & $\begin{array}{l}\text { Zhang et al. (2014) } \\
\text { Minato et al. (2017) }\end{array}$ \\
\hline Agaricus bisporus & $\begin{array}{l}\beta \text {-glucan }[\beta-(1 \rightarrow 6) \text {-Glucan }] \text {, mannogalactan } \\
\text { Heteropolysaccharide ABP Ia }\end{array}$ & $\begin{array}{l}\text { Smiderle et al. (2011) } \\
\text { Liu et al. }(2020 a, b, c)\end{array}$ \\
\hline Cyclocybe aegerita & $\begin{array}{l}\text { Fucogalactan }(\mathrm{FG}-\mathrm{A} a) \\
\text { Ac-MPS, AI-MPS }\end{array}$ & $\begin{array}{l}\text { Motoshima et al. (2018) } \\
\text { Jing et al. (2018) }\end{array}$ \\
\hline Russula cyanoxantha & $\beta$-glucan & Butkhup et al. (2018) \\
\hline Russula virescens & $\begin{array}{l}(1 \rightarrow 3)-\beta \text {-D-glucan, RVP } \\
\text { SRVPs }\end{array}$ & $\begin{array}{l}\text { Sun et al. (2010b) } \\
\text { Li et al. (2020) }\end{array}$ \\
\hline Macrolepiota procera & Polysaccharides & Nowak et al. (2018) \\
\hline Boletus edulis & $\begin{array}{l}\text { Polysaccharides (BEBP-1, BEBP-2 and BEBP-3) } \\
\text { Polysaccharids (BEPF30, BEPF60 and BEPF80) }\end{array}$ & $\begin{array}{l}\text { Luo et al. (2012) } \\
\text { Zhang et al. (2011) }\end{array}$ \\
\hline Lactarius deliciosus & $\begin{array}{l}\text { Polysaccharide (LDG-M) } \\
\text { Polysaccharide (LDG-A) } \\
\text { Polysaccharide (LDG-B) } \\
\text { Polysaccharide (LDGO-A) }\end{array}$ & $\begin{array}{l}\text { Su et al. (2019) } \\
\text { Hou et al. (2019) } \\
\text { Hou et al. (2016) } \\
\text { Ding et al. (2015) }\end{array}$ \\
\hline Coprinus comatus & $\begin{array}{l}\text { Modified polysaccharide (MPCC) } \\
\text { Polysaccharide (CCPP-1) } \\
\text { Polysaccharide (CC30w-1) }\end{array}$ & $\begin{array}{l}\text { Zhao et al. (2019) } \\
\text { Liu et al. (2013) } \\
\text { Zhou et al. (2013) }\end{array}$ \\
\hline Tuber magnatum & $\begin{array}{l}(1 \rightarrow 3)-\beta \text {-D-glucan } \\
(1 \rightarrow 3)-\beta \text {-D-glucan }\end{array}$ & $\begin{array}{l}\text { Tejedor-Calvo et al. (2020) } \\
\text { Tejedor-Calvo et al. (2020) }\end{array}$ \\
\hline $\begin{array}{l}\text { Tuber melanosporum } \\
\text { Tuber borchii }\end{array}$ & $\begin{array}{l}\text { Exo-polysaccharides (TP1, STP1, STP2) } \\
(1 \rightarrow 3) \text { - } \beta \text {-D-glucan }\end{array}$ & $\begin{array}{l}\text { Liu et al. (2020a, b, c) } \\
\text { Tejedor-Calvo et al. (2020) }\end{array}$ \\
\hline
\end{tabular}

$1 \rightarrow 4$ glycosidic bonds and probably $1 \rightarrow 3$ glycosidic bonds was isolated and identified with high in vitro immunobiological activity (Liu et al. 2020a, b, c).

Motoshima et al. (2018) identified a fucogalactan from $C$. aegerita (FG-Aa) characterized by $(1 \rightarrow 6)$ linked $\alpha$-D-galactopyranosyl main chain, substituted at $\mathrm{O}-2$ by non-reducing end units of $\alpha$-L-Fucp, on the average of one to every second residue of the backbone. The obtained fucogalactan was evaluated against arginase from Leishmania amazonensis.

A water-insoluble $(1 \rightarrow 3)$ - $\beta$-D-Glucan was firstly isolated from the fresh fruiting bodies of $R$. virescens, and then the sulfated derivative was synthesized with sulfur trioxide-pyridine complex. The sulfated derivative exhibited enhanced anti-tumor activities against Sarcoma 180 tumor cell (Li et al. 2020). Besides, a water-soluble poaysaccharide (RVP) with anti-oxidant properties was isolated from the fruiting bodies of $R$. virescens consisting of $(1 \rightarrow 6)$-linked- $\alpha$-D-galactopyranosyl and $(1 \rightarrow 2,6)$-linked- $\alpha$-D-galactopyranosyl residues that terminated in a single nonreducing terminal $(1 \rightarrow)$ - $\alpha$-D-mannopyranosyl residue at the O-2 position of each $(1 \rightarrow 2,6)$-linked- $\alpha$-Dgalactopyranosyl residues along the backbone (Sun et al. 2010a). Also RVP was sulfated and in vitro activity test data indicated that the SRVPs showed 
better antioxidant, anticoagulant, antitumor and antibacterial activities compared with RVP.

Three crude polysaccharides (BEPF30, BEPF60, and BEPF80) were isolated from the fruiting bodies of B. edulis and investigated for their antioxidant activities. BEPF60 showed significant reducing power and chelating activity together with the highest inhibitory effects on hydroxyl and superoxide radicals (Zhang et al. 2011). Other crude water-soluble polysaccharides (BEBPs) were extracted from $B$. edulis and evaluated for their antioxidant activities. BEBP-3 showed a significant anti-oxidant activity (Luo et al. 2012).

Lactarius deliciosus is an important source of polysaccharides. Su et al. (2019) reported the structural characterization and immune regulation activity of a novel polysaccharide (LDG-M) from L. deliciosus Gray. LDG-M was composed of $\beta$-D-glucose and $\alpha$-Dlyxose with ratio $2: 1$. The proposed structure of LDG$\mathrm{M}$ was a backbone of 1,6-linked- $\beta$-D-glucose and $1,4,6$-linked- $\beta$-D-glucose, with branches composed of one $(1 \rightarrow 4)$-linked- $\alpha$-D-lyxose residue (Table 4$)$. The structural elucidation of LDG-A indicated a backbone of 1,6-disubstituted- $\alpha$-L-mannopyranose with branches at O-2 mainly composed of a $(2 \rightarrow 3)-\alpha$-Dxylopyranose residue. LDG-A exhibited marked antitumor activities in vivo. A new heteropolysaccharide (LDG-B) with a backbone of $(1,6)$-linked-D-galactose and $(1,2,6)$-linked-D-galactose with branches composed of 4-linked-D-glucose and 6-linked-D-galactose residue was identified from $L$. deliciosus. Cell cycle test data showed that LDG-B could promote the proliferation of $\mathrm{B}$ cells and macrophage cells by affecting G0/G1, S and G2/M phases (Hou et al. 2016). Besides, also the structure elucidation and anti-tumor activity of water-soluble oligosaccharides (LDGO-A) were reported by Ding et al. (2015).

A modified polysaccharide named MPCC was obtained by snailase hydrolysis from $C$. comatus with antioxidant and hepatoprotective properties (Zhao et al. 2019). The structural investigation of CCPP-1 from $C$. comatus has shown that CCPP-1 was $\alpha$-D$(1 \rightarrow 4)$-glucan with branches at C-6 consisting of non-reducing terminal approximately every fourteen residues. While the crude polysaccharide fractions CCPF showed significant hypoglycemic activity, CCPP-1 was not useful on reducing blood sugar (Liu et al. 2013).
As concerns Tuber fruiting bodies and fermentation system, the structure, the physicochemical and biological properties of the polysaccharides have not been thoroughly investigated. Tejedor-Calvo et al. (2020) reported a preliminary screening of the main bioactive compounds for T. magnatum, T. melanosporum and $T$. borchii by using pressurized liquid extractions (PLE). The polysaccharide composition of the obtained extracts was investigated by NMR analysis and their immunomodulatory activity tested in vitro with cell cultures. NMR investigation revealed that the extracted polysaccharides were $\beta-(1 \rightarrow 3)$-glucans and a heteropolymer consisting of galactose and mannose.

Proteins, peptides and lectins

Other macromolecular mycochemicals isolated from mushrooms with high molecular weight are proteins, peptides, and lectins.

The proteins in mushrooms, as in other plants, are high molecular weight polymers of amino acids. The amino acids are arranged in a particular linear order and each protein has a specific amino acid sequence. Proteins are usually purified according to molecular weight so they are subjected to gel filtration on a column of Sephadex. Separation of proteins by gel electrophoresis is also partly determined by their molecular size since their mobility on the gel is closely related to their charge properties (Oloke and Adebayo 2015).

The composition of mushroom proteins seems to be of higher nutritional value concerning most plant proteins. Mushrooms proteins contain all nine essential amino acids required by humans and can be used as a substitute for meat (Kakon et al. 2012). High contents of proteins 38.9 and $36.9 \%$ were observed in A. bisporus and B. edulis, respectively (Nagy et al. 2017). Mushrooms are a rich source of proteins with several properties for biotechnological and medicinal applications. Immunomodulatory proteins (FIPs) are a group of fungal proteins able to alter the cytokine response (Oloke and Adebayo 2015). Proteins isolated from selected mushrooms exhibited antiviral, antitumor, antifungal, and antibacterial properties (Table 5). Moreover, the fruiting bodies and mycelium of several mushrooms are an abundant source of ergothioneine, an unusual sulfur-containing derivative of histidine, with antioxidant properties (Chen et al. 2012). 
Table 5 Proteins, peptides and lectins of some selected mushrooms species

\begin{tabular}{|c|c|c|}
\hline Mushrooms species & Proteins, peptides and lectins & References \\
\hline \multirow[t]{5}{*}{ Pleurotus ostreatus } & $\begin{array}{l}\text { Cibacron blue affinity purified protein } \\
\text { (CBAEP) }\end{array}$ & Sarma et al. (2018) \\
\hline & Pleurostrin & Erjavec et al. (2012) \\
\hline & Dimeric lectin & $\begin{array}{l}\text { Oloke and Adebayo } \\
\text { (2015) }\end{array}$ \\
\hline & Laccase & $\begin{array}{l}\text { Golak-Siwulska et al. } \\
\text { (2018) }\end{array}$ \\
\hline & Concanavalin A & Sarma et al. (2018) \\
\hline \multirow[t]{4}{*}{ Pleurotus eryngii } & Eryngin & Erjavec et al. (2012)@ \\
\hline & Laccase & Fu et al. (2016) \\
\hline & Protease (Pleureryn) & Fu et al. (2016) \\
\hline & PEP 1b & Hu et al. (2018) \\
\hline \multirow[t]{3}{*}{$\begin{array}{l}\text { Pleurotus } \\
\text { cornucopiae }\end{array}$} & Oligopeptides & $\begin{array}{l}\text { Golak-Siwulska et al. } \\
\text { (2018) }\end{array}$ \\
\hline & Laccase & Wu et al. (2014) \\
\hline & Lectin (PCL-M) & Oguri (2020) \\
\hline \multirow[t]{2}{*}{ Agaricus bisporus } & Lectin (ABL) & Verma et al. (2019) \\
\hline & Protein FIIb-1 & Verma et al. (2019) \\
\hline \multirow[t]{3}{*}{ Cyclocybe aegerita } & Ribotoxin-like protein (Ageritin) & Citores et al. (2019) \\
\hline & Lectin (AAL) & Liu et al. (2017) \\
\hline & Lectin (AAL-2) & Ren et al. (2015) \\
\hline \multirow[t]{2}{*}{ Russula virescens } & Laccase & Zhu et al. (2013) \\
\hline & Feruloyl esterase (FAE) & Wang et al. (2014b) \\
\hline $\begin{array}{c}\text { Macrolepiota } \\
\text { procera }\end{array}$ & $\beta$-Trefoil lectin $(\mathrm{MpL})$ & Žurga et al. (2017) \\
\hline Boletus edulis & $\beta$-Trefoil lectin (BeL) & Žurga et al. (2017) \\
\hline Lactarius deliciosus & Laccase & Khaund and Joshi (2014) \\
\hline \multirow[t]{2}{*}{ Coprinus comatus } & Protein Y3 & Nowakowski et al. (2020) \\
\hline & Laccases & Nowakowski et al. (2020) \\
\hline Tuber borchii & Lectin (Cyanovirin-N) & Matei et al. (2011) \\
\hline
\end{tabular}

Many proteins are also enzymes, catalyzing particular steps in either primary or secondary metabolism, and possess health-promoting effects. Laccases were isolated from $P$. ostreatus and $P$. cornucopiae with antiviral effect against the hepatitis $\mathrm{C}$ virus and HIV-1 reverse transcriptase, respectively (Table 5). Lectins are another group of mycochemicals that include polysaccharide-protein and polysaccharide-peptide complexes. Lectins derived from mushrooms exhibit antiproliferative, immunomodulatory, antitumor, HIV-1 reverse transcriptase inhibiting, cell growthregulating, and many more properties (Oloke and Adebayo 2015). Some proteins, peptides, and lectins isolated from various selected mushrooms are reported in Table 5.

From $P$. ostreatus a Cibacron blue affinity-purified protein (CBAEP) was isolated with potent antitumor, anticancer and immunomodulatory activity against Sarcoma-180, Dalton lymphoma (DL)-bearing mice, and B16FO melanoma tumor-bearing mice (Sarma et al. 2018).

Besides, pleurostrin and eryngin are two proteins isolated from $P$. ostreatus and P. eryngii mushrooms with antibacterial and antifungal properties (Erjavec et al. 2012). The laccase isolated from $P$. ostreatus exhibited an antiviral effect against the hepatitis $\mathrm{C}$ 
virus (Golak-Siwulska et al. 2018). A dimeric lectin, composed of subunits with a molecular weight of 40 and $41 \mathrm{KDa}$, isolated from fresh fruiting bodies of $P$. ostreatus exerted antitumor activity in mice bearing sarcoma S-180 and hepatoma H-22 (Table 5).

$\mathrm{Fu}$ et al. (2016) reported the isolation of a laccase from $P$. eryngii with antiviral activity against HIV. The laccase was active against HIV-1 growth with an $\mathrm{IC}_{50}$ of $2.2 \mu \mathrm{M}$ by inhibiting HIV-1 reverse transcriptase. Also a protease named pleureryn, extracted from fresh fruiting bodies of $P$. eryngii, showed $(23.1 \pm 0.6) \%$ and $(91.4 \pm 3.2) \%$ inhibition of HIV-1 reverse transcriptase at 3 and $30 \mathrm{mM}$, respectively (Table 5).

$\mathrm{Hu}$ et al. (2018) reported the functional characterization of a $P$. eryngii protein (PEP $1 b$ ). PEP $1 \mathrm{~b}$ is an immunomodulatory protein with $21.9 \mathrm{KDa}$ able to induce the M1-polarization of the macrophage cell line RAW 264.7 cells through the activation of the TLR4-NF- $\kappa B$ and MAPK signal pathways.

Two types of angiotensin I-converting enzyme (ACE) inhibitory oligopeptides were obtained from the basidioma of $P$. cornucopiae. The amino acid sequences of the two purified oligopeptides were found to be RLPSEFDLSAFLRA and RLSGQTIEVTSEYLFRH. Besides, from the fermentation broth of $P$. cornucopiae was isolated a new laccase with a molecular mass of $67 \mathrm{KDa}$. It inhibited proliferation of the hepatoma cells HepG2, the breast cancer cells MCF-7, and the activity of HIV-I reverse transcriptase with IC50 values of 3.9, 7.6 and, $3.7 \mu \mathrm{M}$, respectively ( $\mathrm{Wu}$ et al. 2014). Besides, a divalent cation-dependent GalNAc-specific lectin (PCL-M) was purified from the mycelia of $P$. cornucopiae. It is a multimeric glycoprotein composed of $40 \mathrm{KDa}$ subunits linked by disulfide bonds (Oguri 2020).

A lectin, isolated from A. bisporus (ABL) showed antiproliferative effects on different cell types and might be useful for glaucoma. Besides, the fruiting bodies of $A$. bisporus are associated with a protein, named FIIb-1, characterized as tyrosinase (Verma et al. 2019).

Recently, a ribotoxin-like protein, named Ageritin was isolated from the basidiomycetes $C$. aegerita. Several biological activities are ascribed to Ageritin such as antibacterial, antiviral, endonuclease, nuclease, antifungal, and cytotoxicity to COLO 320, HeLa and, Raji cells by promoting apoptosis (Citores et al. 2019). The lectin (AAL), isolated from C. aegerita exhibited antitumor activity by inducing apoptosis (Liu et al. 2017), while lectin-2 (AAL-2) and its complexes with GlcNAc and GlcNAc $\beta 1-3$ Gal $\beta 1$ $4 \mathrm{GlcNAc}$ revealed the structural features of specific recognition of non-reducing terminal $\mathrm{N}$-acetylglucosamine (Ren et al. 2015).

A novel laccase was purified and characterized by $R$. virescens. Its $\mathrm{N}$-terminal amino acid sequence was AIGPTAELVV and it was able to degrade various phenolic compounds and to decolorize several dyes (Zhu et al. 2013).

Žurga et al. (2017) isolated novel ricin B-like lectin with a $\beta$-trefoil fold from $M$. procera, designated as $\mathrm{MpL}$ with nematocidal activity indicating a function in protecting fruiting bodies against parasites. MpL was studied for potential delivery of peptidase protein inhibitors to lysosomes showing that it is a promising carrier of protein drugs to intracellular targets.

An antiviral protein Y3 isolated from $C$. comatus showed an inhibitory effect on the tobacco mosaic virus. Y3 has shown anticancer potential inducing caspase-dependent apoptosis in Jurkat cells of human T-cell leukemia. Besides, also laccases from mycelia of C. comatus have shown antiproliferative and antiviral properties (Nowakowski et al. 2020) (Table 5).

\section{Nutritional value of mushrooms}

The consumption of mushrooms as food has ancient origins. There is evidence of their inclusion in the diet, in fact, already in the civilizations of the Greeks and Romans, who considered them "the food of the Gods" (Valverde et al. 2015).

The enormous alimentary potential of mushrooms lies not only in their rich aroma and flavor, which make them an authentic delicacy but also in their high nutritional value so that they are considered functional foods (Barros et al. 2008; Tsai et al. 2009; Wani et al. 2010; Wang et al. 2014c; Kumar 2015; Corrêa et al. 2016; Rathore et al. 2017; Reis et al. 2017; Antunes et al., 2020). The fungal fruiting body is composed mostly of water, so the caloric intake provided by it is very low (about 350-400 kcal kg-1; Kalač 2012). Dry matter (DM) represents only $5-15 \%$, with variable contents of carbohydrates and proteins, but also fibers and minerals, depending on the fungal species (Barros et al. 2008; Wani et al. 2010; Reis et al. 2012; Cheung 
2013; Kalogeropoulos et al. 2013; Wang et al. 2014c; Heleno et al. 2015).

Of all the species of mushrooms cultivated or available in Italy, those belonging to the genus Pleurotus are among the most appreciated for their high nutritional value. Studies have shown that the content of $P$. eryngii carbohydrates, the main components of the fungal fruiting body, is very high $(75.4 \%)$, even comparable to that of wheat grains and oat bran (Venturella et al. 2015; Carrasco-González et al. 2017). C. aegerita has an even higher content, around $84 \%$ (Petrović et al. 2015), in the wild L. deliciosus is $66.61 \mathrm{~g} / 100 \mathrm{~g} \mathrm{dw}$, while that of $C$. comatus, $M$. procera and B. edulis is significantly lower $(58.4 \%$, $54.70 \%$ and $46.95 \%$, respectively) (Tsai et al. 2007; Ayaz et al. 2011; Xu et al. 2019). Lower is also the carbohydrate content of A. bisporus (51.05\%; Atila et al. 2017). Particular is the case of the wild mushrooms $R$. cyanoxantha and $R$. virescens, which, although belonging to the same genus, may show significantly different, and in any case rather low, carbohydrate contents (9.56 and $24.40 \%$, respectively) (Srikram and Supapvanich 2016). Most of the fungal carbohydrates are not digestible and include dietary fiber, cell wall polysaccharides as chitin, ß-glucans and mannans, and oligosaccharides. Mushroom dietary fiber is composed by insoluble fiber: mostly chitin and B-glucans, but also other structural polysaccharides such as hemicelluloses. Soluble fiber (mainly pectines) is generally less than $10 \%$ DM. Pleurotus genus has a high content of crude fiber $(10.2 \%)$, as well as C. comatus (12.5\%), and B-glucans (25.9\%); in particular, the highest amount of B-glucans is found in P. ostreatus (up to 50\%) (Tsai et al. 2007; Corrêa et al. 2016; Carrasco-Gonzalez et al. 2017; Bulam et al. 2019). This makes this genus one of the main and most interesting sources of B-glucans, including pleuran, currently commercialized as a natural immunostimulant (Imunoglukan $\mathrm{P} 4 \mathrm{H} \AA$ ) due to its bioactivity (Carrasco-González et al. 2017; Reis et al. 2017; Golak-Siwulska et al. 2018; Bulam et al. 2019). On the contrary, the chitin level is significantly higher in A. bisporus than in P. ostreatus (Atila et al. 2017). Of the total free sugars, the most abundant is mannitol $(80 \%$ ca, enough to be called "the mushroom sugar"), except in C. aegerita and $C$. comatus, where the dominant sugar is trehalose $(12.49 \mathrm{~g} / 100 \mathrm{~g} \mathrm{dw}$ and $169.14 \mathrm{mg} / \mathrm{g} \mathrm{dw}$, respectively) (Tsai et al. 2007; Wani et al. 2010; Petrović et al. 2015; Atila et al. 2017).

Another important component of the fungal dry matter (19-35\% DM) are proteins, which confer mushrooms a nutritional value comparable to some foods such as meat, eggs and, milk products (Barros et al. 2008; Kalač 2009; Wani et al. 2010; Wang et al. 2014c; Khatun et al. 2015; Corrêa et al. 2016; Rathore et al. 2017). In fact, not only these are highly digestible proteins (e.g. the digestibility of Pleurotus proteins is even higher than plants, that is $90 \%$, hence only slightly below the meat and comparable with casein and eggs), but they also include all the essential amino acids usually found in animal proteins: tryptophan, isoleucine, valine, phenylalanine, leucine, threonine, lysine, histidine, methionine. There are, also, nonessential amino acids such as arginine, glutamic acid, aspartic acid, tyrosine, serine, aspargine, and many others (Tsai et al. 2009; Wani et al. 2010; Çağlarirmak 2011; Erjavec et al. 2012; Kakon et al. 2012; Kalač 2012; Kivrak et al. 2014; Wang et al. 2014c; Kumar 2015; Corrêa et al. 2016; Atila et al. 2017). Excellent protein content was found by Srikram and Supapvanich (2016) in $R$. cyanoxantha $(49.20 \%$, while it was $29.50 \%$ in $R$. virescens), by Ayaz et al. (2011) in B. edulis $(32.50 \mathrm{~g} / 100 \mathrm{~g} \mathrm{dw})$ and a good one by $\mathrm{Xu}$ et al. (2019) in L. deliciosus (17.19 g/100 g dw), rather low $(4.22 \%)$, instead, in $M$. procera. Recent studies have shown as P. ostreatus (protein content 23\%) meets the nutritional requirements for all essential amino acids, or even doubles or triples for some of them (Corrêa et al. 2016; Carrasco-González et al. 2017; Bulam et al. 2019), and that A. bisporus has significant amounts of numerous essential and nonessential amino acids, with an overall protein content of $29.14 \%$ (Kakon et al. 2012; Atila et al. 2017). Also relevant is the fact that mushrooms are the major food source of ergothioneine, especially B. edulis, and some species also of glutathione (mainly $C$. aegerita among the national mushrooms, followed by B. edulis and $P$. ostreatus), amino acid compounds that are important antioxidants (Kalaras et al. 2017). Interesting is also the content of $\gamma$-aminobutyric acid (GABA), a hypotensive agent, in $C$. comatus, as well as in B. edulis (Tsai et al. 2007). Therefore, mushrooms are a viable dietary alternative for vegetarians and vegans and also an ideal component of healthy food especially for child development. 
One more advantage of mushrooms as nutrients is their low crude fat content (2-6\% of DM), making them suitable for a low-calorie diet. Among the species of the genus Pleurotus, the lowest lipid levels are found in P. nebrodensis (Inzenga) Quél. (1.6\%), while the highest in P. eryngii and P. ostreatus $(3.5 \%$ and 3.4\%, respectively) (Venturella et al. 2015; Carrasco-González et al. 2017; Sande et al. 2019). The crude fat content of $C$. comatus is $3.11 \%$ (Tsai et al. 2007), while lower are that of B. edulis and $M$. procera ( $2.85 \%$ and $2.40 \%$, respectively) (Ayaz et al. 2011), whereas L. deliciosus show a slightly higher content (4.82 g /100 g dw) (Xu et al. 2019). A higher fat content was found in $R$. virescens $(12.54 \%)$ and $R$. cyanoxantha (7.87\%) (Srikram and Supapvanich 2016). Generally, in mushrooms, the unsaturated fatty acid prevail over the saturated ones. In Pleurotus spp., for example, monounsaturated fatty acids prevails over others, accounting for up to about $70 \%$ of the total, and their content is considerably higher than other species such as A. bisporus (Corrêa et al. 2016). In this species, the essential polyunsaturated linoleic acid is the most abundant, 5-folds more than in P. ostreatus, followed by palmitic, stearic, oleic acids, and others (Atila et al. 2017; Sande et al. 2019). As reported by Reis et al. (2012), however, the total content of monounsaturated fatty acids is higher in P. eryngii and P. ostreatus; in the latter, the oleic acid seems to be the prevailing monounsaturated fatty acid while linoleic acid is the major polyunsaturated one, whereas palmitic acid is the most abundant among the saturated ones (Corrêa et al. 2016). Also in C. aegerita linoleic acid is the most abundant (78.4\%), followed by palmitic, oleic and, stearic acids (Petrović et al. 2015). In L. deliciosus, on the other hand, the prevalent fatty acid is palmitic, followed by stearic, oleic, and linoleic acid (Xu et al. 2019). Thus, mushrooms can play an important role in nutrition as a source of essential fatty acids for humans as linoleic and linolenic.

The content of primary vitamins such as riboflavin, niacin, thiamine, tocopherol, vitamin of D complex, and folates is noteworthy (La Guardia et al. 2005). Mushroom is, thus, the only non-animal-based food containing vitamin D. As regards niacin, a significantly high content $(5.9 \mathrm{mg} / \mathrm{kg})$ was found in P. eryngii var. eryngii (DC.) Quél., hence sufficient to satisfy $55-82 \%$ of the recommended dietary allowance (RDA) of nicotinic acid, and higher than that of other mushroom species such as $P$. ostreatus $(4.95 \mathrm{mg})$, A. bisporus $(3.8 \mathrm{mg})$ and Boletus spp. $(0.8 \mathrm{mg})$; the riboflavin content $(0.2 \mathrm{mg} / \mathrm{kg})$ is similar for all these species, while the values of biotin are higher for P. eryngii $(7.45 \mu \mathrm{g})$ (Venturella et al. 2015; Atila et al. 2017). A high vitamin B12 and riboflavin content has been reported for P. nebrodensis (La Guardia et al. 2005; Venturella et al. 2015). B. edulis is the mushroom species with significant ascorbic acid content $(4.11 \mathrm{~g} / \mathrm{kg} \mathrm{dw})$ as found by Ayaz et al. (2011). If compared with vegetables, mushrooms have riboflavin content significantly higher. The bioavailability of folates is good, content in ergosterol (a precursor of vitamin D2) is high. For this reason, mushrooms are particularly suitable for those who need to take ergocalciferol from foods of non-animal origin, such as vegetarians and vegans. Also of note is the vitamin $\mathrm{C}$ content in Pleurotus spp. (Kalač 2009, 2012; Çağlarirmak 2011; Feeney et al. 2014; Kumar 2015; Atila et al. 2017; Rathore et al. 2017; Papoutsis et al. 2020). Compared with vegetables, mushrooms have a higher or similar content of microand macro-elements, mostly $\mathrm{K}$ and $\mathrm{P}$, followed by $\mathrm{Ca}$, $\mathrm{Mg}$, and Fe (La Guardia et al. 2005; Wani et al. 2010; Ayaz et al. 2011; Kakon et al. 2012; Kalač 2012; Wang et al. 2014c; Corrêa et al. 2016; Atila et al. 2017; Carrasco-González et al. 2017). Particularly interesting is the iron content of $P$. ostreatus, which overcomes that of pork and beef liver (23.3 and $4.9 \mathrm{mg} \mathrm{Fe} / 100 \mathrm{~g}$ ) (Carrasco-González et al. 2017). Thanks to the lower $\mathrm{Na}$ content that characterizes them, mushrooms are recommended for the prevention of hypertension and particularly for the diet of whose suffer from this medical condition (Vetter 2003; Kalač 2012; Rathore et al. 2017).

No less important is the characteristic and excellent aroma of edible mushrooms, which, together with the texture of their flesh, makes them a valid and delicious substitute for meat and an ideal enrichment for many dishes. Mushrooms are appreciated for their umami or savory flavor, deriving from non-volatile (taste) and volatile (smell) components, such as terpenes, aldehydes, lactones, free amino acids, aromatic alcohols, $5^{\prime}$-nucleotides, soluble sugars, ketones, octanes, and octenes (Kalač 2009, 2012; Tsai et al. 2009; Feeney et al. 2014; Wang et al. 2014c; Atila et al. 2017; Rathore et al. 2017).

Also in Tuber species, there is interesting nutrient composition, which changes qualitatively and 
quantitatively at various stages of maturation. Basically, their composition reflects that of the most commonly described fungi, with the exception of two characteristics: the absence of mannitol and the presence of melanins. As reported by Harki et al. (2005) and Lee et al. (2020), T. melanosporum and T. magnatum, two common species in Italy and among the most appreciated among truffles, are rich in proteins, $\mathrm{K}$ and $\mathrm{P}$, sulfur amino acids and unsaturated fatty acids such as oleic and linoleic acid (more than $60 \%$ of total FA content). More specifically, the mature (stage VI) ascocarps of $T$. melanosporum contain $30.6 \%$ carbohydrates (lower than many species of basidiomycetes), $29.7 \%$ proteins, and $5.4 \%$ lipids, of which linoleic acid prevails (55.9\%), followed by oleic and palmitic acid.

According to Patel et al. (2017) and Wang and Marcone (2011), truffles are reached in free (particularly the sulfur-containing cysteine and methionine) and essential amino acids (methionine, phenylalanine, valine, serine, isoleucine, and threonine), metals (Fe, $\mathrm{Ca}, \mathrm{K}, \mathrm{P}, \mathrm{Cu}, \mathrm{Zn}$, and $\mathrm{Mn}$ ), contain rhamnose, ergosterol (especially in T. melanosporum, $1.90 \mathrm{mg} /$ $\mathrm{g} \mathrm{DM}$ ), as well as being rich in melanins (up to $15 \%$ dry weight). Also important are their volatile organic compounds such as aldehydes, alcohols, ketones, and organic acids (ascorbic acid), responsible for their typical umami and aroma.

\section{Chemical composition of Italian wild mushrooms}

The consumption pattern from Europe shows a greater preference for wild mushrooms than for cultivated ones (Peintner et al. 2013). In Italy, gathering wild mushrooms is a common practice due to the favorable geographic conditions where the Alps, the Apennine mountains and the forests of southern Italy are ideal grounds for the growth of the most popular mushrooms. The knowledge of edible species is necessary since non-edible ones may have toxic effects. The peak season for mushroom gathering in most areas of Italy is from April to early November, with variations from region to region. Weather conditions are key factors for an abundant mushroom season, which requires a perfect combination of sun, rain, humidity, and warmth.

With the aim of evaluating the chemical composition of mushrooms widely consumed in Italy, different species have been examined to determine their proximate composition.

Pseudomonas eryngii var. eryngii the 'cardoncello' mushroom, is a highly prized and widely distributed edible mushroom throughout Italy. Protein acidic extracts of Mediterranean culinary-medicinal Oyster mushrooms $P$. eryngii var. eryngii, $P$. eryngii var. ferulae (Lanzi) Sacc., P. eryngii var. elaeoselini Venturella, Zervakis \& La Rocca and P. nebrodensis were tested for their in vitro growth inhibitory activity against Staphylococcus aureus ATCC 25,923, Staphylococcus epidermidis RP 62A, Pseudomonas aeruginosa ATCC 15,442 and Escherichia coli ATCC 10,536. All the Pleurotus species analyzed inhibited the tested microorganisms in varying degrees (Schillaci et al. 2013).

From the basidiomata of the edible mushroom $P$. eryngii var. elaeoselini three water-soluble glucans (PELPS-A1, PELPS-A2 and PELPS-A3) were obtained from the hot water extract by chromatography on DEAE-cellulose 32 and Sephadex G-100 column. Acid hydrolysis, periodate oxidation and NMR experiments $\left({ }^{1} \mathrm{H}-,{ }^{13} \mathrm{C}-\mathrm{NMR}\right.$, DQF-COSY, TOCSY, ROESY, HMQC and HMBC) were useful in providing information for their structural elucidation. Based on the data obtained, the structures of the repeating unit of the three isolated polysaccharides were established as follows: 
(1) PELPS-A1:

$\left\{[\rightarrow 3)-\alpha-D-G l c p-(1 \rightarrow]_{3} \rightarrow 4\right)-\alpha-D-G l c p-(1 \rightarrow 2)-\alpha-D-G l c p-(1 \rightarrow 6)-\alpha-D-G l c p-\left(1[\rightarrow 6)-\beta-D-G l c p-(1 \rightarrow]_{2}\right\}_{\text {n }}$
$\quad 6$
$\uparrow$
$\quad 1$
$\alpha$-D-Glcp

(2) PELPS-A2: $[\rightarrow 6)-\beta-D-G l c p-(1 \rightarrow 6)-\beta-D-G l c p-(1 \rightarrow 6)-\beta-D-G l c p-(1 \rightarrow]_{n}$

3

$\uparrow$

1

$\beta$-D-Glcp

(3) PELPS-A3: $[\rightarrow 6)-\alpha-D-G l c p-(1 \rightarrow 6)-\alpha-D-G l c p-(1 \rightarrow 6)-\alpha-D-G l c p-(1 \rightarrow]_{n}$

PELPS-A1 is a new polysaccharide, isolated and identified for the first time from $P$. eryngii var. elaeoselini. The crude extract of $P$. eryngii var. elaeoselini was tested for the antioxidant activity by DPPH and hydroxyl radical scavenging assays showing an $\mathrm{SC}_{50}$ of $1.4 \mathrm{mg} / \mathrm{mL}$ and $\mathrm{SC}_{50}$ of $5.7 \mathrm{mg} / \mathrm{mL}$, respectively. In vitro, antioxidant tests showed that the three isolated polysaccharides exhibited moderate and similar hydroxyl radical scavenging activity (Cateni et al. 2020).

Costa et al. (2015) developed a headspace-solidphase microextraction (HS-SPME) method coupled with GC-MS and GC-FID to evaluate the volatile profiles of ten wild mushroom species including $C$. aegerita and L. deliciosus collected in south Italy. The mushroom $C$. aegerita showed consistent amounts of ethanol (34\%), isopropyl acetate (10\%) and isopentanol (30\%), while L. deliciosus presented not only an abundant fraction of 3-octanone but also consistent amounts of terpenoids, such as limonene (5\%), linalool (8\%), and dihydrocitronellol (4\%).

C. aegerita, commonly known as Pioppino, an edible wild species of the Campania Region (southern Italy), was screened for its bio-chemical composition, nutritional values, and antioxidant effect. GC-MS analysis showed that the most abundant unsaturated acid in Pioppino was linoleic acid (C18:2; $0.618 \mathrm{~g} \mathrm{~kg}^{-1}$ ), while palmitic acid (C16:0; $0.107 \mathrm{~g} \mathrm{~kg}^{-1}$ ) was the major of saturated fatty acids.

The alcoholic extracts of three different samples of Pioppino were analyzed by liquid chromatographyhigh resolution mass spectrometry (LC-HRMS) in full scan mode (Landi et al. 2017a). Pioppino was mainly constituted of disaccharides, hexitol derivatives and malic acid. Other metabolites as saccharopine, agaritine, pentosylhexitol, ergothioneine, $\gamma$-glutaminyl-4-hydroxybenzene, pentosyl xanthosine, homogentisic acid, malic acid, pentos-2-ulose, fumaric acid, veratric acid, $p$-cumaric acid, $o$-cumaric acid, $\delta$-tocopherol and, $\gamma$-tocopherol were identified by comparison of their relative retention times and MS/ MS spectra with those of reference pure compounds.

Wild mushrooms [Fistulina hepatica (Schaeff.) With., Infundibulicybe geotropa (Bull.) Harmaja, Laetiporus sulphureus (Bull.) Murrill, Macrolepiota procera var. procera (Scop.) Singer and Suillus granulatus (L.) Roussel] collected in different forests of Sicily (southern Italy) were analyzed for the content of protein, fat, carbohydrate and, vitamins showing their importance from a nutritional point of view (Palazzolo et al. 2012).

A lectin was isolated from the wild mushroom $B$. edulis (porcini mushroom) collected in Italy. This protein is a dimer and each monomer folds as a $\beta$ trefoil domain. Its X-ray structure, the interaction with galactose, lactose, N-acetylgalactosamine, Gal $\beta 1$ 3GalNAc and, T-antigen disaccharide were studied together with its antiproliferative properties on human cancer cells (Bovi et al. 2013).

B. edulis is a culinary mushroom highly appreciated for its aroma, but fresh mushrooms are very perishable products with a limited shelf life of 1 to 3 days at room temperature. Thus, dehydration is one of the significant preservation methods used for the storage of mushrooms. The composition of volatile compounds of dried porcini mushroom during commercial shelflife (up to 12 months) at the storage temperature of $20{ }^{\circ} \mathrm{C}$ and under stressed conditions at $37^{\circ} \mathrm{C}$ was investigated using two mass spectrometry (MS)-based techniques. 
66 volatile compounds were identified, 36 of which reported for the first time. Alcohols, aldehydes, ketones, and monoterpenes diminish during the storage while carboxylic acids, pyrazines, lactones and, amine increase. The storage temperature influences the final quality of the dried porcini (Aprea et al. 2015).

The mycochemical studies regarding truffles are mainly focused on the complex mixture of volatile organic compounds (VOCs) released from their ascomata that in addition to their biological value determine their economic value.

T. magnatum grows in some regions in Italy (Tuscany, Piedmont, Marche and, Umbria) and its volatile organic compounds were analyzed by PTRTOF-MS experiments comparing samples from different regions of Italy and different seasons (Vita et al. 2015). The chemical composition of the aroma has led to the identification of 111 compounds divided into six different chemical classes as follows: hydrocarbons, aromatic hydrocarbons, phenols, sulfur compounds, terpenes, and other compounds. The VOCs profiles vary within the different seasonal and geographical productions.

A further study of the VOCs generated by $T$. magnatum fruiting bodies from different regions of Italy with different environmental conditions was reported by Vita et al. (2018). The white truffle's aroma is frequently correlated to sulfur-containing volatiles which can be used to trace the origin of truffle fruiting bodies. Dimethyl sulfide, dimethyl disulfide, bis (methylthio) methane were detected in all samples, dimethyl trisulfide in some samples while S-allylthiopropionate and 3-methylthio-propionaldehyde were found for the first time in the aroma. Aldehydes [e.g. (4Z)-decenal, (2E)-butenal, 4-methylpent-2-enal, 2-methylpent-2-enal], alcohols [e.g. 1-octen-3-ol, dodecanol, (4Z)-decen-1-ol], ketones [e.g. 3-octanone, 2-octanone, 6-methyl-5-hepten-2-one, 2-decanone, 2-undecanone], terpenes [e.g. limonene, $\alpha$ - and $\beta$ pinene, $\alpha$-terpinene, eucalyptol, camphor], hydrocarbons and esters [e.g. (2E)-hexenyl-acetate, ethyl lactate, 3,5,5-trimethylhexyl-acetate, isobutyl pentanoate, 3-acetoxyoctane] were also detected.

Besides, since the quality of the fruiting bodies of $T$. magnatum varies significantly based on of the origin area due to the differences in environmental growth conditions, a proteomic analysis was reported for samples collected in different areas of Italy (Vita et al. 2017).

As concerns the black truffle T. melanosporum Vitt. the volatile organic compounds from samples collected in middle Italy and the variation induced by the storage temperature was reported (Bellesia et al. 1988). The major volatile compounds of $T$. melanosporum are butan-2,3-dione, 2- and 3-methylbutanal, 2- and 3-methylbutanol. The two aldehydes (2- and 3-methylbutanal) and two alcohols (2- and 3-methylbutanol) play an important role, while sulfur compounds are present at trace levels. On storage, all these compounds are lost, but at $0{ }^{\circ} \mathrm{C}$, an increase of the 2- and 3-methyl butanal and of 2- and 3-methyl butanol occurs.

In many cases, T. borchii is illegally used as a substitute of the more appreciated T. magnatum. The composition of the volatile organic fraction of $T$. borchii was analyzed by gas-solid extraction and purge and trap injection in GC-MS, together with the variations during storage (Bellesia et al. 2001). In fresh samples the aroma mainly consists of a mixture of alcohols, the most important one is 1-octen-3-ol together with aldehydes and 2- and 3-methylthiophenes as sulfur compounds. Also for T. borchii the best preservation conditions seem to be at $0{ }^{\circ} \mathrm{C}$, while comparing $T$. borchii with $T$. magnatum, the absence in the volatile fraction of dimethyldisulfide, dimethyltrisulfide and 2,4-dithiapentane seems to be the distinguishing feature.

D'Auria et al. (2012) reported a further study on volatile organic compounds of samples of $T$. borchii and T. asa-foetida Lesp., collected in woodlands of the Basilicata region (southern Italy). Solid-phase microextraction-gas chromatography-mass spectrometry analysis of the samples showed the presence of 2-methyl-1,3-butadiene as the significant component in both truffles. In $T$. borchii 3-methylbutanal, 3-methyl-1-butanol and tetradecane were present in low amounts.

Besides, a lectin named TBFL-1 was isolated and identified from $T$. borchii. The fruiting body that is able selectively to bind the exopolysaccharides produced by ascoma-associated Rhizobium spp. TBFL-1 is a $11.9-\mathrm{KDa}$ phase-specific protein, it is a nonglycosylated polypeptide chain localized on the hyphal cell wall and is the main soluble protein in the fruiting body aqueous extract. Studies of the related gene $t b f-1$ 
demonstrated the presence of an N-terminal signal peptide of 12 amino acids (Cerigini et al. 2008).

\section{Chemical composition of Italian cultivated mushrooms}

A study conducted on different mushroom strains cultivated in an Italian farm (Italmiko, Senise-Potenza, Italy) was carried out by solid-state 13C CPMAS NMR (Pizzoferrato et al. 2000). This technique can investigate the chemical composition in the solid-state of a food sample. This property was useful to study mushrooms of different species $[P$. ostreatus, $P$. eryngii, Pleurotus pulmonarius (Fr.) Quél. And $L$. edodes] to obtain the quantitative evaluation of the protein/polysaccharide ratio. The value of the protein/ polysaccharide ratio has been correlated with the results obtained by chemical analysis and a good correlation $(\mathrm{R} 2=0.93 ; \mathrm{R} 2=0.81)$ has been obtained. As concerns $P$. ostreatus the resonances are quite similar and only slight changes in the relative intensity can be observed. The $P$. eryngii samples analyzed show a similar pattern with a high content of polysaccharides and a low amount of proteins.

$P$. ostreatus, $P$. eryngii and $C$. aegerita were investigated for their $\beta$-1-3-glucan synthase activity and its induction by olive mill wastewaters (OMW) (Reverberi et al. 2004). In the control medium, although with different degrees, all fungal strains displayed $\beta-1,3$-glucan synthase activity. When the isolates grew on OMW an increase of about 12-fold was observed for $P$. ostreatus, while no differences were reported for $P$. eryngii and C. aegerita.

Two different polysaccharides (PEPS-A1 and PEPS-A2) were isolated from the cultivated edible mushroom, P. eryngii C-142-c strain. The chemical structures of the repeating unit of PEPS-A1 and PEPSA2 were established based on acid hydrolysis, methylation analysis, and NMR experiments as follows:

(1) PEPS-A1 ( $\alpha$-glucan):

$$
\begin{aligned}
& {[\rightarrow 6)-\alpha-\mathrm{D}-\text { Glcp }-(1 \rightarrow 6)-\alpha-\mathrm{D}} \\
& \quad-\text { Glcp }-(1 \rightarrow 6)-\alpha-\mathrm{D}-\mathrm{Glcp} \\
& \quad-(1 \rightarrow]_{\mathrm{n}}
\end{aligned}
$$

(2) PEPS-A2 ( $\beta$-glucan):

$$
\begin{aligned}
& {[\rightarrow 6)-\beta-\mathrm{D}-\text { Glcp }-(1 \rightarrow 6)-\beta-\mathrm{D}} \\
& \quad-\text { Glcp }-(1 \rightarrow 6)-\beta-\mathrm{D}-\text { Glcp } \\
& \quad-(1 \rightarrow]_{\mathrm{n}}
\end{aligned}
$$

The antioxidant activity of PEPS-A1 and PEPS-A2 was evaluated by hydroxyl radical scavenging activity test showing $\mathrm{SC}_{50}$ values of $400 \mu \mathrm{g} / \mathrm{mL}$ and $122 \mu \mathrm{g} /$ $\mathrm{mL}$, respectively. Both polysaccharides affected cell viability after 48 and $72 \mathrm{~h}$ of treatment, inducing the death of $50 \%$ of HT-29 cells between 0.25 and $1 \mu \mathrm{g} /$ $\mathrm{mL}$ and 0.5 and $1 \mu \mathrm{g} / \mathrm{mL}$, respectively for PEPS-A 1 and PEPS-A2 (Cateni et al. 2018).

Punelli et al. (2009) reported the molecular characterization and enzymatic activity of laccases in $P$. eryngii and P. eryngii var. ferulae. Using a PCRbased approach, four putative laccase genes (lacl, lac2, lac 3 and lac5-like gene) have been isolated and identified in both $P$. eryngii and $P$. eryngii var.ferulae.

Multiple headspace-solid phase microextraction (MHS-SPME) followed by gas chromatography/ mass spectrometry (GC-MS) and flame ionization detection (GC-FID) was applied to the identification and quantification of volatiles from the mushroom $A$. bisporus (Costa et al. 2013). 1-Octen-3-ol, 3-octanone, 3-octanol, 1-octen-3-one and benzaldehyde are key compounds of mushroom samples analyzed. Quantitative differences among the samples were observed, in particular for 1-octen-3-ol when fresh mushrooms were differently pre-treated $\left(0.75\right.$ and $3.30 \mu \mathrm{g}^{-1}$, in chopped and homogenized samples, respectively). It seems that from 1-octen-3-ol breakdown other 8-carbon compounds are formed: 3-octanone (3.34 vs. $\left.2.01 \mu \mathrm{g}^{-1}\right)$ and 3 -octanol $\left(0.19\right.$ vs. $\left.0.07 \mu \mathrm{g}^{-1}\right)$ were found in high amount in chopped samples, balancing the reduced presence of 1-octen-3-ol.

Agaricus bisporus is the most cultivated mushroom in Italy. Samples of the cultivated species A. bisporus in Sicily (South Italy) were analyzed by the headspace-solid-phase microextraction (HS-SPME) method coupled with GC-MS and GC-FID to evaluate compositional changes occurring during storage (Costa et al. 2015). 51 compounds were identified, with high amounts of C8 compounds such as 3-octanone, 3-octanol and (2E)-octenol. Besides, compounds with the aromatic ring were determined at significative amounts, such as benzaldehyde and benzyl alcohol. In Italy, A. bisporus, when purchased 
in the supermarkets, is found in refrigerated counters. So, 10-day-old mushrooms, kept in the refrigerator were analyzed. After 10 days of storage, a reduction of about $3.5 \%$ of the volatile fraction was observed. Ethanol, (2E)-octenol and phenylacetaldehyde were not detected in the stored mushrooms. As concerns compounds with aromatic ring a drastic decrease was observed. The amount of terpenoids was constant, while a reduction of $\mathrm{C} 8$ compounds, 3-octanol and (2E)-octenol was observed.

Landi et al. (2017a) reported the nutritional value, chemical composition, and anti-radical properties of cultivated A. bisporus (J.E. Lange) Imbach purchased in Campania (South Italy). As concerns fatty acid composition analysis the most abundant unsaturated acids in Champignon were linoleic (C18:2; $\left.0.858 \mathrm{~g} \mathrm{~kg}^{-1}\right) \quad$ and $\gamma$-linolenic $(\mathrm{C} 18: 3$; $0.243 \mathrm{~g} \mathrm{~kg}^{-1}$ ), which represented $67 \%$ and $19 \%$ of the total, respectively. The prevalence of polyunsaturated fatty acids (PUFA) showed linoleic acid (C18:2) as the major fatty acid, while palmitic acid (C16:0) was the major of saturated fatty acids (SFA). The tentative identification of constituents from Champignon alcoholic extract by liquid chromatography-high-resolution mass spectrometry (LCHRMS) showed the presence of mannitol, saccharopine, trehalose, agaritine, pentosylhexitol, ergothioneine, $\gamma$-glutaminyl-4-hydroxybenzene, malic acid, fumaric acid, ferulic acid, sinapic acid, and cinnamic acid.

\section{Mycochemicals as nutraceuticals}

Mushrooms are an excellent food not only from a culinary point of view, as unique sensory experiences, but also for well-being because of the many positive effects they have on the human body, helping it to maintain a good state of health and defend it against illness. This aspect is becoming increasingly important in a society more and more threatened by an unhealthy lifestyle, pollution, radiation and many other stress factors. Thereby in the last decades, the gaze on food has changed, and new concepts of it were developed. The term 'nutraceuticals' was first used by de Felice (1989) who, combining the words nutrition and pharmaceuticals, defined them as 'a food (or part of a food) that provides medical or health benefits, including the prevention and treatment of a disease'.
The term "mushroom nutraceuticals" refers to refined or partially refined extracts, single compounds or nutrients, or dried biomass obtained from either mushroom mycelium or fruiting body, usually included in dosed, concentrated, and purified form in different pharmaceutical formulations such as capsules, tablets, pills, etc., and consumed as a dietary supplement and has potential therapeutic applications (Reis et al. 2017). Nonetheless, being considered nonspecific biologic therapies, nutraceuticals differ from pharmaceuticals in that they are not currently subject to medical prescription and their therapeutic properties are not recognised from a legal point of view. Since 2011, in fact, in EU the registration and marketing of 'botanical medicinal products' is no longer permitted and, therefore, despite their pharmacological properties, they can only be classified as food supplements, falling under EU Regulation no. 1924/2006 (Pirillo and Capatano 2014). Therefore, several aspects of their preparation and marketing remain still unresolved, such as standardization of the production chain, safety parameters, regulation, efficacy, and mechanism of action. Although the market does not have production standards, it is mainly developed in Asian countries; Western countries, on the other hand, are used to buy from the East finished products for resale or raw materials (powders and extracts not always of ascertained origin) and then make the final pipeline. In these areas, therefore, the potential for exploitation and investment is enormous.

Several recent studies have demonstrated the multiple nutraceutical properties of mushrooms by the presence of numerous bioactive molecules that give them antioxidant, antimicrobial, antitumor, immunomodulating, anti-hypercholesterolemia, antiinflammatory, antiviral, radical scavenging, hypolipidemic, antithrombotic, hepatoprotective, anti-hypercholesterolemia, hypotensive, and anti-diabetic activities, antinociceptive and cardiovascular beneficial effects (Barros et al. 2008; Carrasco-González et al. 2017; Gargano et al. 2017; Rathore et al. 2017; Reis et al. 2017; Ma et al. 2018; Islam et al. 2019). These bioactive compounds, contained in different quantities depending on the fungal species and growing conditions, are the most varied, including polysaccharides and especially ß-glucans, dietary fibers, phenolics, peptides, terpenes, glycoproteins, ergosterols, alcohols, unsaturated fatty acids (UFA), lectins, tocopherols, ascorbic acid, carotenoids and others 
(Barros et al. 2008; Rathore et al. 2017; Reis et al. 2017; Ma et al. 2018; Islam et al. 2019).

As for the genus Pleurotus, many species belonging to it have shown activity against various chronic diseases in various studies, thus with a wide spectrum for potential biotechnological applications. They possess numerous bioactive compounds such as polysaccharides, lipopolysaccharides, proteins, peptides, glycoproteins, nucleosides, triterpenoids, lectins, lipids, and their derivatives (Patel et al. 2012; Talkad et al. 2015; Golak-Siwulska et al. 2018). Fruiting bodies possess higher concentration of antioxidants than other commercial mushrooms (Talkad et al. 2015); the AOX properties of different kinds of Pleurotus extracts efficiently contrast reducing the occurrence of age-associated disorders like stroke, Parkinson's disease, atherosclerosis, diabetes, cancer, and cirrhosis (Patel et al. 2012); they help also to reduce the severity of inflammatory skin disease and regulate hyperpigmentation disorders (Taofiq et al. 2016).

Pleuran is the polysaccharide isolated from Pleurotus spp. A variety of properties such as immunomodulatory, antitumor, AOX, antiviral and antimicrobial, and anti-inflammatory. It was also found that by including $100 \mathrm{mg}$ of Imunoglukan in the diet of elite athletes, the suppressed immune system responses induced by short-term high-intensity exercise decreased (Bobovčák et al. 2010).

Studies have remarked also on the importance of proteins isolated from $P$. ostreatus and $P$. eryngii (pleurostrin and eryngin) as an effective antifungal and antibacterial agents (Carrasco-González et al. 2017). Many bioactive compounds of Pleurotus spp. and their properties are reported in Table 6.

A. bisporus is also of increasing importance thanks to the innumerable medicinal properties of its bioactive extracts and compounds, which make it suitable against many human diseases such as coronary heart diseases, diabetes mellitus, bacterial and fungal infections, disorders of the human immune system, and cancers (Öztürk et al. 2011; Atila et al. 2017). Even the Canadian Cancer Society recommends its consumption because of its beneficial effects against various diseases (Atila et al. 2017). The high dietary fiber and antioxidant content of this mushroom, including vitamins C, D, and B12, as well as folate and polyphenols have positive effects on diabetes and cardiovascular diseases (Atila et al. 2017).
Moreover, the prebiotics contained in the fruiting bodies has a positive influence on gut health. A study conducted by Hess et al. (2018) has shown that, compared to meat, the consumption of mushroom may impact laxation in healthy adults. It is demonstrated by the increase in stool weight and presence of undigested mushrooms in stool and by the different fecal microbiota composition, with a greater abundance of Bacteroidetes and lower presence of Firmicutes.

In vivo tests on mice have shown analgesic and antipyretic properties comparable to that of the common drug diclofenac (Bose et al. 2019). As reported by Ismaya et al. (2020), recently a new molecule from A. bisporus has been discovered; is a mannose-binding protein (Abmb) that might be employed as a drug carrier for oral administration due to its capability to permeate a dialysis bag made of fresh jejunum ex vivo, that doesn't suffer alterations in a bioconjugation with a drug model, and to its resistance to the harsh gastrointestinal tract (Ismaya et al. 2020). Some activities and compounds of A. bisporus are reported in Table 7.

Other mushrooms already mentioned, which can be found spontaneous or cultivated in Italy, are still less studied compared to the previous ones. This is also due to the fact that their consumption is often smaller in quantitative terms or less widespread. Some of the studies carried out to date are reported in Table 7. They reveal the enormous therapeutic potential of these mushrooms, as well as the benefits that their more frequent inclusion in the diet would bring to the individual's state of health.

As far as truffles are concerned, most of the studies carried out refer to the culinary aspect, analyzing their composition and focusing mainly on the volatile components responsible for their particular aroma and flavor.

In recent years, studies on the therapeutic potential of this type of food are increasing.

It has been seen, in fact, as Tuber spp. have numerous bioactive compounds, with properties ranging from anti-tumor to anti-inflammatory, antioxidant, hepatoprotective, anti-cholesterolemic, and even antidepressant. In Table 7 some bioactivities of this genus are reported.

A more recent topic concerns the nutraceutical benefits of UV irradiation of cultivated A. bisporus and $P$. ostreatus to generate high amounts of vitamin D2 and to maintain the ability of the fungus to inhibit 
Table 6 Bioactivities of Pleurotus spp

\begin{tabular}{|c|c|c|c|c|}
\hline Activity & $\begin{array}{l}\text { Bioactive compound } \\
\text { or extract }\end{array}$ & $\begin{array}{l}\text { Pleurotus } \\
\text { species }\end{array}$ & Mechanisms of action & References \\
\hline \multirow[t]{13}{*}{ Anti-oxidative } & Lectins & P. ostreatus & $\begin{array}{l}\text { Activation of Toll-like receptor } 6 \\
\text { signal pathway of dendritic } \\
\text { cells }\end{array}$ & Ma et al. (2018) \\
\hline & \multirow[t]{7}{*}{ Polysaccharides } & Pleurotus spp. & $\begin{array}{l}\text { Improved activity after } \\
\text { polysaccharides sulphonation, }\end{array}$ & Li and Shah (2016) \\
\hline & & \multirow[t]{3}{*}{ P. ostreatus } & $\begin{array}{l}\text { Increase of the activity of SOD } \\
\text { and consequent inactivation of } \\
\text { superoxide radicals; }\end{array}$ & Islam et al. (2019) \\
\hline & & & $\begin{array}{l}\text { Increase of CAT activity by } \\
\text { upregulating gene expression } \\
\text { and consequent prevention of } \\
\text { the cells from hydrogen } \\
\text { peroxide toxicity; }\end{array}$ & Islam et al. (2019) \\
\hline & & & $\begin{array}{l}\text { Reduction of GPx activity and } \\
\text { increase of GR, GST and APx } \\
\text { activity }\end{array}$ & Islam et al. (2019) \\
\hline & & \multirow[t]{2}{*}{$\begin{array}{l}\text { P. eryngii } \\
P . \text { ostreatus }\end{array}$} & $\begin{array}{l}\text { Activation of SOD, CAT and } \\
\text { GPx and decreasing ALT in } \\
\text { mice with } \mathrm{CCI}_{4} \text {-induced liver } \\
\text { injury; }\end{array}$ & $\begin{array}{l}\text { Carrasco-González et al. } \\
\text { (2017) }\end{array}$ \\
\hline & & & $\begin{array}{l}\text { Inhibition of lipid peroxidation } \\
\text { on porcine brain homogenates }\end{array}$ & $\begin{array}{l}\text { Carrasco-González et al. } \\
\text { (2017) }\end{array}$ \\
\hline & & P. eryngii & $\begin{array}{l}\text { Inhibition of cell viability in } \\
\text { colorectal adenocarcinoma cell } \\
\text { line (HT29) }\end{array}$ & Cateni et al. (2018) \\
\hline & Phenols & P. ostreatus & $\begin{array}{l}\text { Inhibition of the growth of HL- } 60 \\
\text { cells by inducing apoptosis }\end{array}$ & $\begin{array}{l}\text { Patel et al. (2012) and } \\
\text { Vanamu (2012) }\end{array}$ \\
\hline & $\begin{array}{l}\text { Flavonoids, ß- } \\
\text { carotene, ascorbic } \\
\text { acid }\end{array}$ & P. ostreatus & $\begin{array}{l}\text { Inhibition of the growth of HL- } 60 \\
\text { cells by inducing apoptosis; } \\
\text { Reduction of ascorbate radicals }\end{array}$ & $\begin{array}{l}\text { Patel et al. (2012) and } \\
\text { Vanamu (2012) } \\
\text { Islam et al. (2019) }\end{array}$ \\
\hline & $\begin{array}{l}\alpha \text {-tocopherol } \\
\quad(\text { Vitamin E) }\end{array}$ & P. ostreatus & $\begin{array}{l}\text { Prevention of lipid peroxidation } \\
\text { in cell membranes }\end{array}$ & Islam et al. (2019) \\
\hline & Glutathione & Pleurotus spp. & $\begin{array}{l}\text { Prevention of GSH oxidation and } \\
\text { assurance of the safety of its } \\
\text { redox enzymes }\end{array}$ & Islam et al. (2019) \\
\hline & Statins (lovastatin) & P. ostreatus & $\begin{array}{l}\text { Inhibition of the plasma and } \\
\text { hepatic lipid peroxidation and } \\
\text { increase of the hepatic catalase } \\
\text { activity in high-cholesterol fed } \\
\text { rabbits }\end{array}$ & Jeon et al. (2001) \\
\hline
\end{tabular}


Table 6 continued

\begin{tabular}{|c|c|c|c|c|}
\hline Activity & $\begin{array}{l}\text { Bioactive compound } \\
\text { or extract }\end{array}$ & $\begin{array}{l}\text { Pleurotus } \\
\text { species }\end{array}$ & Mechanisms of action & References \\
\hline \multirow[t]{6}{*}{ Immunomodulatory } & \multirow[t]{5}{*}{ Polysaccharides } & Pleurotus spp. & Macrophage stimulation & Corrêa et al. (2016) \\
\hline & & P. ostreatus & $\begin{array}{l}\text { In children with RRTIs, pleuran } \\
\text { (Imunoglukan P4H®) increases } \\
\text { immunoglobulin isotypes, } \\
\text { slows down the decline of } \\
\text { T-cytotoxic lymphocytes, and e } \\
\text { increases the NK cell number }\end{array}$ & \\
\hline & & P. nebrodensis & $\begin{array}{l}\text { PN-S evaluated in RAW264.7 } \\
\text { macrophage; improved } \\
\text { phagocytosis of macrophages, } \\
\text { enhanced production of f } \\
\text { interleukin-6 (IL-6), nitric } \\
\text { oxide (NO), interferon gamma } \\
\text { (INF- } \gamma \text { ), and tumor necrosis } \\
\text { factor-a (TNF- } \alpha \text { ) in the } \\
\text { macrophages, with up- } \\
\text { regulation of mRNA } \\
\text { expressions of interleukin6 (IL- } \\
\text { 6), inducible nitric oxide } \\
\text { synthase (iNOS), interferon } \\
\text { gamma (INF- } \gamma \text { ) and tumor } \\
\text { necrosis factor- } \alpha \text { (TNF- } \alpha \text { ) }\end{array}$ & Corrêa et al. (2016) \\
\hline & & \multirow[t]{2}{*}{ P. ostreatus } & $\begin{array}{l}\text { Immunomodulatory activity } \\
\text { against infectious bursal disease } \\
\text { (IBD) in broilers; }\end{array}$ & Islam et al. (2019) \\
\hline & & & $\begin{array}{l}\text { Decrease of the toxicity of } \\
\text { cyclophosphamide in mice }\end{array}$ & Islam et al. (2019) \\
\hline & $\begin{array}{l}\text { Triterpenoids (i.e. } \\
\text { ergosterol) and } \\
\text { steroids }\end{array}$ & Pleurotus spp. & Not specified & Gargano et al. (2017) \\
\hline \multirow[t]{5}{*}{ Anti-inflammatory } & $\begin{array}{l}\text { Polysaccharides ( }(\text { - } \\
\text { glucans) }\end{array}$ & P. ostreatus & $\begin{array}{l}\text { Synergistic effect with } \\
\text { methotrexate in arthritis } \\
\text { induced rats }\end{array}$ & $\begin{array}{l}\text { Carrasco-González et al. } \\
\text { (2017) }\end{array}$ \\
\hline & \multirow[t]{2}{*}{ Aqueous extract } & \multirow[t]{2}{*}{ P. ostreatus } & $\begin{array}{l}\text { Inhibition of DNA-binding } \\
\text { activity of AP-1 and NF-kB in } \\
\text { RAW264.7 cell line and } \\
\text { suppression of the secretion of } \\
\text { TNF and IL-6 in a mice model; }\end{array}$ & $\begin{array}{l}\text { Carrasco-González et al. } \\
\text { (2017) and Patel et al. } \\
\text { (2012) }\end{array}$ \\
\hline & & & $\begin{array}{l}\text { Reduction of NO and TNF-a } \\
\text { production in murine } \\
\text { macrophage cell line } \\
\text { RAW264.7 }\end{array}$ & $\begin{array}{l}\text { Carrasco-González et al. } \\
\text { (2017) }\end{array}$ \\
\hline & Pleuran & P. eryngii & $\begin{array}{l}\text { Suppression of inflammation in } \\
\text { delayed type (type IV } \\
\text { hypersensitive) allergy response } \\
\text { in mice }\end{array}$ & $\begin{array}{l}\text { Patel et al. (2012); } \\
\text { Talkad et al. (2015) }\end{array}$ \\
\hline & $\begin{array}{l}\text { Phenols (ethanolic } \\
\text { extract) }\end{array}$ & P. eryngii & $\begin{array}{l}\text { Suppression of induced dermatitis } \\
\text { and decrease of serum level of } \\
\text { IgE and TARC as well as } \\
\text { expression of cytokines related } \\
\text { with inflammation (TNF-a, } \\
\text { INF-g, IL-4, IL-5 and IL-13) } \\
\text { and severe skin lesions in mice }\end{array}$ & $\begin{array}{l}\text { Carrasco-González et al. } \\
\text { (2017) and Ma et al. } \\
\text { (2018) }\end{array}$ \\
\hline
\end{tabular}


Table 6 continued

\begin{tabular}{|c|c|c|c|c|}
\hline Activity & $\begin{array}{l}\text { Bioactive compound } \\
\text { or extract }\end{array}$ & $\begin{array}{l}\text { Pleurotus } \\
\text { species }\end{array}$ & Mechanisms of action & References \\
\hline \multirow[t]{5}{*}{ Antihypercholesterolemic } & \multirow[t]{4}{*}{ Statins (Lovastatin) } & \multirow[t]{4}{*}{ P. ostreatus } & $\begin{array}{l}\text { Inhibition of 3-hydroxy-3- } \\
\text { methylglutaryl coenzyme A } \\
\text { (HMG CoA) reductase that } \\
\text { catalyzes the conversion of } \\
\text { HMGCoA to mevalonic acid in } \\
\text { the cholesterol synthesis } \\
\text { pathway; pleiotropic actions in } \\
\text { the cardiovascular, immune and } \\
\text { nervous systems; }\end{array}$ & Talkad et al. (2015) \\
\hline & & & $\begin{array}{l}\text { Inhibition of the plasma and } \\
\text { hepatic lipid peroxidation and } \\
\text { increase of the hepatic catalase } \\
\text { activity in high-cholesterol fed } \\
\text { rabbits; }\end{array}$ & Jeon et al. (2001) \\
\hline & & & $\begin{array}{l}\text { Acceleration of HDL, reducetion } \\
\text { of production of VLDL, LDL, } \\
\text { cholesterol; reduction of } \\
\text { cholesterol absorption and of } \\
\text { HMG-CoA reductase activity in } \\
\text { the liver; }\end{array}$ & Patel et al. (2012) \\
\hline & & & $\begin{array}{l}\text { Positively affect the coagulation } \\
\text { system and fibrinolysis }\end{array}$ & $\begin{array}{l}\text { Golak-Sivulska et al. } \\
\text { (2018) }\end{array}$ \\
\hline & Flavons (Chrysin) & P. ostreatus & $\begin{array}{l}\text { Decrease in mean blood/serum } \\
\text { levels of glucose, lipid profile } \\
\text { parameters, and hepatic marker } \\
\text { enzymes and a concomitant } \\
\text { increase in enzymatic and } \\
\text { nonenzymatic antioxidant } \\
\text { parameters in } \\
\text { hypercholesterolemic rats }\end{array}$ & Anandhi et al. (2013) \\
\hline \multirow[t]{3}{*}{$\begin{array}{l}\text { Anti-cancer and anti- } \\
\text { tumor }\end{array}$} & Cold-water extract & $\begin{array}{l}\text { P. eryngii var. } \\
\text { ferulae } \\
\text { P. nebrodensis }\end{array}$ & $\begin{array}{l}\text { On human colon cancer cells: } \\
\text { inhinition of viability of } \\
\text { HCT116 cells; promotion of } \\
\text { apoptosis; increase of Bax-to- } \\
\text { Bcl-2 messenger RNA ratio; } \\
\text { inhibition of cell migration and } \\
\text { effect on homotypic and } \\
\text { heterotypic cell-cell adhesion; } \\
\text { negative influence on protein } \\
\text { tyrosine and phosphorilation } \\
\text { levels of extracellular signal- } \\
\text { regulated kinase } 1 / 2\end{array}$ & Fontana et al. (2014) \\
\hline & \multirow[t]{2}{*}{ Methanolic extract } & \multirow[t]{2}{*}{ P. ostreatus } & $\begin{array}{l}\text { In breast cancer: suppression of } \\
\text { different cell lines proliferation } \\
\text { (MCF-7, MDA-MB-231); }\end{array}$ & Chaturvedi et al. (2018) \\
\hline & & & $\begin{array}{l}\text { Induction of expression of tumor } \\
\text { suppressor p53 and cyclin- } \\
\text { dependent kinase inhibitor p21 }\end{array}$ & $\begin{array}{l}\text { Carrasco-González et al. } \\
\text { (2017) }\end{array}$ \\
\hline
\end{tabular}


Table 6 continued

\begin{tabular}{|c|c|c|c|c|}
\hline Activity & $\begin{array}{l}\text { Bioactive compound } \\
\text { or extract }\end{array}$ & $\begin{array}{l}\text { Pleurotus } \\
\text { species }\end{array}$ & Mechanisms of action & References \\
\hline & \multirow[t]{7}{*}{ Polysaccharides } & \multirow[t]{2}{*}{ P. eryngii } & $\begin{array}{l}\text { In mice with renal cancer: } \\
\text { increase of relative thymus and } \\
\text { spleen lymphocytes } \\
\text { proliferation by elevated } \\
\text { activity of NK cells and CTL in } \\
\text { spleen; increase of serum } \\
\text { concentration level of TNF- } \alpha \\
\text { and IL-2; }\end{array}$ & Chaturvedi et al. (2018) \\
\hline & & & $\begin{array}{l}\text { Inhibition of tumor growth and } \\
\text { increased relative thymus and } \\
\text { spleen indices }\end{array}$ & Zhang et al. (2016) \\
\hline & & P. ostreatus & $\begin{array}{l}\text { Inhibition the development of } \\
\text { Ehrlich Tumor (ET) and } \\
\text { Sarcoma } 180 \text { (S-180) }\end{array}$ & $\begin{array}{l}\text { Carrasco-González et al. } \\
\text { (2017) }\end{array}$ \\
\hline & & P. nebrodensis & $\begin{array}{l}\text { Apoptosis induction by reduction } \\
\text { of mitochondrial membrane } \\
\text { potential and changes in } \\
\text { migration cell rate }\end{array}$ & $\begin{array}{l}\text { Carrasco-González et al. } \\
\text { (2017) }\end{array}$ \\
\hline & & P. ostreatus & $\begin{array}{l}\text { Cytotoxic activity towards HeLa } \\
\text { cell lines }\end{array}$ & $\begin{array}{l}\text { Golak-Sivulska et al. } \\
\text { (2018) }\end{array}$ \\
\hline & & $\begin{array}{l}P \text {. } \\
\quad \text { citrinopileatus } \\
\quad \text { Singer }\end{array}$ & $\begin{array}{l}\text { Cytotoxic activity to cervical } \\
\text { cancer cells (and no to normal } \\
\text { cells) }\end{array}$ & $\begin{array}{l}\text { Golak-Sivulska et al. } \\
\text { (2018) }\end{array}$ \\
\hline & & Pleurotus spp. & $\begin{array}{l}\text { Thymus-dependent immune } \\
\text { mechanism, which involves the } \\
\text { activation of cytotoxic } \\
\text { macrophages, monocytes, } \\
\text { neutrophiles, natural killer cells, } \\
\text { dendritic cells, and chemical } \\
\text { messengers (cytokines, such as } \\
\text { interleukins, interferons., and } \\
\text { colonystimulating factors) } \\
\text { which triggers the } \\
\text { complementary and acute phase } \\
\text { responses }\end{array}$ & Rathore et al. (2017) \\
\hline & Pleuran (ß-glucan) & P. ostreatus & $\begin{array}{l}\text { Anti-neoplastic properties against } \\
\text { different cells, including breast } \\
\text { cancer MCF-7, prostate cancer } \\
\text { cells PC-3 and colorectal HT-29 } \\
\text { cancer cells }\end{array}$ & $\begin{array}{l}\text { Golak-Sivulska et al. } \\
\text { (2018) }\end{array}$ \\
\hline & Proteins & P. ostreatus & $\begin{array}{l}\text { Therapeutic effect towards the } \\
\text { colorectal cancer cell line SW } \\
480 \text { and monocytic leukaemia } \\
\text { THP-1 by inducing their } \\
\text { apoptosis }\end{array}$ & $\begin{array}{l}\text { Golak-Sivulska et al. } \\
\text { (2018) }\end{array}$ \\
\hline & Proteins (hemolysin) & P. nebrodensis & $\begin{array}{l}\text { Strong growth inhibition } \\
\text { (IC50<40 mg/mL) against } \\
\text { five cancer cell lines (Lu-04, } \\
\text { Bre-04, HepG2, L929 and } \\
\text { HeLa) and apoptosis induction } \\
\text { in L929 and HeLa cell lines }\end{array}$ & $\begin{array}{l}\text { Carrasco-González et al. } \\
\text { (2017) }\end{array}$ \\
\hline
\end{tabular}


Table 6 continued

\begin{tabular}{|c|c|c|c|c|}
\hline Activity & $\begin{array}{l}\text { Bioactive compound } \\
\text { or extract }\end{array}$ & $\begin{array}{l}\text { Pleurotus } \\
\text { species }\end{array}$ & Mechanisms of action & References \\
\hline & Lectins & P. ostreatus & $\begin{array}{l}\text { Reduction of tumor burden in } \\
\text { Sarcoma S180 }(88.4 \%) \text { and } \\
\text { hepatoma } \mathrm{H}-22(75.4 \%) \\
\text { inoculated mice and increase of } \\
\text { the survival time }\end{array}$ & $\begin{array}{l}\text { Carrasco-González et al. } \\
\text { (2017) }\end{array}$ \\
\hline & Ethanolic extract & $\begin{array}{l}\text { P. eryngii var. } \\
\text { ferulae }\end{array}$ & $\begin{array}{l}\text { Inhibition of growth and } \\
\text { proliferation of stomach (BGC } \\
\text { 823) and melanoma (B16F10) } \\
\text { cancer cells; }\end{array}$ & $\begin{array}{l}\text { Carrasco-González et al. } \\
\text { (2017) }\end{array}$ \\
\hline & & & $\begin{array}{l}\text { Induction of cell cycle arrest in } \\
\text { G0/G1 of stomach and } \\
\text { melanoma cancer cell lines; }\end{array}$ & $\begin{array}{l}\text { Carrasco-González et al. } \\
\text { (2017) }\end{array}$ \\
\hline & & & $\begin{array}{l}\text { Delay and reduction of melanoma } \\
\text { tumor growth in a murine } \\
\text { model }\end{array}$ & $\begin{array}{l}\text { Carrasco-González et al. } \\
\text { (2017) }\end{array}$ \\
\hline & Laccase & P. cornucopiae & $\begin{array}{l}\text { Inhibition of proliferation of the } \\
\text { hepatoma cells HepG2, the } \\
\text { breast cancer cells MCF-7 }\end{array}$ & Wu et al. (2014) \\
\hline & $\begin{array}{l}\text { Monoterpenes and } \\
\text { sesquiterpenoids } \\
\text { (Pleurospiroketal) }\end{array}$ & P. cornucopiae & Cytotoxicity against cancer line & Rathore et al. (2017) \\
\hline & Triterpens & P. eryngii & $\begin{array}{l}\text { Inhibitory activity against breast } \\
\text { cancer MCF-7 cell lines in vitro }\end{array}$ & Zhang et al. (2016) \\
\hline \multirow[t]{3}{*}{ Antihypertensive } & Aqueous extract & Pleurotus spp. & $\begin{array}{l}\text { High angiotensin 1-converting } \\
\text { enzyme (ACE) inhibition }\end{array}$ & $\begin{array}{l}\text { Carrasco-González et al. } \\
\text { (2017) }\end{array}$ \\
\hline & $\begin{array}{l}\text { Hot water extract } \\
\text { D-mannitol } \\
\text { Oligopeptides }\end{array}$ & P. cornucopiae & $\begin{array}{l}\text { ACE inhibition in vitro and } \\
\text { antihypertensive effect on } \\
\text { spontaneously hypertensive rats }\end{array}$ & $\begin{array}{l}\text { Carrasco-González et al. } \\
\text { (2017) }\end{array}$ \\
\hline & Not specified & P. ostreatus & Pressure lowering activity & Patel et al. (2012) \\
\hline \multirow[t]{7}{*}{ Antiviral, antimicrobial } & Nebrodeolysin & P. nebrodensis & $\begin{array}{l}\text { Inhibition of the viral cytopathic } \\
\text { effect of HIV-1 }\end{array}$ & $\begin{array}{l}\text { Carrasco-González et al. } \\
\text { (2017) }\end{array}$ \\
\hline & Laccase & P. ostreatus & $\begin{array}{l}\text { Antiviral effects against hepatitis } \\
\text { C }\end{array}$ & $\begin{array}{l}\text { Golak-Sivulska et al. } \\
\text { (2018) }\end{array}$ \\
\hline & $\begin{array}{l}\text { Ubiquitin-like } \\
\text { protein }\end{array}$ & P. ostreatus & $\begin{array}{l}\text { Antiviral effects against HIV-1 } \\
\text { viruses }\end{array}$ & $\begin{array}{l}\text { Carrasco-González et al. } \\
\text { (2017) }\end{array}$ \\
\hline & Lectin & $P$. & $\begin{array}{l}\text { Potent effect against HIV-1 } \\
\text { reverse transcriptase activity }\end{array}$ & $\begin{array}{l}\text { Carrasco-González et al. } \\
\text { (2017) }\end{array}$ \\
\hline & $\begin{array}{l}\text { Water-soluble } \\
\text { sulfonated } \\
\text { polysaccharides }\end{array}$ & P. eryngii & $\begin{array}{l}\text { Inhibition in growth of } \\
\text { pathogenic Escherichia coli, } \\
\text { Staphylococcus aureus and } \\
\text { Listeria monocytogenes }\end{array}$ & $\begin{array}{l}\text { Carrasco-González et al. } \\
\text { (2017) }\end{array}$ \\
\hline & $\begin{array}{l}\text { Nanoparticles } \\
\text { synthesized } \\
\text { through mixing } \\
\text { queous extract with } \\
\text { silver nitrate }\end{array}$ & P. cornucopiae & Remarkable antifungal effects & $\begin{array}{l}\text { Carrasco-González et al. } \\
\text { (2017) }\end{array}$ \\
\hline & $\begin{array}{l}\text { Nanoparticles } \\
\text { synthesized } \\
\text { through mixing a } \\
\text { silver solution with } \\
\text { aqueous extract }\end{array}$ & P. ostreatus & $\begin{array}{l}\text { Inhibition in Gramnegative } \\
\text { bacteria growth }\end{array}$ & $\begin{array}{l}\text { Carrasco-González et al. } \\
\text { (2017) }\end{array}$ \\
\hline
\end{tabular}


Table 6 continued

\begin{tabular}{|c|c|c|c|c|}
\hline Activity & $\begin{array}{l}\text { Bioactive compound } \\
\text { or extract }\end{array}$ & $\begin{array}{l}\text { Pleurotus } \\
\text { species }\end{array}$ & Mechanisms of action & References \\
\hline & Aqueous extract & P. ostreatus & $\begin{array}{l}\text { Inhibition in replication of } \\
\text { Herpes simplex virus type } 1 \\
\text { in vitro }\end{array}$ & $\begin{array}{l}\text { Carrasco-González et al. } \\
\text { (2017) }\end{array}$ \\
\hline & Polysaccharides & Pleurotus spp. & $\begin{array}{l}\text { Activation of the microbial } \\
\text { autolytic system of eight } \\
\text { strains: seven autolyzing strains } \\
\text { with intensity values ranging } \\
\text { from } 2.7 \% \text { in Candida sp. to } \\
36.1 \% \text { in Saccharomyces } \\
\text { cerevisiae, while autolysis was } \\
\text { of } 1.8 \% \text { in one non-autolyzing } \\
\text { strain (Bacillus cereus) }\end{array}$ & Corrêa et al. (2016) \\
\hline & Methanolic extract & Pleurotus spp. & $\begin{array}{l}\text { Inhibition in growth of Bacillus } \\
\text { megaterium, S. aureus, E. coli, } \\
\text { Klebsiella pneumoniae, } \\
\text { C. albicans, C. glabrata, } \\
\text { species of Trichophyton and } \\
\text { Epidermophyton }\end{array}$ & Patel et al. (2012) \\
\hline & $\begin{array}{l}\text { Ether and acetone } \\
\text { extract }\end{array}$ & P. ostreatus & $\begin{array}{l}\text { Effective against } B . \text { subtilis, } \\
\text { E. coli and } S . \text { cerevisiae }\end{array}$ & Patel et al. (2012) \\
\hline & Ethanolic extract & P. ostreatus & $\begin{array}{l}\text { Inhibition in growth of Gram } \\
\text { positive bacteria (Listeria } \\
\text { innocua, B. cereus, } \\
\text { Staphylococcus aureus), Gram } \\
\text { negative bacteria (E. coli, } \\
\text { Pseudomonas aeruginosa), and } \\
\text { yeast (Candida albicans, } \\
\text { Candida } \text { sp.) }\end{array}$ & Vanamu (2012) \\
\hline & Ribonucleases & P. ostreatus & $\begin{array}{l}\text { Potentiality to neutralize HIV } \\
\text { through degradation of viral } \\
\text { genetic material }\end{array}$ & Patel et al. (2012) \\
\hline & Protein (hemolysin) & P. nebrodensis & $\begin{array}{l}\text { Anti-HIV-1 activity in CEM cell } \\
\text { culture }\end{array}$ & Patel et al. (2012) \\
\hline \multirow[t]{2}{*}{ Hyperglycemic } & Guanide & Pleurotus spp. & Anti-hypoglycemic effect & Patel et al. (2012) \\
\hline & Polysaccharides & $P$. & $\begin{array}{l}\text { Elevation of the activity of } \\
\text { glutathion peroxidase }\end{array}$ & Patel et al. (2012) \\
\hline \multirow[t]{2}{*}{ Hepatoprotective } & Polysaccharopeptides & P. ostreatus & $\begin{array}{l}\text { Alleviation of thioacetamide- } \\
\text { induced alterations, } \\
\text { inflammation, steatosis, } \\
\text { necrosis and fibrosis }\end{array}$ & Patel et al. (2012) \\
\hline & Hot-water extract & P. ostreatus & $\begin{array}{l}\text { Less leakage of alkaline } \\
\text { phosphatase, less pronounced } \\
\text { increase in hepatic } \\
\text { malondialdehyde concentration, } \\
\text { less notable reduction in hepatic } \\
\text { total protein, RNA and DNA } \\
\text { contents; in contrast, increase in } \\
\text { hepatic superoxide dismutase, } \\
\text { glutathione peroxidase and } \\
\text { glutathione reductase activities }\end{array}$ & Patel et al. (2012) \\
\hline
\end{tabular}


Table 6 continued

\begin{tabular}{|c|c|c|c|c|}
\hline Activity & $\begin{array}{l}\text { Bioactive compound } \\
\text { or extract }\end{array}$ & $\begin{array}{l}\text { Pleurotus } \\
\text { species }\end{array}$ & Mechanisms of action & References \\
\hline \multirow[t]{3}{*}{ Anti-Ageing } & $\begin{array}{l}\text { Aqueous, } \\
\text { methanolic, and } \\
\text { acetonic extracts }\end{array}$ & Pleurotus spp. & $\begin{array}{l}\text { Anti-tyrosinase, anti- } \\
\text { hyaluronidase, anti-collagenase } \\
\text { and anti-elastase activity }\end{array}$ & Taofiq et al. (2016) \\
\hline & Mushroom powder & $\begin{array}{l}\text { P. ostreatus and } \\
P . \text { eryngii }\end{array}$ & $\begin{array}{l}\text { Significant bifidogenic effect and } \\
\text { strong lactogenic effect, } \\
\text { respectively }\end{array}$ & Mitsou et al. (2020) \\
\hline & Extracts & P. ostreatus & $\begin{array}{l}\text { Lowered levels of } \\
\text { malondialdehyde, a } \\
\text { polyunsaturated lipid and an } \\
\text { electrophilic mutagen, on } \\
\text { administration of mushroom } \\
\text { extract to aged rats, and } \\
\text { subsequent reaction with } \\
\text { deoxyadenosine and } \\
\text { deoxyguanosine in DNA, } \\
\text { forming a DNA adduct }\end{array}$ & Patel et al. (2012) \\
\hline
\end{tabular}

glycation of a target protein (Gallotti and Lavelli 2020). Besides polysaccharides from cultivated Rubroboletus sinicus (W.F. Chiu) Kuan Zhao \& Zhu L. Yang showed high inhibitory effects on glycation (Liping et al. 2016). A medium-molecular-weight fraction obtained by sclerotia of Lignosus rhinocerus (Cooke) Ryvarden contain bioactive compounds which exhibit potent anti-glycation activity and is eligible for preventing diabetic complications by Advanced Glycation End Products (AGE) (Yap et al. 2018).

\section{Mycochemicals in functional foods}

As mentioned, today's concept of food is changing, becoming more complex. "Functional food" namely conventional food is consumed as part of the daily diet.

This type of food positively affects one or more physiological functions of the human body is proven; therefore, in addition to the nutritional intake, they contribute to maintaining the state of wellness, improving health, and reducing the risk of disease.

This concept is flanked by that of "food supplements" which, compared to the previous ones, constitute a concentrated source of nutrients or substances with nutritional and/or physiological effect; they are marketed in various dose forms, including tablets, capsules, gummies, and powders, as well as drinks and energy bars and aim to provide nutrients to fulfil the nutritional requirement of an individual.

Mushrooms are functional food, because of their nutritional features: they are hypocaloric and a good source of high-quality dietary fiber. Their carbohydrate content as glycogen (and not of starch) is low.

They also have significative digestible proteins and all the essential amino acids required by an adult and often deficient in plants, as well as various vitamins and mineral elements in content often at higher levels than vegetables.

Therefore, in addition to taking a leading role in diseases such as hypertension, cholesterol, obesity, etc.) and they provide an efficient alternative in areas with widespread malnutrition.

Mushrooms show potential for obtaining fortified foods, improving nutrition, and adding health benefits.

Although knowledge about the therapeutic properties of mushrooms is now quite extensive, their incorporation into foods to produce fortified foods is not so widespread today. However, various research has been undertaken in recent years in this direction, demonstrating how the addition of extracts or compounds of medicinal mushrooms, such as Pleurotus spp., into processed food, increases their sensory, nutritional, functional, or nutraceutical features 
Table 7 Bioactivities of some Italian wild and cultivated mushrooms

\begin{tabular}{llll}
\hline $\begin{array}{l}\text { Mushrooms } \\
\text { species }\end{array}$ & $\begin{array}{l}\text { Bioactive } \\
\text { compound or } \\
\text { extract }\end{array}$ & Activity and mechanisms & References \\
& & & \\
\hline
\end{tabular}

Agaricus
bisporus

Lectin (ABL)

Mannose-binding
protein (Abmb)
Methanolic and
aqueous extracts
Polysaccharide
Fruiting body
extracts

\section{Antineoplastic}

Antiviral

Scavenging activity, metal chelating activity, reducing power; antihypoxic activity

Anticancer

Inhibition of proliferation of cancerous human epithelial colon cells (HT29) in vitro

Inhibition of MCF-7 (breast cancer cells) and Caco-2 cancer cell proliferation in vitro

Suppressed proliferation of retinal pigment epithelium (RPE) cells, and subsequent lowering of proliferative vitreoretinopathy;

Slows down proliferation of human ocular fibroblast and reduces collagen lattice contraction in vitro

Strong inhibition against human immunodeficiency virus type-1 (HIV-1) reverse transcriptase (IC50 of $8 \mu \mathrm{M}$ ) in vitro;

Anticancer

Inhibits proliferation of MCF-7 breast cancer cells at $12.5 \mu \mathrm{M}$ and arrests growth at lower concentrations in vitro

Anti-inflammatory, analgesic, antipyretic, antioxidative and antimicrobial (in mice and/or in vitro)

Immunostimulatory and antitumor bioactivity in vivo and in vitro

Immunostimulating On activated human peripheral blood mononuclear cells (PBMCs) and induced synthesis of interferon gamma (IFN- $\gamma$ )

Antitumor

Inhibition on cell proliferation of HL-60 leukemia cells and other leukemia human cell lines via the induction of apoptosis;

Suppression of aromatase activity, inhibition on breast cancer cell proliferation, and decrease in mammary tumor formation in vivo

\begin{tabular}{|c|c|c|}
\hline UFA & Antitumor & Inhibition on aromatase activity \\
\hline Arginine & Antitumor & Delay of tumor growth and metastasis \\
\hline \multirow[t]{2}{*}{ Lovastatin } & Antitumor & $\begin{array}{l}\text { Anti-cancer effects in the triple-negative breast } \\
\text { cancer cell line MDA-MB-231 }\end{array}$ \\
\hline & Antihyperlipidemic & $\begin{array}{l}\text { Reduction of cholesterol level in serum and/or } \\
\text { liver }\end{array}$ \\
\hline Sterols & Antihyperlipidemic & $\begin{array}{l}\text { Reduction in cholesterol absorption and thereby } \\
\text { lowered plasma cholesterol and LDL } \\
\text { cholesterol }\end{array}$ \\
\hline $\begin{array}{l}\text { Fruiting body } \\
\text { extracts }\end{array}$ & Antidiabetic & $\begin{array}{l}\text { Decreased severity of streptozotocin-induced } \\
\text { diabetes in rat }\end{array}$ \\
\hline$\alpha$-glucans & Antidiabetic & $\begin{array}{l}\text { Lowered producing lipopolysaccharide-induced } \\
\text { TNFa }\end{array}$ \\
\hline $\begin{array}{l}\text { Polysaccharides and } \\
\text { phenolics }\end{array}$ & \multicolumn{2}{|c|}{$\begin{array}{l}\text { Scavenging of superoxide, hydroxyl and DPPH radicals and hydrogen } \\
\text { peroxide, enhancement of the activities of antioxidant enzymes in } \\
\text { sera, liver, and heart of mice }\end{array}$} \\
\hline
\end{tabular}

Li et al. (2015)

Ismaya et al. (2020)

Ismaya et al. (2020)

Ismaya et al. (2020)

Ismaya et al. (2020)

Bose et al. (2019)

Atila et al. (2017)

Atila et al. (2017)

Atila et al. (2017)

Atila et al. (2017)

Atila et al. (2017)

Atila et al. (2017)

Atila et al. (2017)

Atila et al. (2017)

Atila et al. (2017)

Atila et al. (2017)

Atila et al. (2017)

Zhang et al.

(2016) 
Table 7 continued

\begin{tabular}{|c|c|c|c|c|}
\hline \multirow{2}{*}{$\begin{array}{l}\text { Mushrooms } \\
\text { species }\end{array}$} & \multirow{2}{*}{$\begin{array}{l}\text { Bioactive } \\
\text { compound or } \\
\text { extract }\end{array}$} & \multicolumn{2}{|c|}{ Activity and mechanisms } & \multirow{2}{*}{$\begin{array}{l}\text { References } \\
\begin{array}{c}\text { Chaturvedi et al. } \\
(2018)\end{array}\end{array}$} \\
\hline & & Antitumor & $\begin{array}{l}\text { Involvement of NK cells and induction ofgene } \\
\text { expression of nitric oxide by transcription } \\
\text { factor and NF-kappa B downstream signalling, } \\
\text { interferon- } \gamma \text { and interleukin, that activate NK } \\
\text { cells }\end{array}$ & \\
\hline \multirow[t]{9}{*}{ Boletus edulis } & $\begin{array}{l}\text { Polysaccharide } \\
\text { (BEP) }\end{array}$ & Immunomodulatory & $\begin{array}{l}\text { Reduction of tumor mass in Renca tumor } \\
\text { bearing mice; stimulation of splenocytes } \\
\text { proliferation, increase in NK cell and CTL } \\
\text { activities in spleen }\end{array}$ & $\begin{array}{l}\text { Wang et al. } \\
\qquad(2014 a)\end{array}$ \\
\hline & Polysaccharides & \multicolumn{2}{|l|}{ Antioxidant activity } & $\begin{array}{l}\text { Zhang et al. } \\
\text { (2018) }\end{array}$ \\
\hline & \multirow[t]{3}{*}{ Lectin } & \multirow{2}{*}{\multicolumn{2}{|c|}{$\begin{array}{l}\text { Hemagglutinating activity; } \\
\text { Mitogenic activity in mouse splenocytes; }\end{array}$}} & Zheng et al. \\
\hline & & & & (2007) \\
\hline & & Antiviral & $\begin{array}{l}\text { Inhibition of human immunodeficiency virus-1 } \\
\text { reverse transcriptase }\end{array}$ & \\
\hline & Phenolics & Antioxidative & Inhibition of lipid oxidation & Ma et al. (2018) \\
\hline & $\begin{array}{l}\text { Prepared for } \\
\text { consumption } \\
\text { mushrooms }\end{array}$ & Antioxidative & $\begin{array}{l}\text { High antioxidant activity against ABTS, DPPH } \\
\text { and in FRAP assay }\end{array}$ & $\begin{array}{l}\text { Jaworska et al. } \\
\text { (2015) }\end{array}$ \\
\hline & $\begin{array}{l}\text { Ethanolic and hot } \\
\text { water extracts }\end{array}$ & Antioxidative & & Tsai et al. (2007) \\
\hline & $\begin{array}{l}\text { Polysaccharide } \\
\text { (BPS) }\end{array}$ & Antidiabetic & $\begin{array}{l}\text { Inhibition of oxidative stress and inflammation } \\
\text { in rats liver }\end{array}$ & Xiao et al. (2019) \\
\hline \multirow[t]{8}{*}{$\begin{array}{l}\text { Coprinus } \\
\text { comatus }\end{array}$} & Ethyl acetate extract & Antitumor & $\begin{array}{l}\text { Activity against ovarian cancer cell lines } \\
\text { SKOV-3 and SW- } 626 \text { and reduced viability of } \\
\text { human ovarian cancer cells; }\end{array}$ & $\begin{array}{l}\text { Venturella et al. } \\
\text { (2019) }\end{array}$ \\
\hline & & & $\begin{array}{l}\text { Apoptosis induction in ovarian cancer cells (ES- } \\
\text { 2) via both extrinsic and intrinsic pathways }\end{array}$ & \\
\hline & Aqueous suspension & Antioxidative & $\begin{array}{l}\text { increase of antioxidative status of liver } \\
\text { homogenate and prevention of histological } \\
\text { changes in liver cross sections in oxidative } \\
\text { stressed rats }\end{array}$ & $\begin{array}{l}\text { Popović et al. } \\
\text { (2010) }\end{array}$ \\
\hline & $\begin{array}{l}\text { Fruiting body } \\
\text { extract }\end{array}$ & Antiaggregant & $\begin{array}{l}\text { Inhibition of platelet aggregation induced by } \\
\text { ADP via a P2Y12 receptor }\end{array}$ & $\begin{array}{l}\text { Poniedziałek } \\
\text { et al. (2019) }\end{array}$ \\
\hline & $\begin{array}{l}\text { Ethanolic and water } \\
\text { extract }\end{array}$ & \multicolumn{2}{|c|}{ Antioxidant and scavenging property } & Li et al. (2010) \\
\hline & Laccase & Antiviral & $\begin{array}{l}\text { Inhibition of human immunodeficiency virus } \\
\text { type } 1 \text { (HIV-1) reverse transcriptase }\end{array}$ & Ma et al. (2018) \\
\hline & & Antitumor & $\begin{array}{l}\text { Suppression of proliferation of tumor cell lines } \\
\text { HepG } 2 \text { and MCF7 }\end{array}$ & Ma et al. (2018) \\
\hline & $\begin{array}{l}\gamma \text {-aminobutyric acid } \\
\text { (GABA) }\end{array}$ & Hypotensive & & Tsai et al. (2007) \\
\hline \multirow[t]{2}{*}{$\begin{array}{r}\text { Cyclocybe } \\
\text { aegerita }\end{array}$} & Polysaccharides & Anti-ageing & $\begin{array}{l}\text { Increased cell viability and } \beta \text {-Gal viability, } \\
\text { prevention of G1-phase cell-cycle arrest, } \\
\text { decreased mitochondrial membrane potential }\end{array}$ & Liu et al. (2020c) \\
\hline & & Antidiabetic & $\begin{array}{l}\text { Inhibition of iNOS expression, reduction of } \\
\text { blood glucose level }\end{array}$ & Liu et al. (2020c) \\
\hline
\end{tabular}


Table 7 continued

\begin{tabular}{|c|c|c|c|c|}
\hline \multirow{2}{*}{$\begin{array}{l}\text { Mushrooms } \\
\text { species }\end{array}$} & \multirow{2}{*}{$\begin{array}{l}\text { Bioactive } \\
\text { compound or } \\
\text { extract }\end{array}$} & \multicolumn{2}{|c|}{ Activity and mechanisms } & \multirow{2}{*}{$\begin{array}{l}\text { References } \\
\text { Lin et al. (2017) }\end{array}$} \\
\hline & & Anti-angiogenic & $\begin{array}{l}\text { In vitro inhibition of vascular endothelial growth } \\
\text { factor (VEGF)-induced proliferation } \\
\text { inHUVECs; down-regulation of intracellular } \\
\text { reactive oxygen species (ROS) level and } \\
\text { VEGF secretion in Caco-2 cells; decrease in } \\
\text { the migration of endothelial cells (ECs) }\end{array}$ & \\
\hline & Proteins & Antitumor & $\begin{array}{l}\text { Against different tumor cell lines; stimulation of } \\
\text { immune response; enhanced splenocyte } \\
\text { cytotoxic activity and mRNA level of } \\
\text { cytokines in mice }\end{array}$ & $\begin{array}{l}\text { Liang et al. } \\
\text { (2011) }\end{array}$ \\
\hline & $\begin{array}{l}\text { Ageritin (ribotoxin- } \\
\text { like protein) }\end{array}$ & Antitumor & $\begin{array}{l}\text { Cytotoxicity and cell death promoting effects } \\
\text { towards CNS model cell lines (SK-N-BE(2)-C, } \\
\text { U-251 and C6); extrinsic apoptotic pathway by } \\
\text { initially activating caspase-8 }\end{array}$ & $\begin{array}{l}\text { Landi et al. } \\
\text { (2017b) and } \\
\text { Ruggiero et al. } \\
\text { (2018) }\end{array}$ \\
\hline & Galectin (AAL) & Antitumor & $\begin{array}{l}\text { Anti-metastasis activity in breast cancer, anti- } \\
\text { proliferation activity against } 4 \mathrm{~T} 1 \text { cells }\end{array}$ & $\begin{array}{l}\text { Yang et al. } \\
\text { (2018) }\end{array}$ \\
\hline & Ceramide & Antitumor & $\begin{array}{l}\text { Inhibition of the proliferation of stomach, breast } \\
\text { and CNS cancer cell lines in vitro }\end{array}$ & $\begin{array}{l}\text { Diyabalanage } \\
\text { et al. (2008) }\end{array}$ \\
\hline & & Anti-inflammatory & $\begin{array}{l}\text { Inhibition on cyclooxygenase enzymes COX-1 } \\
\text { and }-2\end{array}$ & \\
\hline & $\begin{array}{l}\text { Hot-water and } \\
\text { ethanolic extracts }\end{array}$ & Antioxidative & & $\begin{array}{l}\text { Tsai et al. } \\
(2006,2007)\end{array}$ \\
\hline & $\begin{array}{l}\text { Methanolic extract } \\
\text { (FAF) }\end{array}$ & Antioxidative and $c$ & clooxygenase (COX) enzyme inhibitory activity & $\begin{array}{l}\text { Zhang et al. } \\
\text { (2003) }\end{array}$ \\
\hline \multirow{5}{*}{$\begin{array}{l}\text { Lactarius } \\
\text { deliciosus }\end{array}$} & \multirow[t]{3}{*}{ Methanolic extract } & \multicolumn{2}{|c|}{ Antioxidant and free radical scavenging activity } & Kosanić et al. \\
\hline & & Antimicrobial & $\begin{array}{l}\text { Inhibition of bacteria (Bacillus cereus, B. } \\
\text { subtilis, Proteus mirabilis, E. coli, } \\
\text { Staphylococcus aureus) and fungi (Aspergillus } \\
\text { niger, Penicillium expansum, P. chrysogenum, } \\
\text { Alternaria alternata, Trichoderma } \\
\text { viride, Cladosporium cladosporioides, Mucor } \\
\text { mucedo, Fusarium oxysporum, Candida } \\
\text { albicans) }\end{array}$ & (2016) \\
\hline & & Anticancer & $\begin{array}{l}\text { Growth inhibition in HeLa, A549 and LS174 } \\
\text { cell lines }\end{array}$ & \\
\hline & Aqueous and/or & Antioxidative & & $\mathrm{Xu}$ et al. (2019) \\
\hline & ethanol extract & Antihyperglycemic & $\begin{array}{l}\text { Inhibitory effects on } \alpha \text {-amylase and } \alpha \text { - } \\
\text { glucosidase }\end{array}$ & \\
\hline \multirow{3}{*}{$\begin{array}{l}\text { Macrolepiota } \\
\text { procera }\end{array}$} & \multirow[t]{3}{*}{ Methanolic extract } & \multicolumn{2}{|c|}{ Antioxidant and free radical scavenging activity; } & Kosanić et al. \\
\hline & & Antimicrobial & $\begin{array}{l}\text { Inhibition of bacteria (Bacillus cereus, B. } \\
\text { subtilis, Proteus mirabilis) and fungi } \\
\text { (Aspergillus niger, Penicillium expansum, } \\
\text { Alternaria alternata, Trichoderma } \\
\text { viride, Cladosporium cladosporioides, } \\
\text { Fusarium oxysporum, Candida albicans) }\end{array}$ & (2016) \\
\hline & & Anticancer & $\begin{array}{l}\text { Growth inhibition in HeLa, A549 and LS174 } \\
\text { cell lines }\end{array}$ & \\
\hline
\end{tabular}


Table 7 continued

\begin{tabular}{|c|c|c|c|c|}
\hline $\begin{array}{l}\text { Mushrooms } \\
\text { species }\end{array}$ & $\begin{array}{l}\text { Bioactive } \\
\text { compound or } \\
\text { extract }\end{array}$ & \multicolumn{2}{|c|}{ Activity and mechanisms } & References \\
\hline & Mushroom extract & \multicolumn{2}{|l|}{ Antioxidant activity } & $\begin{array}{l}\text { Islam et al. } \\
\text { (2019) }\end{array}$ \\
\hline & $\begin{array}{l}\text { Powder of freeze, } \\
\text { dried and } \\
\text { irradiated } \\
\text { mushrooms }\end{array}$ & \multicolumn{2}{|l|}{ Antioxidant activity } & $\begin{array}{l}\text { Fernandes et al. } \\
\text { (2013) }\end{array}$ \\
\hline $\begin{array}{l}\text { Russula } \\
\quad \text { virescens }\end{array}$ & $\begin{array}{l}\text { Polysaccharide } \\
\text { (RVP) }\end{array}$ & \multirow{2}{*}{\multicolumn{2}{|c|}{ Antioxidant activity }} & $\begin{array}{l}\text { Sun et al. } \\
\quad(2010 a, b)\end{array}$ \\
\hline & Phenolics & & & \\
\hline $\begin{array}{l}\text { Russula } \\
\text { cyanoxantha }\end{array}$ & Phenolics & \multicolumn{2}{|l|}{ Antioxidant activity } & \\
\hline \multirow[t]{3}{*}{$\begin{array}{l}\text { Tuber } \\
\text { magnatum }\end{array}$} & \multirow[t]{3}{*}{$\begin{array}{l}\text { Water and/or } \\
\text { methanol extract }\end{array}$} & Anti-inflammatory & $\begin{array}{l}\text { Inhibition of COX-1 and 12-LOX pathway } \\
\text { products synthesis }\end{array}$ & $\begin{array}{l}\text { Beara et al. } \\
\quad(2014)\end{array}$ \\
\hline & & Antitumor & $\begin{array}{l}\text { Cytotoxicity against some tumour cell lines } \\
\text { (HeLa, MCF7, HT-29) }\end{array}$ & \\
\hline & & \multicolumn{2}{|l|}{ Antioxidative } & \\
\hline \multirow[t]{4}{*}{$\begin{array}{l}\text { Tuber } \\
\text { melanosporum }\end{array}$} & Polysaccharides & Antitumor & $\begin{array}{l}\text { Activities against A549, HCT-116, HepG2, HL- } \\
60 \text {, and SK-BR-3 cells lines }\end{array}$ & $\begin{array}{l}\text { Lee et al. (2020) } \\
\text { and Patel et al. } \\
\text { (2017) }\end{array}$ \\
\hline & $\begin{array}{l}\text { Anandamide } \\
\text { (endocannabinoid) }\end{array}$ & Antitumor & $\begin{array}{l}\text { Inhibited on angiogenesis of highly invasive and } \\
\text { metastatic breast cancer cells; }\end{array}$ & $\begin{array}{l}\text { Lee et al. (2020) } \\
\text { and Patel et al. }\end{array}$ \\
\hline & & & $\begin{array}{l}\text { Stimulation of non-apoptotic cell death in COX- } \\
2 \text { overexpressed colorectal cancer cells }\end{array}$ & (2017) \\
\hline & Methanolic extract & Antioxidative & Inhibition of lipid oxidation & $\begin{array}{l}\text { Villares et al. } \\
\text { (2012) }\end{array}$ \\
\hline \multirow[t]{5}{*}{ Tuber spp. } & Flavonoids & \multirow{2}{*}{\multicolumn{2}{|c|}{$\begin{array}{l}\text { Antioxidative, anti-inflammatory, anti-mutagenic, and anticancer } \\
\text { Antioxidant, anti-inflammatory, and antihyperlipidemic }\end{array}$}} & Lee et al. (2020) \\
\hline & Ergosterol & & & Lee et al. (2020) \\
\hline & Oleic acid & Antitumor & $\begin{array}{l}\text { Suppression of overexpression of HER2; } \\
\text { induction of cancer cell apoptosis }\end{array}$ & Lee et al. (2020) \\
\hline & & \multicolumn{2}{|l|}{ Hypocholesterolemic } & \\
\hline & L-tyrosine & \multicolumn{2}{|l|}{ Anti-depressant } & Patel et al. (2017) \\
\hline
\end{tabular}

(Carrasco-González et al. 2017; Reis et al. 2017; Lavelli et al. 2018; Salehi 2019).

The potential of mushroom powder to enrich baked (bread, biscuits, and cakes) and extruded (breakfast cereals, snacks) cereal products with fiber for the production of fitness-promoting foods (low in calories, cholesterol, and fat) is remarkable. Gaglio et al. (2019) evaluated the effect of partially replacing wheat flour with $P$. eryngii powder (5 and $10 \% \mathrm{w} / \mathrm{w}$ ) in baked bread; the fermentation process has not undergone any alterations, the final product had positive physical and organoleptic characteristics with the advantage of having higher concentrations of thiamin, riboflavin and pantothenic acid and, more importantly, supplied biotin, cobalamin, and cholecalciferol generally absent in wheat bread.

Another study on P. eryngii (Kim et al. 2010) demonstrated how biscuits supplemented with mushroom powder showed significantly increased total phenol compound content, ferric reducing antioxidant power (FRAP), and DPPH radical scavenging activity, maintaining appreciable organoleptic and rheological 
properties. Also, A. bisporus powder was evaluated by Kumar and Barmanray (2007) as a supplement for fortified biscuits, that showed a significantly higher protein content with good overall acceptability. $P$. eryngii $\beta$-glucan-rich fractions (BGRFs) have been tested as an ingredient of wheat semolina pasta (Kim et al. 2016), obtaining the best results in terms of qualitative, textural, and sensory characteristics with a concentration of $4 \%$, in addition to higher beneficial properties.

Studies carried out by Lu et al. $(2016,2018)$ have shown that the inclusion of powdered A. bisporus and B. edulis mushrooms in wheat semolina allows to obtain a pasta with more fibre and less starch, therefore with a lower glycemic power and higher antioxidant properties. Equally positive results have been achieved in snack products supplemented with A. bisporus and B. edulis powder (Singla et al. 2009; Lu et al. 2020).

Mushrooms have also been tested to enrich other types of foods. Exploiting the high fiber and protein content, A. bisporus powder has been used for the production of functional meat products with better emulsion characteristics and textural properties (Kurt and Gençcelep 2018).

Barros et al. (2011) demonstrated that B. edulis extracts protect beef burgers from lipid peroxidation and also give them greater antioxidant potential, while a study by Stojković et al. (2015) revealed that the methanolic extract of $B$. aureus Schaeff. helps to increase the shelf-life of meat, protecting it from food contaminating bacteria. An interesting application of Pleurotus spp. concerns fortified dairy foods. A study carried out by Pelaes Vital et al. (2015) showed how adding $P$. ostreatus aqueous extract to milk leads to the production of yogurt with an increased Streptococcus thermophiles and Lactobacillus bulgaricus CFU, polyphenols content, and enhanced antioxidant activity, and improved rheological properties.

Soy milk added with polysaccharide extract of $P$. eryngii shows an increased vitality of Bifidobacterium longum and reduced $\mathrm{pH}$ during yogurt fermentation ( $\mathrm{Li}$ and Shah 2016). The incorporation of $P$. ostreatus in the cheese mixture as a fresh and dried mushroom has resulted in cream cheese with higher ash, protein, and mineral contents, as well as an increase in lipolytic and proteolytic bacteria and excellent storage performances (Khider et al. 2017). The incorporation of $C$. aegerita powder has also proven to increase the antioxidant properties of cream cheese, as well as giving it more appreciated sensory characteristics (Petrović et al. 2015). The extract of A. bisporus has proved effective in preserving yogurt from the pathogen Listeria monocytogenes (Stojković et al. 2014). Moreover, a study conducted by Proserpio et al. (2019) involved the addition of P. ostreatus powder in vegetable soups, resulting in a product with a higher content of bioactive $\beta$-glucans and good palatability at a concentration of $2 \%$.

Although the results obtained so far are remarkably promising, much remains to be done; in addition to enlarging the fans of mushroom species potentially valuable as food fortifiers, further study is needed on various parameters such as the bioaccessibility of bioactive compounds, especially considering the different production steps that a processed product undergoes, their bioavailability, possible interactions with the food matrix and possible interferences with the bioavailability or absorption of the various nutrients. This path is even necessary so that their relevance and effectiveness can be recognized and thus ruled also from a legislative point of view, in order to achieve the important objective of large-scale marketing of healthy food products that promote physical well-being.

\section{Conclusions}

The review reveals the great potential of mushrooms in the production of mycochemicals that represent a rich source of drugs, nutraceutical, and functional food. The mycochemicals isolated and identified from mushrooms are bioactive compounds belonging to different chemical classes.

The present study describes the chemical composition of Italian wild and cultivated mushrooms as a source of bioactive metabolites for further development of drugs.

The application of mushrooms for health purposes is recent in the Western areas but still slowly growing. In European markets, nutraceuticals are not yet a widespread and established product and, in most cases, imported from Asia. Due to the vacant and imprecise regulations, we often have to deal with nutraceuticals of dubious composition and without guaranteed quality standards. Most Western countries, moreover, follow the rules of the WHO, DSHEA (Dietary 
Supplement Health and Education Act), and EFSA (European Food Safety Agency) in which plant or MM extracts are dietary supplements. So clinical studies are not required before their introduction in the market. These markets, therefore, have enormous potential for development, which can only be achieved through intensive research and the spreading of knowledge to educate and raise awareness in this respect among consumers and society because very few people are still aware of the benefits and importance of MMs.

The research on medicinal mushrooms in Italy needs to undertake more extensive studies to ascertain the medicinal properties of the mushroom species.

The final objective of the newborn Italian Medicinal Mushrooms Society is to improve the quality of life and the state of health of people, also in the vision of an increasingly integrated medicine. The animal farming sector could also benefit from the inclusion of mushrooms, MMs supplements, or fortified feed in the animal diet, as well as, for example, from the possibility of using alternative and natural antibiotics and antivirals.

Besides, mushrooms represent an economic crop that fits with the circular economy and the recycling of agro-industrial wastes. Finally, mushrooms are also able to provide nutritional support in areas with malnutrition and economically depressed areas.

Author contributions All authors contributed equally to this work and have read and agreed to the published version of the manuscript.

Funding Open access funding provided by Università degli Studi di Bari Aldo Moro within the CRUI-CARE Agreement. This research received no external funding.

\section{Declarations}

Conflict of interest The authors declare no conflicts of interest.

Open Access This article is licensed under a Creative Commons Attribution 4.0 International License, which permits use, sharing, adaptation, distribution and reproduction in any medium or format, as long as you give appropriate credit to the original author(s) and the source, provide a link to the Creative Commons licence, and indicate if changes were made. The images or other third party material in this article are included in the article's Creative Commons licence, unless indicated otherwise in a credit line to the material. If material is not included in the article's Creative Commons licence and your intended use is not permitted by statutory regulation or exceeds the permitted use, you will need to obtain permission directly from the copyright holder. To view a copy of this licence, visit http://creativecommons.org/licenses/by/4.0/.

\section{References}

Alshammaa DAS (2017) Phytochemical investigation and quantitative comparison of Ergosterol between Agaricus bisporus and Pleurotus ostreatus by HPLC and GC-MS methods. Int J Pharm Sci Rev Res 44(2):215-220

Anandhi R, Annadurai T, Anitha TS et al (2013) Antihypercholesterolemic and antioxidative effects of an extract of the oyster mushroom, Pleurotus ostreatus, and its major constituent, chrysin, in Triton WR-1339-induced hypercholesterolemic rats. J Physiol Biochem 69:313-323. https://doi.org/10.1007/s13105-012-0215-6

Antunes F, Marçal S, Taofiq O et al (2020) Valorization of mushroom by-products as a source of value-added compounds and potential applications. Molecules 25:2672. https://doi.org/10.3390/molecules25112672

Aprea E, Romano A, Betta E et al (2015) Volatile compound changes during shelf life of dried Boletus edulis: comparison between SPME-GC-MS and PTR-ToF-MS analysis. J Mass Spectrom 50:56-64. https://doi.org/10.1002/jms. 3469

Arbaayah HH, Umi KY (2013) Antioxidant properties in the oyster mushrooms (Pleurotus spp.) and split gill mushroom (Schizophyllum commune) ethanolic extracts. Mycosphere 4:661-673

Atila F, Owaid MN, Shariati MA (2017) The nutritional and medical benefits of Agaricus bisporus: a review. J Microbiol Biotech Food Sci 7(3):281-286. https://doi.org/10. 15414/jmbfs.2017/18.7.3.281-286

Ayaz FA, Torun H, Özel A et al (2011) Nutritional value of some wild edible mushrooms from the Black Sea region (Turkey). Turk J Biochem 36(4):385-393

Barros LL, Cruz T, Baptista P et al (2008) Wild and commercial mushrooms as source of nutrients and nutraceuticals. Food Chem Toxicol 46:2742-2747. https://doi.org/10.1016/j.fct. 2008.04.030

Barros L, Barreira J, Grangeia C et al (2011) Beef burger patties incorporated with Boletus edulis extracts: lipid peroxidation inhibition effects. Eur J Lipid Sci Technol 113(6):737-743. https://doi.org/10.1002/ejlt.201000478

Beara IN, Lesjak MM, Četojević-Simin DD et al (2014) Phenolic profile, antioxidant, anti-inflammatory and cytotoxic activities of black (Tuber aestivum Vittad.) and white (Tuber magnatum Pico) truffles. Food Chem 165:460-466. https://doi.org/10.1016/j.foodchem.2014.05.116

Bederska-Łojewska D, Świątkiewicz S, Muszyńska B (2017) The use of Basidiomycota mushrooms in poultry nutrition—a review. Anim Feed Sci Technol 230:59-69. https:// doi.org/10.1016/j.anifeedsci.2017.06.001

Bellesia F, Pinetti A, Bianchi A et al (1988) The volatile organic compounds of black truffle (Tuber melanosporum Vitt.) from middle Italy. Flavour Frag J 13:56-58. https://doi.org/ 10.1002/(sici)1099-1026(199801/02)13:1\%3c56::aidffj692\%3e3.0.co;2-x 
Bellesia F, Pinetti A, Tirillini B et al (2001) Temperature-dependent evolution of volatile organic compounds in Tuber borchii from Italy. Flavour Frag J 16:1-6. https://doi.org/ 10.1002/1099-1026(200101/02)16:1\%3c1::aid-ffj936\% 3e3.0.co; $2-y$

Biscaia SMP, Carbonero ER, Bellan DL et al (2017) Safe therapeutics of murine melanoma model using a novel antineoplasic, the partially methylated mannogalactan from Pleurotus eryngii. Carbohydr Polym 178:95-104. https://doi.org/10.1016/j.carbpol.2017.08.117

Bobovčák M, Kuniaková R, Gabriž J et al (2010) Effect of Pleuran ( $\beta$-glucan from Pleurotus ostreatus) supplementation on cellular immune response after intensive exercise in elite athletes. Appl Physiol Nutr Metab 35(6):755-762. https://doi.org/10.1139/h10-070

Bonanno A, Di Grigoli A, Vitale F et al (2019) Effects of diets supplemented with medicinal mushroom myceliated grains on some production, health, and oxidation traits of dairy ewes. Int J Med Mushrooms 21(1):89-103. https://doi.org/ 10.1615/IntJMedMushrooms.2018029327

Bose S, Mandal SK, Hossain P et al (2019) Phytochemical and pharmacological potentials of Agaricus bisporus. Res J Pharm Technol 12(8):3811-3817. https://doi.org/10.5958/ 0974-360x.2019.00653.x

Bovi M, Cenci L, Perduca M et al (2013) BEL $\beta$-trefoil: a novel lectin with antineoplastic properties in King bolete (Boletus edulis) mushrooms. Glycobiology 23(5):578-592. https://doi.org/10.1093/glycob/cws164

Bulam S, Üstün NS, Pekşen A (2019) Evaluation of nutritional and medicinal values of edible wild and cultivated Pleurotus ostreatus. Turk J Agric Food Sci Technol 7(12):2054-2061. https://doi.org/10.24925/turjaf.v7i12. 2054-2061.2730

Butkhup L, Samappito W, Jorjong S (2018) Evaluation of bioactivities and phenolic contents of wild edible mushrooms from northeastern Thailand. Food Sci Biotechnol 27(1):193-202. https://doi.org/10.1007/s10068-017-02375

Çağlarirmak N (2011) Edible mushrooms: an alternative food item. In: Savoie JM, Foulongne-Oriol M, Largeteau M, Barroso G (eds) ICMBMP 2011. Proceedings of the 7th international conference on mushroom biology and mushroom products; October 4-7; Arcachon, France, pp 548-554

Carrasco-González JA, Serna-Saldívar SO, Gutíerrez-Uribe JA (2017) Nutritional composition and nutraceutical properties of the Pleurotus fruiting bodies: potential use as food ingredient. J Food Compost Anal 58:69-81. https://doi.org/ 10.1016/j.jfca.2017.01.016

Cateni F, Zacchigna M, Caruso Bavisotto C et al (2018) Structural characterization of polysaccharides of a productive strain of the culinary-medicinal king oyster mushroom, Pleurotus eryngii (Agaricomycetes), from Italy. Int J Med Mushrooms 20(8):717-726. https://doi.org/ 10.1615/intjmedmushrooms.2018027011

Cateni F, Zacchigna M, Procida G et al (2020) Polysaccharides from Pleurotus eryngii var. elaeoselini (Agaricomycetes), a new potential culinary-medicinal oyster mushroom from Italy. Int J Med Mushrooms 22(5):431-444. https://doi.org/ 10.1615/intjmedmushrooms.2020034539
Cayan F, Deveci E, Tel-Cayan G et al (2018) Phenolic acid profile of six wild mushroom species by HPLC-DAD. Chem Nat Compd 54(5):985-986. https://doi.org/10.1007/ s10600-018-2529-2

Cerigini E, Palma F, Barbieri E et al (2008) The Tuber borchii fruiting body-specific protein TBF-1, a novel lectin which interacts with associated Rhizobium species. FEMS Microbiol Lett 284:197-203. https://doi.org/10.1111/j. 1574-6968.2008.01197.x

Chaturvedi VK, Agarwal S, Gupta KK et al (2018) Medicinal mushroom: boon for therapeutic applications. 3 Biotech 8(8):334. https://doi.org/10.1007/s13205-018-1358-0

Chen SY, Ho KJ, Hsieh YJ et al (2012) Contents of lovastatin, $\gamma$ aminobutyric acid and ergothioneine in mushroom fruiting bodies and mycelia. LWT Food Sci Technol 47:274-278. https://doi.org/10.1177/1934578x1100600207

Chen HP, Zhao ZZ, Li ZH et al (2018) Anti-proliferative and anti-inflammatory lanostane triterpenoids from the polish edible mushroom Macrolepiota procera. J Agric Food Chem 66:3146-3154. https://doi.org/10.1021/acs.jafc. 8b00287.s002

Cheung PCK (2013) Mini-review on edible mushrooms as source of dietary fiber: preparation and health benefits. Food Sci Hum Wellness 2:162-166. https://doi.org/10. 1016/j.fshw.2013.08.001

Citores L, Ragucci S, Ferreras JM et al (2019) Ageritin, a ribotoxin from popular mushroom (Agrocybe aegerita) with defensive and antiproliferative activities. ACS Chem Biol 14(6):1319-1327. https://doi.org/10.1021/ acschembio.9b00291.s001

Corrêa RCG, Brugnari T, Bracht A et al (2016) Biotechnological, nutritional and therapeutic uses of Pleurotus spp. (Oyster mushroom) related with its chemical composition: a review on the past decade findings. Trends Food Sci Tech 50(4):103-117. https://doi.org/10.1016/j.tifs.2016.01.012

Costa R, Tedone L, De Grazia S et al (2013) Multiple headspace-solid-phase microextraction: an application to quantification of mushroom volatiles. Anal Chim Acta 770:1-6. https://doi.org/10.1016/j.aca.2013.01.041

Costa R, De Grazia S, Grasso E et al (2015) Headspace-solidphase microextraction-gas chromatography as analytical methodology for the determination of volatiles in wild mushrooms and evaluation of modifications occurring during storage. J Anal Methods Chem 2015:Article ID 951748, 10 pp. https://doi.org/10.1155/2015/951748

D’Auria M, Rana GL, Racioppi R et al (2012) Studies on volatile organic compounds of Tuber borchii and Tuber asa-foetida. J Chromatogr Sci 50:775-778. https://doi.org/ 10.1093/chromsci/bms060

De Felice S (1989) The nutraceutical revolution: fueling a powerful. New International Market

Dewick PM (2009) Medicinal natural products: a biosynthetic approach, 3rd edn. Wiley, Chichester. https://doi.org/10. 1021/jm901204h

Ding Z, Lu Y, Lu Z et al (2010) Hypoglycaemic effect of comatin, an antidiabetic substance separated from Coprinus comatus broth, on alloxan-induced-diabetic rats. Food Chem 121:39-43. https://doi.org/10.1016/j.foodchem. 2009.12.001

Ding X, Hou Y, Hou W et al (2015) Structure elucidation and anti-tumor activities of water-soluble oligosaccharides 
from Lactarius deliciosus (L. ex Fr.) Gray. Pharmacogn Mag 11(44):716-723. https://doi.org/10.4103/0973-1296. 165559

Diyabalanage T, Mulabagal V, Mills G et al (2008) Healthbeneficial qualities of the edible mushroom, Agrocybe aegerita. Food Chem 108:97-102. https://doi.org/10.1016/ j.foodchem.2007.10.049

Dulay RMR, Sanguesa KB, Ablaza JLT et al (2015) Bioactive myco-nutrients of aseptically cultured fruiting bodies of Coprinus comatus (O.F. Müll.) Pers. on rice bran-enriched ruminants' dung. IJBPAS 4(4):1896-1908

Ergönül PG, Ergönül B, Kalyoncu F et al (2012) Fatty acid compositions of five wild edible mushroom species collected from Turkey. Int J Pharmacol 8(5):463-466. https:// doi.org/10.3923/ijp.2012.463.466

Erjavec J, Kos J, Ravnikar M et al (2012) Proteins of higher fungi-from forest to application. Trends Biotechnol 30:259-273. https://doi.org/10.1016/j.tibtech.2012.01.004

Feeney MJ, Miller AM, Roupas P (2014) Mushrooms-biologically distinct and nutritionally unique. Nutr Today 49:301-307. https://doi.org/10.1097/nt. 0000000000000063

Feng T, Li ZH, Dong ZJ et al (2011) Non-isoprenoid botryane sesquiterpenoids from basidiomycete Boletus edulis and their cytotoxic activity. Nat Prod Bioprospect 1:29-32. https://doi.org/10.1007/s13659-011-0005-9

Fernandes A, Barros L, Barreira JCM et al (2013) Effects of different processing technologies on chemical and antioxidant parameters of Macrolepiota procera wild mushroom. LWT Food Sci Technol 54:493-499. https://doi.org/10. 1016/j.1wt.2013.06.027

Fernandes A, Barreira JCM, Antonio AL et al (2015) Exquisite wild mushrooms as a source of dietary fiber: analysis in electron-beam irradiated samples. LWT -Food Sci Technol 60:855-859. https://doi.org/10.1016/j.lwt.2014.10.050

Ferreira ICFR, Barros LL, Abreu RMV (2009) Antioxidants in wild mushrooms. Curr Med Chem 16:1543-1560. https:// doi.org/10.2174/092986709787909587

Fleming A (1929) On the antibacterial action of cultures of a Penicillium, with special reference to their use in the isolation of B. influenzae. Br J Exp Pathol 10:226-236. https:// doi.org/10.1093/clinids/2.1.129

Fogarasi M, Socaci SA, Dulf FV et al (2018) Bioactive compounds and Volatile Profiles of Five Transylvanian Wild Edible Mushrooms. Molecules 23:3272-3286. https://doi. org/10.3390/molecules23123272

Fontana S, Flugy A, Schillaci O et al (2014) In vitro antitumor effects of the cold-water extracts of Mediterranean species of genus Pleurotus (Higher Basidiomycetes) on human colon cancer cells. Int J Med Mushrooms 16(1):49-63. https://doi.org/10.1615/intjmedmushr.v16.i1.50

Fu Z, Liu Y, Zhang Q (2016) A potent pharmacological mushroom: Pleurotus eryngii. Fungal Genom Biol 6(1):1000139. https://doi.org/10.4172/2165-8056. 1000139

Gaglio R, Guarcello R, Venturella G et al (2019) Microbiological, chemical and sensory aspects of bread supplemented with different percentages of the culinary mushroom Pleurotus eryngii in powder form. Int J Food Sci Technol 54:1197-1205. https://doi.org/10.1111/ijfs. 13997
Gallotti F, Lavelli R (2020) The effect of UV irradiation on vitamin D2 content and antioxidant and antiglycation activities of mushrooms. Foods 9:1087. https://doi.org/10. 3390/foods 9081087

Gargano ML, van Griensven LJL, Isikhuemhen OS et al (2017) Medicinal mushrooms: valuable biological resources of high exploitation potential. Plant Biosyst 151(3):548-565. https://doi.org/10.1080/11263504.2017.1301590

Gasecka M, Mleczek M, Siwulski M et al (2016) Phenolic and flavonoid content in Hericium Erinaceus, Ganoderma Lucidum and Agrocybe aegerita under selenium addition. Acta Aliment 45(2):300-308. https://doi.org/10.1556/066. 2016.45.2.18

Giavasis I (2014) Bioactive fungal polysaccharides as potential functional ingredients in food and nutraceuticals. Curr Opin Biotechnol 26:162-173. https://doi.org/10.1016/j. copbio.2014.01.010

Gil-Ramirez A, Pavo-Caballero C, Baeza E et al (2016) Mushrooms do not contain flavonoids. J Funct Foods 25:1-13. https://doi.org/10.1016/j.jff.2016.05.005

Golak-Siwulska I, Kalużewicz A, Spiżewski T et al (2018) Bioactive compounds and medicinal properties of Oyster mushrooms (Pleurotus sp.). Folia Hort 30(2):191-201. https://doi.org/10.2478/fhort-2018-0012

Grangeia C, Heleno SA, Barros LL et al (2011) Effects of trophism on nutritional and nutraceutical potential of wild edible mushrooms. Food Res Int 44:1029-1035. https:// doi.org/10.1016/j.foodres.2011.03.006

Grothe T, Stadler M, Koepcke B et al (2013) Terpenoids spiro ketal compounds with lxr agonists activity, theiruse and formulation with them. U.S. Pat. Appl. Publ. US 20130338219 A1 20131219

Gründemann C, Reinhardt JK, Lindequist U (2020) European medicinal mushrooms: do they have potential for modern medicine? An update. Phytomedicine 66:153131. https:// doi.org/10.1016/j.phymed.2019.153131

Harki E, Bouya D, Dargent R (2005) Maturation-associated alterations of the biochemical characteristics of the black truffle Tuber melanosporum Vitt. Food Chem 99:394-400

Hasnat MA, Pervin M, Debnath T et al (2014) DNA protection, total phenolics and antioxidant potential of the mushroom Russula virescens. J Food Biochem 38:6-17. https://doi. org/10.1111/jfbc. 12019

He P, Li F, Huang L et al (2016) Chemical characterization and antioxidant activity of polysaccharide extract from spent mushroom substrate of Pleurotus eryngii. J Taiwan Inst Chem Eng 69:48-53. https://doi.org/10.1016/j.jtice.2016. 10.017

Heleno SA, Barros LL, Sousa MJ et al (2011) Targeted metabolites analysis in wild Boletus species. LWT Food Sci Technol 2011(44):1343-1348. https://doi.org/10.1016/ j.lwt.2011.01.017

Heleno SA, Ferreira RC, Antonio AL et al (2015) Nutritional value, bioactive compounds and antioxidant properties of three edible mushrooms from Poland. Food Biosci 11:48-55. https://doi.org/10.1016/j.fbio.2015.04.006

Helrich K (1990) Association of Official Analytical Chemists, Official methods of analysis. $15 \mathrm{edn}$. Arlington, VA

Hess J, Wang Q, Gould T et al (2018) Impact of Agaricus bisporus mushroom consumption on gut health markers in 
healthy adults. Nutrients 10:1402. https://doi.org/10.3390/ nu10101402

Hou Y, Liu L, Ding X et al (2016) Structure elucidation, proliferation effect on macrophage and its mechanism of a new heteropolysaccharide from Lactarius deliciosus Gray. Carbohydr Polym 152:648-657. https://doi.org/10.1016/j. carbpol.2016.07.064

Hou Y, Wang M, Zhao D et al (2019) Effect on macrophage proliferation of a novel polysaccharide from Lactarius deliciosus (L. ex Fr.) Gray. Oncol Lett 17(2):2507-2515. https://doi.org/10.3892/ol.2018.9879

Hu Q, Du H, Ma G et al (2018) Purification, identification and functional characterization of an immunomodulatory protein from Pleurotus eryngii. Food Funct 9(7):3764-3775. https://doi.org/10.1039/c8fo00604k

Islam T, Ganesan K, Xu B (2019) New insight into mycochemical profiles and antioxidant potential of edible and medicinal mushrooms: a review. Int J Med Mushrooms 21(3):237-251. intjmedmushrooms.2019030079

Ismaya WT, Tjandrawinata RR, Rachmawati H (2020) Lectins from the edible mushroom Agaricus bisporus and their therapeutic potentials. Molecules 25:2368. https://doi.org/ $10.3390 /$ molecules 25102368

Itonori S, Aoki K, Sugita M (2004) Glycosphingolipids in edible fungi and their biological activities. Foods Food Ingredients J Jpn 209(3):211-218

Jaworska G, Pogoń K, Skrzypczak A (2015) Composition and antioxidant properties of wild mushrooms Boletus edulis and Xerocomus badius prepared for consumption. J Food Sci Technol 52(12):7944-7953. https://doi.org/10.1007/ s13197-015-1933-x

Jeon SM, Bok SH, Jang MK et al (2001) Antioxidative activity of naringin and lovastatin in high cholesterol-fed rabbits. Life Sci 69(24):2855-2866. https://doi.org/10.1016/s00243205(01)01363-7

Jiang X, Teng S, Wang X et al (2018) The antidiabetic and antinephritic activities of Tuber melanosporum via modulation of Nrf2-mediated oxidative stress in the $\mathrm{db} / \mathrm{db}$ mouse. Oxid Med Cell Longev 2018:7453865. https://doi. org/10.1155/2018/7453865

Jing N, Shi J, Li G et al (2012) Determination of fatty acids from mushrooms using high performance liquid chromatography with fluorescence detection and online mass spectrometry. Food Res Int 48:155-163. https://doi.org/10. 1016/j.foodres.2012.02.014

Jing H, Li J, Zhang J et al (2018) The antioxidative and antiaging effects of acidic- and alkali-extractable mycelium polysaccharides by Agrocybe aegerita (Brig.) Sing. Int J Biol Macromol 106:1270-1278. https://doi.org/10.1016/j. ijbiomac.2017.08.138

Kakon AJ, Choudhury MBK, Shusmita S (2012) Mushroom is an ideal food supplement. J Dhaka Natl Med Coll Hos 18:58-62. https://doi.org/10.3329/jdnmch.v18i1.12243

Kalač P (2009) Chemical composition and nutritional value of European species of wild growing mushrooms: a review. Food Chem 113:9-16. https://doi.org/10.1016/j.foodchem. 2008.07.077

Kalač P (2012) A review of chemical composition and nutritional value of wild-growing and cultivated mushrooms.
J Sci Food Agric 93:209-218. https://doi.org/10.1016/j. foodchem.2008.07.077

Kalaras MD, Richie JP, Calcagnotto A (2017) Mushrooms: a rich source of the antioxidants ergothioneine and glutathione. Food Chem 233:429-433. https://doi.org/10. 1016/j.foodchem.2017.04.109

Kalogeropoulos N, Yanni AE, Koutrotsios G et al (2013) Bioactive microconstituents and antioxidant properties of wild edible mushrooms from the island of Lesvos, Greece. Food Chem Toxicol 55:378-385. https://doi.org/10.1016/j. fct.2013.01.010

Khatun S, Islam A, Cakicioglu U (2015) Nutritional qualities and antioxidant activity of three edible oyster mushrooms (Pleurotus spp.). NJAS-Wagen J Life Sc 72-73:1-5. https://doi.org/10.1016/j.njas.2012.03.003

Khaund P, Joshi SR (2014) Enzymatic profiling of wild edible mushrooms consumed by the ethnic tribes of India. J Korean Soc Appl Biol Chem 57(2):263-271. https://doi. org/10.1007/s13765-013-4225-Z

Khider M, Seoudi O, Abdelaliem YF (2017) Functional processed cheese spreads with high nutritional value as supplemented with fresh and dried mushrooms. Int J Food Sci Nutr 6(1):2327-2716. https://doi.org/10.11648/j.ijnfs. 20170601.18

Kikuchi T, Motoyashiki N, Yamada T et al (2017) Ergostanetype sterols from King Trumpet Mushroom (Pleurotus eryngii) and their inhibitory effects on Aromatase. Int $\mathrm{J}$ Mol Sci 18:2479-2489. https://doi.org/10.3390/ ijms 18112479

Kikuchi T, Kitaura K, Katsumoto A et al (2018) Three bisabolane-type sesquiterpenes from edible mushroom Pleurotus eryngii. Fitoterapia 129:108-113. https://doi.org/10. 1016/j.fitote.2018.06.021

Kikuchi T, Isobe M, Uno S et al (2019) Strophasterols E and F: rearranged ergostane-type sterols from Pleurotus eryngii. Bioorg Chem 89:103011. https://doi.org/10.1016/j.bioorg. 2019.103011

Kim YJ, Jung IK, Kwak EJ (2010) Quality characteristics and antioxidant activities of cookies added with Pleurotus eryngii powder. Korean J Food Sci Technol 42(2):183-189

Kim SH, Lee J, Heo Y et al (2016) Effect of Pleurotus eryngii mushroom $\beta$-glucan on quality characteristics of common wheat pasta. J Food Sci 81(4):C835-C840

Kivrak I, Kivrak S, Harmandar M (2014) Free amino acid profiling in the giant puffball mushroom (Calvatia gigantea) using UPLC-MS/MS. Food Chem 158:88-92. https:// doi.org/10.1016/j.foodchem.2014.02.108

Kosanić M, Ranković B, Rančić A et al (2016) Evaluation of metal concentration and antioxidant, antimicrobial, and anticancer potentials of two edible mushrooms Lactarius deliciosus and Macrolepiota procera. J Food Drug Anal 24:477-484. https://doi.org/10.1016/j.jfda.2016.01.008

Koutrotsios G, Kalogeropoulos N, Stathopoulos P et al (2017) Bioactive compounds and antioxidant activity exhibit high intraspecific variability in Pleurotus ostreatus mushrooms and correlate well with cultivation performance parameters. World J Microbiol Biotechnol 33:98. https://doi.org/ 10.1007/s11274-017-2262-1

Kozarski MS, Klaus AS, Niksic MP et al (2014) Polysaccharides of higher fungi: biological role, structure and antioxidative 
activity. Chem Ind 68:305-320. https://doi.org/10.2298/ hemind $121114056 \mathrm{k}$

Kumar K (2015) Role of edible mushrooms as functional foods-a review. South Asian J Food Technol Environ 1(3-4):211-218

Kumar K, Barmanray A (2007) Nutritional evaluation and storage studies of button mushroom powder fortified biscuits. Mushroom Res 16(1):31-35

Kumar S, Pandey AK (2013) Chemistry and biological activities of flavonoids: an overview. Sci World J, Article ID 162750. https://doi.org/https://doi.org/10.1155/2013/162750

Kurt A, Gençcelep H (2018) Enrichment of meat emulsion with mushroom (Agaricus bisporus) powder: impact on rheological and structural characteristics. J Food Eng 237:128-136. https://doi.org/10.1016/j.jfoodeng.2018.05. 028

La Guardia M, Venturella G, Venturella F (2005) On the chemical composition and nutritional value of Pleurotus taxa growing on umbelliferous plants (Apiaceae). J Agric Food Chem 53:5997-6002. https://doi.org/10.1021/ jf0307696

Landi N, Pacifico S, Ragucci S et al (2017a) Pioppino mushroom in southern Italy: an undervalued source of nutrients and bioactive compounds. J Sci Food Agric 97:5388-5397. https://doi.org/10.1002/jsfa.8428

Landi N, Pacifico S, Ragucci S et al (2017b) Purification, characterization and cytotoxicity assessment of Ageritin: the first ribotoxin from the basidiomycete mushroom Agrocybe aegerita. Biochim Biophys Acta 1861:1113-1121. https://doi.org/10.1016/j.bbagen.2017. 02.023

Lavelli V, Proserpio C, Gallotti F et al (2018) Circular reuse of bio-resources: the role of Pleurotus spp. in the development of functional foods. Food Funct 9:1353-1372. https:// doi.org/10.1039/c7fo01747b

Leal AR, Barros LL, Barreira JCM et al (2013) Portuguese wild mushrooms at the "pharma-nutrition" interface: Nutritional characterization and antioxidant properties. Food Res Int 50:1-9. https://doi.org/10.1016/j.foodres.2012.10. 012

Lee SR, Lee D, Lee HJ et al (2017) Renoprotective chemical constituents from an edible mushroom, Pleurotus cornucopiae in cisplatin-induced nephrotoxicity. Bioorg Chem 71:67-73. https://doi.org/10.1016/j.bioorg.2017.01.012

Lee H, Nam K, Zahra Z, Farooqui MQU (2020) Potentials of truffles in nutritional and medicinal applications: a review. Fungal Biol Biotechnol 7:9. https://doi.org/10.1186/ s40694-020-00097-x

Li S, Shah NP (2016) Characterization, antioxidative and bifidogenic effects of polysaccharides from Pleurotus eryngii after heat treatments. Food Chem 197:240-249. https://doi. org/10.1016/j.foodchem.2015.10.113

Li B, Lu F, Suo X et al (2010) Antioxidant properties of cap and stipe from Coprinus comatus. Molecules 15:1473-1486. https://doi.org/10.3390/molecules 15031473

Li HJ, Chen HY, Fan LL et al (2015) In vitro antioxidant activities and in vivo anti-hypoxic activity of the edible mushroom Agaricus bisporus (Lange) Sing. Chaidam Mol 20:17775-17788. molecules 201017775
Li X, Zhang X, Ye L et al (2019) LC-MS-Based Metabolomic approach revealed the significantly different metabolic profiles of five commercial truffle species. Front Microbiol 10:2227. https://doi.org/10.3389/fmicb.2019.02227

Li H, Wang X, Xiong Q et al (2020) Sulfated modification, characterization, and potential bioactivities of polysaccharide from the fruiting bodies of Russula virescens. Int $\mathrm{J}$ Biol Macromol 154:1438-1447. https://doi.org/10.1016/j. ijbiomac.2019.11.025

Liang Y, Chen Y, Liu H et al (2011) The tumor rejection effect of protein components from medicinal fungus. Biomed Prev Nutr 1:245-254. https://doi.org/10.1016/j.bionut. 2011.06.006

Lin S, Ching LT, Lam K et al (2017) Anti-angiogenic effect of water extract from the fruiting body of Agrocybe aegerita. LWT Food Sci Technol 75:155-163. https://doi.org/10. 1016/j.lwt.2016.08.044

Liping S, Xuejiao S, Yongliang Z (2016) Preparation, characterization and antiglycation activities of the novel polysaccharides from Boletus sinicus. Int J Biol Macromol 92:607-614. https://doi.org/10.1016/j.ijbiomac.2016.07. 014

Liu Y, Zhao Y, Yang Y et al (2013) Structural characteristics and hypoglycemic activity of polysaccharides from $\mathrm{Co}$ prinus comatus. Bioact Carbohydr Dietary Fibre 2:164-169. https://doi.org/10.1016/j.bcdf.2013.10.001

Liu W, Yu G, Yu W et al (2017) Autophagy inhibits apoptosis induced by Agrocybe aegerita lectin in hepatocellular carcinoma. Anti-Cancer Agent ME 17(2):221-229. https:// doi.org/10.2174/1871520616666160404112645

Liu G, Ye J, Li W et al (2020a) Extraction, structural characterization, and immunobiological activity of ABP Ia polysaccharide from Agaricus bisporus. Int J Biol Macromol 162:975-984. https://doi.org/10.1016/j.ijbiomac. 2020.06.204

Liu X, Zhang Z, Xu L et al (2020b) Dioscorea saponin transforms the structure of truffle exo-polysaccharide and enhances its antioxidant activity. LWT Food Sci Technol 127:109417. https://doi.org/10.1016/j.lwt.2020.109417

Liu X, Liu D, Chen Y et al (2020c) Physicochemical characterization of a polysaccharide from Agrocybe aegirita and its anti-ageing activity. Carbohydr Polym 236:116056. https://doi.org/10.1016/j.carbpol.2020.116056

Lu X, Brennan MA, Serventi L et al (2016) How the inclusion of mushroom powder can affect the physicochemical characteristics of pasta. Int J Food Sci Technol 51:2433-2439. https://doi.org/10.1111/ijfs. 13246

Lu X, Brennan MA, Serventi L et al (2018) Addition of mushroom powder to pasta enhances the antioxidant content and modulates the predictive glycaemic response of pasta. Food Chem 264:199-209. https://doi.org/10.1016/j. foodchem.2018.04.130

Lu X, Brennan MA, Narciso J et al (2020) Correlations between the phenolic and fibre composition of mushrooms and the glycaemic and textural characteristics of mushroom enriched extruded products. LWT Food Sci Technol 118:108730. https://doi.org/10.1016/j.lwt.2019.108730

Luo A, Luo A, Huang J et al (2012) Purification, characterization and antioxidant activities in vitro and in vivo of the polysaccharides from Boletus edulis Bull. Molecules 
17:8079-8090.

molecules 17078079

https://doi.org/10.3390/

Ma G, Yang W, Zhao L et al (2018) A critical review on the health promoting effects of mushrooms nutraceuticals. Food Sci Hum Well 7:125-133. https://doi.org/10.1016/j. fshw.2018.05.002

Manach C, Scalbert A, Morand C et al (2004) Polyphenols: Food sources and bioavailability. Am J Clin Nutr 79:727-747. https://doi.org/10.1093/ajcn/79.5.727

Matei E, Louis JM, Jee JG et al (2011) NMR solution structure of a cyanovirin homolog from wheat head blight fungus. Proteins 79:1538-1549. https://doi.org/10.1002/prot. 22981

Minato K, Ohara A, Mizuno M (2017) A proinflammatory effect of the $\beta$-glucan from Pleurotus cornucopiae mushroom on macrophage action. Mediat Inflamm 17:8402405/18402405/9. https://doi.org/10.1155/2017/8402405

Mitsou EK, Saxami G, Stamoulou E et al (2020) Effects of rich in B-glucans edible mushrooms on aging gut microbiota characteristics: an in vitro study. Molecules 25:2806. https://doi.org/10.3390/molecules25122806

Motoshima RA, da Rosa T, F, da C Mendes L, et al (2018) Inhibition of Leishmania amazonensis arginase by fucogalactan isolated from Agrocybe aegerita mushroom. Carbohydr Polym 201:532-538. https://doi.org/10.1016/j. carbpol.2018.08.109

Nagy M, Socaci S, Tofanã M et al (2017) Chemical composition and bioactive compounds of some wild edible mushrooms. Bull UASVM Food Sci Technol 74(1):1. https://doi.org/10. 15835/buasvmen-fst:12629

Nowacka N, Nowak R, Drozd M et al (2014) Analysis of phenolic constituents, antiradical and antimicrobial activity of edible mushrooms growing wild in Poland. LWT Food Sci Technol 59:689-694. https://doi.org/10.1016/j.1wt.2014. 05.041

Nowak R, Nowacka-Jechalke N, Juda M et al (2018) The preliminary study of prebiotic potential of Polish wild mushroom polysaccharides: the stimulation effect on Lactobacillus strains growth. Eur J Nutr 57:1511-1521. https://doi.org/10.1007/s00394-017-1436-9

Nowakowski P, Naliwajko SK, Markiewicz-Zukowska R et al (2020) The two faces of Coprinus comatus-functional properties and potential hazards. Phytother Res. https://doi. org/10.1002/ptr.6741

Nuhu A, Nam YK, Gyun SP et al (2011) Antioxidant, phenolic compounds concentration, xanthine oxidase and tyrosinase inhibitory activities of Pleurotus cornucopiae. Aust J Basic Appl Sci 5(3):229-239

Oguri S (2020) Pleurotus cornucopiae mycelial lectin (PCL-M): purification and detection of the activity on mycelial surface. Methods Mol Biol 2132:445-2452. https://doi.org/ 10.1007/978-1-0716-0430-4_43

Oloke JK, Adebayo EA (2015) Effectiveness of immunotherapies from oyster mushroom (Pleurotus species) in the management of immunocompromised patients. Int $\mathrm{J}$ Immunol 3(2-1):8-20. https://doi.org/10.11648/j.iji.s. 2015030201.12

Öztürk M, Duru ME, Kivrak S et al (2011) In vitro antioxidant, anticholinesterase and antimicrobial activity studies on three Agaricus species with fatty acid compositions and iron contents: a comparative study on the three most edible mushrooms. Food Chem Toxicol 49:1353-1360. https:// doi.org/10.1016/j.fct.2011.03.019

Palacios I, Lozano M, Moro C et al (2011) Antioxidant properties of phenolic compounds occurring in edible mushrooms. Food Chem 128:674-678. https://doi.org/10.1016/ j.foodchem.2011.03.085

Palazzolo E, Gargano ML, Venturella G (2012) The nutritional composition of selected wild edible mushrooms from Sicily (southern Italy). Int J Food Sci Nutr 63(1):79-83. https://doi.org/10.3109/096374866.2011.598850

Papoutsis K, Grasso S, Menon A et al (2020) Recovery of ergosterol and vitamin D2 from mushroom waste-Potential valorization by food and pharmaceutical industries. Trends Food Sci Technol 99:351-366. https://doi.org/10. 1016/j.tifs.2020.03.005

Parmar R, Kumar D (2015) Study of chemical composition in wild edible mushroom Pleurotus cornucopiae (Paulet) from Himachal Pradesh, India by using Fourier transforms infrared spectrometry (FTIR), Gas chromatography-mass spectrometry (GCMS) and X-ray fluorescence (XRF). Biol Forum 7(2):1057-1066

Patel Y, Naraian R, Singh VK (2012) Medicinal properties of Pleurotus species (Oyster mushroom): a review. World J Fungal Plant Biol 3(1):1-12

Patel S, Rauf A, Khan H et al (2017) Potential health benefits of natural products derived from truffles: a review. Trends Food Sci Technol 70:1-8. https://doi.org/10.1016/j.tifs. 2017.09.009

Peintner U, Schwarz S, Mesic A et al (2013) Mycophilic or mycophobic? Legislation and guidelines on wild mushroom commerce reveal different consumption behaviour in European countries. PLoS ONE 8(15):e63926. https://doi. org/10.1371/journal.pone.0063926

Pelaes Vital AC, Goto PA, Hanai LN et al (2015) Microbiological, functional and rheological properties of low fat yogurt supplemented with Pleurotus ostreatus aqueous extract. LWT Food Sci Technol 64:1028-1035. https://doi. org/10.1016/j.lwt.2015.07.003

Petrović J, Glamočlija J, Stojković D et al (2015) Nutritional value, chemical composition, antioxidant activity and enrichment of cream cheese with chestnut mushroom Agrocybe aegerita (Brig.) Sing. J Food Sci Technol 52(10):6711-6718. https://doi.org/10.1007/s13197-0151783-6

Pietrzak-Fiećko R, Galgowska M, Bakula S (2016) Fatty acid composition in wild Boletus edulis from Poland. Ital J Food Sci 28(3):402-411. https://doi.org/10.14674/1120-1770/ ijfs.v42

Pirillo A, Capatano AL (2014) Nutraceuticals: definitions, European regulations and clinical applications (Nutraceutica: definizione, regolamentazione e applicazioni). Giorn Ital Farmacoecon Farmacoutiliz 6(4):23-30

Pizzoferrato L, Manzi P, Bertocchi F et al (2000) Solid state ${ }^{13} \mathrm{C}$ CP MAS NMR spectroscopy of mushrooms gives directly the ratio between proteins and polysaccharides. J Agric Food Chem 48:5484-5488. https://doi.org/10.1021/ jf000448j

Poniedziałek B, Siwulski M, Wiater A et al (2019) The effect of mushroom extracts on human platelet and blood coagulation: in vitro screening of eight edible species. Nutrients 11:3040. https://doi.org/10.3390/nu11123040 
Popović M, Vukmirović S, Stilinović N et al (2010) Anti-oxidative activity of an aqueous suspension of commercialpreparation of the mushroom Coprinus comatus. Molecules 15:4564-4571. https://doi.org/10.3390/ molecules 15074564

Proserpio C, Lavelli V, Laureati M et al (2019) Effect of Pleurotus ostreatus powder addition in vegetable soup on B-glucan content, sensory perception, and acceptability. Food Sci Nutr 7:730-737. https://doi.org/10.1002/fsn3.917

Punelli F, Reverberi M, Porretta D et al (2009) Molecular characterization and enzymatic activity of laccases in two Pleurotus spp. with different pathogenic behaviour. Mycol Res 113:381-387. https://doi.org/10.1016/j.mycres.2008. 11.018

Rathore H, Prasad S, Sharma S (2017) Mushroom nutraceuticals for improved nutrition and better human health: a review. PharmaNutrition 5:35-46. https://doi.org/10.1016/j.phanu. 2017.02.001

Reis FS, Martins A, Barros LL et al (2012) Antioxidant properties and phenolic profile of the most widely appreciated cultivated mushrooms: a comparative study between in vivo and in vitro samples. Food Chem Toxicol 50:1201-1207. https://doi.org/10.1016/j.fct.2012.02.013

Reis FS, Martins A, Vasconcelos MH et al (2017) Functional foods based on extracts or compounds derived from mushrooms. Trends Food Sci Technol 66:48-62. https:// doi.org/10.1016/j.tifs.2017.05.010

Ren XM, Li DF, Jiang S et al (2015) Structural basis of specific recognition of non-reducing terminal $\mathrm{N}$-acetylglucosamine by an Agrocybe aegerita lectin. PLoS ONE 10(6):e0129608/1-e0129608/15. https://doi.org/10.2210/ pdb4tqk/pdb

Reverberi M, Di Mario F, Tomati U (2004) $\beta$-Glucan synthase induction in mushrooms grown on olive mill wastewaters. Appl Microbiol Biotechnol 66:217-225. https://doi.org/10. 1007/s00253-004-1662-y

Rodrigues DMF, Freitas AC, Rocha-Santos TAP et al (2015) Chemical composition and nutritive value of Pleurotus citrinopileatus var cornucopiae, P. eryngii, P. salmoneo stramineus, Pholiota nameko and Hericium erinaceus. J Food Sci Technol 52(11):6927-6939. https://doi.org/10. 1007/s13197-015-1826-Z

Ruggiero A, García-Ortega L, Ragucci S et al (2018) Structural and enzymatic properties of Ageritin, a novel metal-dependent ribotoxin-like protein with antitumor activity. BBA-Gen Subj 1862:2888-2894. https://doi.org/10.1016/ j.bbagen.2018.09.010

Ruthes AC, Smiderle FR, Iacomini M (2015) D-Glucans from edible mushrooms: a review on the extraction, purification and chemical characterization approaches. Carbohydr Polym 117:753-761. https://doi.org/10.1016/j.carbpol. 2014.10.051

Salehi F (2019) Characterization of different mushrooms powder and its application in bakery products: a review. Int $\mathrm{J}$ Food Prop 22(1):1375-1385. https://doi.org/10.1080/ 10942912.2019.1650765

Sande D, de Oliveira GP, Fidelis de Moura MA et al (2019) Edible mushrooms as a ubiquitous source of essential fatty acids. Food Res Int 125:108524. https://doi.org/10.1016/j. foodres.2019.108524
Sarma D, Saha AK, Datta BK (2018) Bioactive compounds with special references to anticancer property of oyster mushroom Pleurotus ostreatus. J Pharmacogn Phytochem 7(4):2694-2698

Schillaci D, Arizza V, Gargano ML, Venturella G (2013) Antibacterial activity of Mediterranean Oyster mushrooms, species of genus Pleurotus (Higher Basidiomycetes). Int J Med Mushrooms 15(6):591-594. https:// doi.org/10.1615/IntJMedMushr.v15.i6.70

Selvamani S, El-Enshasy HA, Dailin DJ et al (2018) Antioxidant compounds of the edible mushroom Pleurotus ostreatus. Int J Biotechnol Wellness Ind 7:1-14. https:// doi.org/10.6000/1927-3037.2018.07.01

Singla R, Ghosh M, Ganguli A (2009) Phenolics and antioxidant activity of a ready-to-eat snack food prepared from the edible mushroom (Agaricus bisporus). Nutr Food Sci 39(3):227-234. https://doi.org/10.1108/ 00346650910957474

Smiderle FR, Ruthes AC, van Arkel J (2011) Polysaccharides from Agaricus bisporus and Agaricus brasiliensis show similarities in their structures and their immunomodulatory effects on human monocytic THP-1 cells. BMC Complem Altern Med 11:58. https://doi.org/10.1186/1472-6882-1158

Souilem F, Fernandes Â, Calhelha RC et al (2017) Wild mushrooms and their mycelia as sources of bioactive compounds: Antioxidant, anti-inflammatory and cytotoxic properties. Food Chem 230:40-48. https://doi.org/10. 1016/j.foodchem.2017.03.026

Srikram A, Supapvanich S (2016) Proximate compositions and bioactive compounds of edible wild and cultivated mushrooms from Northeast Thailand. Agric Nat Resour 50:432-436. https://doi.org/10.1016/j.anres.2016.08.001

Stojković D, Reis FS, Glamoclija JM et al (2014) Cultivated strains of Agaricus bisporus and A. brasiliensis: chemical characterization and evaluation of antioxidant and antimicrobial properties for the final healthy productnatural preservatives in yoghurt. Food Funct 5(7):1602-1612. https://doi.org/10.1039/c4fo00054d

Stojković D, Reis FS, Ciric A et al (2015) Boletus aereus growing wild in Serbia: chemical profile, in vitro biological activities, inactivation and growth control of food-poisoning bacteria in meat. Int $\mathbf{J}$ Food Sci Technol 52(11):7385-7392. https://doi.org/10.1007/s13197-0151853-9

Su S, Ding X, Fu L et al (2019) Structural characterization and immune regulation of a novel polysaccharide from Maerkang Lactarius deliciosus Gray. Int J Mol Med 44(2):713-724. https://doi.org/10.3892/ijmm.2019.4219

Sun YX, Liu JC, Yang XD et al (2010a) Purification, structural analysis and hydroxyl radical-scavenging capacity of a polysaccharide from the fruiting bodies of Russula virescens. Process Biochem 45:874-879. https://doi.org/10. 1016/j.procbio.2010.02.007

Sun Z, Zhang L, Zhang B et al (2010b) Structural characterisation and antioxidant properties of polysaccharides from the fruiting bodies of Russula virescens. Food Chem 118:675-680. https://doi.org/10.1016/j.foodchem.2009. 05.036

Surup F, Hennicke F, Sella N (2019) New terpenoids from the fermentation broth of the edible mushroom Cyclocybe 
aegerita. Beilstein J Org Chem 15:1000-1007. https://doi. org/10.3762/bjoc. 15.98

Tala MF, Qin J, Ndongo JT et al (2017) New azulene-type sesquiterpenoids from the fruiting bodies of Lactarius deliciosus. Nat Prod Bioprospect 7:269-273. https://doi. org/10.1007/s13659-017-0130-1

Talkad MS, Das RK, Bhattacharjee P et al (2015) Establishment of enzyme inhibitory activities of lovastatin, isolated from Pleurotus ostreatus. Int J Appl Sci Biotechnol 3(3):408-416. https://doi.org/10.3126/ijasbt.v3i3.12932

Taofiq O, González-Paramás AM, Martins A et al (2016) Mushrooms extracts and compounds in cosmetics, cosmeceuticals and nutricosmetics - a review. Ind Crop Prod 90:38-48. https://doi.org/10.1016/j.indcrop.2016.06.012

Tejedor-Calvo E, Morales D, Marco P et al (2020) Screening of bioactive compounds in truffles and evaluation of pressurized liquid extractions (PLE) to obtain fractions with biological activities. Food Res Int 132:109054. https://doi. org/10.1016/j.foodres.2020.109054

Tsai YS, Huang SJ, Mau JL (2006) Antioxidant properties of hot water extracts from Agrocybe cylindracea. Food Chem 98:670-677. https://doi.org/10.1016/j.foodchem.2005.07. 003

Tsai SY, Tsai HL, Mau JL (2007) Nutritional value, chemical composition, antioxidant activity and enrichment of cream cheese with chestnut mushroom Agrocybe aegerita (Brig.) Sing. (Agaricomycetideae). Int $\mathrm{J}$ Med Mushrooms 9:47-55. https://doi.org/10.1007/s13197-015-1783-6

Tsai SY, Huang SJ, Lo SH et al (2009) Flavour components and antioxidant properties of several cultivated mushrooms. Food Chem 113:578-584. https://doi.org/10.1016/j. foodchem.2008.08.034

Valverde ME, Hernández-Pérez T, Paredes-López O (2015) Edible Mushrooms: improving human health and promoting quality life. Int J Microbiol Article ID 376387:14 pp. https://doi.org/10.1155/2015/376387

Vanamu E (2012) In vitro antimicrobial and antioxidant activities of ethanolic extract of lyophilized mycelium of Pleurotus ostreatus PQMZ91109. Molecules 17:3653-3671. https://doi.org/10.3390/ molecules 17043653

Venturella G, Palazzolo E, Saiano F et al (2015) Notes on a new productive strain of king oyster mushroom, Pleurotus eryngii (higher Basidiomycetes), a prized Italian culinarymedicinal mushroom. Int $\mathrm{J}$ Med Mushrooms 17(2):199-206. intjmedmushrooms.v17.i2.110

Venturella G, Saporita P, Gargano ML (2019) The potential role of medicinal mushrooms in the prevention and treatment of gynecological cancers: a review. Int J Med Mushrooms 21(3):225-235. intjmedmushrooms.2019030289

Verma NK, Singh AP, Singh VK (2019) Agaricus bisporus (Fungi): chemical constituents and pharmacological activities-a review. AJPCR 7(2):82-87

Vetter J (2003) Data on sodium content of common edible mushrooms. Food Chem 81(4):589-593. https://doi.org/ 10.1016/s0308-8146(02)00501-0

Villares A, García-Lafuente A, Guillamón E et al (2012) Identification and quantification of ergosterol and phenolic compounds occurring in Tuber spp. Truffles J Food
Compos Anal 26:177-182. https://doi.org/10.1016/j.jfca. 2011.12.003

Vita F, Taiti C, Pompeiano A et al (2015) Volatile organic compounds in truffle (Tuber magnatum Pico): comparison of samples from different regions of Italy and from different seasons. Sci Rep 5:12629. https://doi.org/10.1038/ srep12629

Vita F, Lucarotti V, Alpi E et al (2017) Proteins from Tuber magnatum Pico fruiting bodies naturally grown in different areas of Italy. Proteome Sci 11:7. https://doi.org/10.1186/ 1477-5956-11-7

Vita F, Franchina FA, Taiti C et al (2018) Environmental conditions influence the biochemical properties of the fruiting bodies of Tuber magnatum Pico. Sci Rep 8:7243. https:// doi.org/10.1038/s41598-018-25520-7

Wang S, Marcone MF (2011) The biochemistry and biological properties of the world's most expensive underground edible mushroom: Truffles. Food Res Int 44:2567-2581. https://doi.org/10.1016/j.foodres.2011.06.008

Wang S, Bao L, Han J et al (2013a) Pleurospiroketals A-E, Perhydrobenzannulated 5,5-Spiroketal sesquiterpenes from edible mushroom Pleurotus cornucopiae. J Nat Prod 76:45-50. https://doi.org/10.1021/np3006524

Wang S, Bao L, Zhao F et al (2013b) Isolation, identification, and bioactivity of monoterpenoids and sesquiterpenoids from the mycelia of edible mushroom Pleurotus cornucopiae. J Agric Food Chem 61:5122-5129. https://doi.org/ 10.1016/j.foodchem.2013.11.062

Wang D, Sun SQ, Wu WZ et al (2014a) Characterization of a water-soluble polysaccharide from Boletus edulis and its antitumor and immunomodulatory activities on renal cancer in mice. Carbohydr Polym 105:127-134. https://doi. org/10.1016/j.carbpol.2013.12.085

Wang L, Zhang R, Ma Z et al (2014b) A feruloyl esterase (FAE) characterized by relatively high thermostability from the edible mushroom Russula virescens. Appl Biochem Biotech 172(2):993-1003. https://doi.org/10.1007/s12010013-0536-0

Wang XM, Zhang J, Wu LH et al (2014c) A mini-review of chemical composition and nutritional value of edible wildgrown mushroom from China. Food Chem 151:279-285. https://doi.org/10.1016/j.foodchem.2013.11.062

Wani BA, Bodha RH, Wani AH (2010) Nutritional and medicinal importance of mushrooms. J Med Plant Res 4(24):2598-2604. https://doi.org/10.5897/jmpr09.565

Wasser SP (2014) Medicinal mushroom science: current perspectives, advances, evidences, and challenges. Biomed J 37:345-356. https://doi.org/10.4103/2319-4170.138318

Weijn A, Van den Berg-Somhorst DBPM, Slootweg JC et al (2013) Main phenolic compounds of the melanin biosynthesis pathway in bruising-tolerant and bruising-sensitive buttom mushroom (Agaricus bisporus) strains. J Agric Food Chem 61:8224-8231. https://doi.org/10.1021/ jf4020558

Wu X, Huang C, Chen Q et al (2014) A novel laccase with inhibitory activity towards HIV-I reverse transcriptase and antiproliferative effects on tumor cells from the fermentation broth of mushroom Pleurotus cornucopiae. Biomed Chromatogr 28:548-553. https://doi.org/10.1002/bmc. 3068 
Xiao Y, Chen L, Fan Y et al (2019) The effect of boletus polysaccharides on diabetic hepatopathy in rats. ChemBiol Interact 308:61-69. https://doi.org/10.1016/j.cbi. 2019.05.013

$\mathrm{Xu} \mathrm{Z,} \mathrm{Fu} \mathrm{L,} \mathrm{Feng} \mathrm{S} \mathrm{et} \mathrm{al} \mathrm{(2019)} \mathrm{Chemical} \mathrm{composition,}$ antioxidant and antihyperglycemic activities of the wild Lactarius deliciosus from China. Molecules 24:1357. https://doi.org/10.3390/molecules24071357

Yang Q, Yin Y, Pan Y et al (2018) Anti-metastatic activity of Agrocybe aegerita galectin (AAL) in a mouse model of breast cancer lung metastasis. J Funct Foods 41:163-170. https://doi.org/10.1016/j.jff.2017.12.058

Yap H-YY, Tan N-H, Ng S-T et al (2018) Inhibition of protein glycation by tiger milk mushroom [Lignosus rhinoceros (Cooke) Ryvarden] and search for potential anti-diabetic activity-related metabolic pathways by genomic and transcriptomic data mining. Front Pharmacol 9:103. https://doi. org/10.3389/fphar.2018.00103

Yeh CW, Kan SC, Lin CC et al (2016) Polyhydroxylated steroids and triterpenoids from an entophytic fungus, Hypocreales sp. NCHU01 isolated from Tuber magnatum. J Taiwan Inst Chem E 64:22-30. https://doi.org/10.1016/j. jtice.2016.03.049

Yilmaz N, Türkekul I, Bulut S et al (2013) Fatty acid composition in ten mushroom species collected from middle black sea region of Turkey. Asian J Chem 25(3):1216-1220. https://doi.org/10.14233/ajchem.2013.12599a

Zhang Y, Mills GL, Nair MG (2003) Cyclooxygenase inhibitory and antioxidant compounds from the fruiting body of an edible mushroom, Agrocybe aegerita. Phytomedicine 10:386-390. https://doi.org/10.1078/0944-7113-00272

Zhang A, Xiao N, He P et al (2011) Chemical analysis and antioxidant activity in vitro of polysaccharides extracted from Boletus edulis. Int J Biol Macromol 49:1092-1095. https://doi.org/10.1016/j.ijbiomac.2011.09.005

Zhang J, Ma Z, Zheng L et al (2014) Purification and antioxidant activities of intracellular zinc polysaccharides from Pleurotus cornucopiae SS-03. Carbohydr Polym 111:947-954. https://doi.org/10.1016/j.carbpol.2014.04.074
Zhang JJ, Li Y, Zhou T et al (2016) Bioactivities and health benefits of mushrooms mainly from China. Molecules 21:938. https://doi.org/10.3390/molecules21070938

Zhang L, Hu Y, Duan X et al (2018) Characterization and antioxidant activities of polysaccharides from thirteen boletus mushrooms. Int J Biol Macromol 113:1-7. https:// doi.org/10.1016/j.ijbiomac.2018.02.084

Zhao YY, Shen X, Chao X et al (2011) Ergosta-4,6,8(14),22tetraen-3-one induces $\mathrm{G} 2 / \mathrm{M}$ cell cycle arrest and apoptosis in human hepatocellular carcinoma HepG2 cells. Biochim Biophy Acta Gen Subj 4:384-390. https://doi.org/10.1016/ j.bbagen.2010.12.005

Zhao H, Li H, Lai Q et al (2019) Antioxidant and hepatoprotective activities of modified polysaccharides from Coprinus comatus in mice with alcohol-induced liver injury. Int $\mathrm{J}$ Biol Macromol 127:476-485. https://doi.org/10.1038/ s41598-018-30104-6

Zheng S, Li C, Ng TB et al (2007) A lectin with mitogenic activity from the edible wild mushroom Boletus edulis. Process Biochem 42:1620-1624. https://doi.org/10.1016/j. procbio.2007.09.004

Zhou S, Liu Y, Yang Y et al (2013) Separation and structural elucidation of a polysaccharide $\mathrm{CC} 30 \mathrm{w}-1$ from the fruiting body of Coprinus comatus. Bioact Carbohydr Dietary Fibre 1:99-104. https://doi.org/10.1016/j.bcdf.2013.03.003

Zhu MJ, Du F, Zhang GQ et al (2013) Purification a laccase exhibiting dye decolorizing ability from an edible mushroom Russula virescens. Int Biodeterior Biodegrad 82:33-39. https://doi.org/10.1016/j.ibiod.2013.02.010

Žurga S, Nanut MP, Kos J et al (2017) Fungal lectin MpL enables entry of protein drugs into cancer cells and their subcellular targeting. Oncotarget 8(16):26896-26910. https://doi.org/10.18632/oncotarget.15849

Publisher's Note Springer Nature remains neutral with regard to jurisdictional claims in published maps and institutional affiliations. 